Nixt-8201-No 1151

\author{
A dynamic simulation model \\ for growth of the African catfish, \\ Clarias gariepinus (Burchell 1822)
}


Promotor : dr. E.A. Huisman, hoogleraar in de visteelt en visserij Co-promotor: dr. F.W.T. Penning de Vries, visiting scientist IRRI, Manila, Philippijnen 


\title{
NNO8201,1151
}

\author{
M.A.M. Machiels
}

\section{A dynamic simulation model for growth of the African catfish, Clarias gariepinus (Burchell 1822)}

\author{
Proefschrift \\ ter verkrijging van de graad van \\ doctor in de landbouwwetenschappen. \\ op gezag van de rector magnificus, \\ dr. C.C. Oosterlee, \\ in het openbaar te verdedigen \\ op vrijdag 19 juni 1987 \\ des namiddags te vier uur in de aula \\ van de Landbouwuniversiteit te Wageningen
}

BIBLIOTHEEK

EANDBOUWUNIVERSTTEIT

WAGENINGEN

$15 N 488138$ 
Machiels. M.A.M., 1987. A dynamic simulation model for growth of the African catfish. Clarias gariepinus (Burchell 1822). Dissertation, Agricultural University, Wageningen. The Netherlands. 


$$
1,192701,101
$$

STELLINGEN

Kwantificeren van de stofwisseling op basis van fundamentele biochemische reacties is efficiënter dan op basis van gegevens verzameld met dierexperimenten,

- De behoefte van vis aan essentiële aminozuren kan berekend worden uit zijn lichaamssamenstelling.

D.M. Gatlin, 1987. Aquaculture, 60: 223-229.

Meervaltelers kunnen de opbrengst verhogen door de vissen mager te houden.

dit proefschrift

Bij vissen heeft selectie op groei de voorkeur boven selectie op een betere voederbenutting.

B. Kinghorn, 1983. Aquaculture, 32: 141-155.

b. Voeropname is slechts indirect afhankelijk van de energie-inhoud van het voer.

dit proefschrift

5. Ter aanvuliing van magledigingsmodellen, verdient het aanbeveling de maagvuliingssnelheid bij vissen te bepalen.

7. Dubbel overplanten van rijst biedt meer mogelijkheden voor visteelt in rijstvelden.

8. Sinds er geen marsmuziek meer door de luidsprekers van de voetbalvelden klinkt, is het supportersgeweld sterk toegenomen.

9. Als de bodemerosie van het Zuidlimburgse landschap in het huidige tempo doorgaat, kunnen de boeren aldaar binnen 20 jaar, zonder noemenswaardige investeringen, overgaan tot de mergelwinning.

10. Hoe meer meerval, hoe meer prijsval.

Proefschrift van M.A.M. Machiels

A dynamic simulation model for growth of the African catfish, Clarias gariepinus (Burchell 1822)

19 juni 1987.

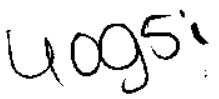


Aan mijn ouders 
VOORWOORD

Dit proefschrift is het resultaat van een onderzoek dat uitgevoerd is in het kader van een driejarig promotieassistentschap bij de vakgroep Visteelt en Visserij van de Landbouwuniversiteit in samenwerking met de vakgroep Theoretisch Teeltkunde van dezelfde instelling. Het onderzoek heb ik kunnen afronden door de hulp en intensieve begeleiding van een groot aantal mensen.

Mijn promotor prof. dr. Bram Huisman dank ik voor het vertrouwen dat hij in mij heeft gesteld door te stimuleren dat ik met het hier beschreven onderzoek zou beginnen. Ook heeft hij veel bijgedragen aan het leesbaar maken van de verschillende manuscripten.

Mijn Co-promotor dr. Frits Penning de Vries ben ik erkentelijk voor zijn grote bijdrage die hij vanaf het prilste begin aan dit onderzoek heeft geleverd. De kritische wijze waarop hij de manuscripten heeft doorgenomen heb $i k$ erg gewaardeerd.

De andere begeleiders, dr. ir. André Henken en prof. dr. ir. Rudi Rabbinge, hebben ieder op hun eigen wijze gezorgd voor een uitstekende begeleiding bij de uitvoering van het onderzoek.

Dr. ir. Herre Hogendoorn heeft mijn belangstelling voor het verschijnsel visgroei opgewekt. Ik ben hem dankbaar voor de stimulatie om op dit pad door te gaan en de ondersteuning bij dit onderzoek. Bij het samenstellen en de bereiding van de vele verschillende voeders, heb ik veel medewerking van de firma Trouw en Co. ontvangen. Ik wil hiervoor speciaal ir. Wout Dekker bedanken.

Bij dit onderzoek is gebruik gemaakt van het werk en de hulp van een aantal doctoraal studenten. Met name ir. Anne van Dam, ir. 0lga Haenen, ir. Marga van der Schaft, Bert Schuilenburg, ir. Mark Spekenbrink en ir. Willem Rotman wil ik danken voor hun inzet en de fijne samenwerking.

Verder wil ik de medewerkers van de betrokken vakgroepen, de medewerkers van de proefaccommodatie "De Haar vissen" en alle anderen die niet met name genoemd zijn, bedanken voor hun bijdragen aan dit proefschrift. 


\section{CONTENTS}

General introduction 1

I. Effect of feeding level on growth and energy meta- 7 bolism

II. Effect of feed composition on growth and energy metabol ism

III. The effect of body composition on growth and feed intake

IV. The effect of feed formulation on growth and feed utilization

General discussion

Summary 
GENERAL INTRODUCTION

In a few regions of the world aquaculture, the farming and husbandry of fresh water and marine organisms, started at the same time as animal husbandry and arable crop farming (Milne, 1972; Boguchi and Grygiel. 1983). The progress of aquaculture in time is somewhat different from the other agricultural practices. While today, the yield of meat and arable crops originates almost completely from agriculture. aquaculture counts for around $10 \mathrm{million}$ metric tons of the total world aquatic yield of 85 million tons (estimation for 1983). The world aquaculture production will rise to 26 million tons by the end of the century, meeting the expected future shortfall in supply of fisheries (Jones, 1986). To achieve this, aquaculture must become a growing modern industry, incorporating new technologies and following the example set by the progress over the past decades of some other agricultural practices.

The world aquaculture is mainly concentrated in Asia and Europe. The contribution of the African continent to the world production is negligible ( $\pm 0.1 \%$ ) (Huisman and Machiels, 1986). Tilapia is a most widely used species in African aquaculture (Balarin and Hutton. 1979). However, the high management requirement for this species are difficult to meet. Therefore, studies were carried out during the early seventies to identify other (then Tilapia species) promising aquacultural candidate species within the African region. In the course of these studies the suitability of the "air breathing" African catfish Clarias gariepinus (Burchel1 1822) was recognized (Micha, 1973). The requisite conditions for a suitable species for fish culture (Huet, 1972) are met by this fish. C. gariepinus is an omnivorous fish species which is highly appreciated as a table fish in the region. Atmospheric oxygen is made available to the fish through its arborescent organ and, therefore. low oxygen concentration in the water are not critical, enabling high stocking densities.

Over the past 10 years research at the Department of Fish culture and Fisheries of the Agricultural University in Wageningen, the Netherlands, has concentrated on $\underline{C}$. gariepinus in three major biological disciplines reproduction, nutrition and health control. From a production viewpoint the reproduction of $\mathrm{C}$. gariepinus can be controlled at present (Huisman, 1986). By artificial reproduction it is now possible to 
have reliable supply of fry and fingerlings. Once reproduction problems are solved, one of the major research fields in fish culture focusses on growth, which determines the success of the enterprise to a great extent. The production can only be optimised if sufficient expertise on how growth is affected by nutritional factors (e.g. feed quantity and quality) and environmental circumstances (like climate and water quality) is available.

A fish during the fattening process can be regarded as a conversion unit that converts less valuable feed commodities into a high quality food product. This asks for production strategies to maximize profitability according to changes in costs of feed stuffs and returns from marketed fish. In an extensive culture system C. gariepinus feeds on naturally occurring feeds like zooplankton. insects and other animal prey (Clay, 1979). In more intensive culture systems the natural food is no longer adequate for growth and it is necessary to supplement it with fish feed. Ultimately in a highly intensive culture system the fish feeds on a complete diet because natural food is no longer available.

The yield is the net outcome of a series of physiological and behavioral processes in a system, beginning with food intake and terminating in deposition of body substances. The complicated relationships in such a system can be simplified by developing a model, which also may improve our knowledge on relevant biological processes. Simulation techniques provide us with estimates of production results to be achieved using various combination of nutrient inputs and other management operations.

Similar as animal production, earlier models in fish culture research relating growth to feed intake, use a bioenergetical approach. Pioneering work on this subject has been done by Pütter (1909;1920). Von Bertalanffy (1957) and Beverton and Holt (1957). Bioenergetic growth models are based on the thermodynamic principle of conservation of energy. Starting with the energy balance equation, growth is regarded as the net result of energy entering respectively leaving the body. The physiological background of the Von Bertalanffy growth model relates a change in weight to the net result of anabolism and catabolism. Anabolism is proportional to the resorption capacity of the intestine surface. The catabolism is proportional to the volume of the fish. Recently, growth models for culture fish are developed by Hogen- 
doorn et al. (1983) for C. gariepinus and by from and Rasmussen (1984) for rainbow trout, Salmo gairneri. In both models growth of a single fish was formulated as a first order non-linear differential equation. The original Von Bertalanffy (1957) growth equation, which was taken as starting point, is:

$$
\mathrm{dW} / \mathrm{dt}=\mathrm{H} \cdot \mathrm{W}^{m}-D \cdot \mathrm{W}^{n}
$$

where $H$ and $D$ are coefficients of rate of anabolism and catabolism and $W=$ body weight $(m=2 / 3, n=1)$.

The relation between input and output in these models is found by fitting the overall function. The values of the included parameters are determined using statistical procedures. The models rely on the results of large scale experiments, where production characteristics like weight gain, feed conversion and body composition are related to combinations of feed intake levels, fish size and temperature regimes. In these models the fish itself is regarded as a black box which converts energy. Such models only superficially take into account the biological mechanisms in the growth process, but are very useful describing experimental data. The values of parameters used in such relations are only representative for the conditions prevailing in the experimental setup. Therefore, these descriptive models have restricted applicability. The model of Hogendoorn et al. (1983) can predict growth of . gariepinus at a given size and at a given combination of temperature and feed ration. This has resulted in recommended feeding levels in relation to body size and temperature over the experimental range. If the feed composition is changed the model is no longer valid, and experiments have to be repeated for adjustment of the model.

An other way to analyze this conversion unit is to "open" it, in order to assess the convertor itself. The results of such an approach are not derived from one particular set of data, but from reliable theories or hypotheses on the functioning of the biological system. Such models, having an explanatory character, are mathematical forms derived from facts and insights about the structure and the behaviour of a system (De Wit, 1982). In biology, different levels of organization are distinguished, which may be classified to the size of a system (e. g. cells; individuals; ecosystems). Models, which are meant to be explanatory, allow the understanding of larger systems on the basis of knowledge of smaller systems. Thus, the functioning of an individual can be understood if one knows the functioning of the composite cells 
and organs. The parameters in an explanatory model can be interpreted biologically, because the model takes into account underlying forces and mechanisms. However, it should be reminded that also explanatory models have descriptive aspects, but the degree can vary over a wide range. The more explanatory a model is, the better it provides a projection over a great domain and thus can be used outside the range of experimental data. Dynamic models are simplified representations of systems that change in time. Part of such dynamic models may be formed by static models. An example of a static model is a model that calculates the efficiency of a biosynthesis reaction.

The general objective of this thesis is developing a dynamic explanatory growth model to understand how growth is affected by nutrition, feed ration and environmental factors like temperature. This objective can be achieved by analyzing as far as possible the underlying mechanisms that determine and control growth, i.e. the intermediate metabolism and biochemistry. For this purpose the performance of the body is described by basic biochemical reactions.

The development, the formulation of the functions, the calibration and the validation of the model is discussed in the next chapters.

\section{REFERENCES}

Balarin, J.D. and Hatton, J.P.. 1979. Tilapia: A guide to their biology and culture in Africa. Univ. Stirling. Scotland, $174 \mathrm{pp}$.

Beverton, R.J.H. and Holt, S.J.. 1957, On the dynamics of exploited fish populations. Fishery Invest.. Lond. Ser. II vol. XX 533 pp. Bogucki, P. and Grygiel, R., 1983. Early farmers on the North European Plain. Scientific American, 248(4) 104-108.

Clay, D., 1979. Population biology, growth and feeding of the African catfish (Clarias gariepinus) with special reference to juveniles and their importance in fish culture. Arch. Hydrobiol. 87, 453-482. De Wit, C.Y., 1982. Simulation of living systens. In: F.W.T. Penning de Vries and H.H. Van Laar (Editors), Simulation of plant growth and crop production. (Simulation Monographs) Pudoc, Wageningen, pp. 3-8. 
From, J. and Rasmussen, G., 1984. A growth model, gastric evacuation and body composition in rainbow trout. Salmo gairdneri Richardson, 1836. Dana. 3: 61-139.

Hogendoorn, H., Jansen, J.A.J., Koops, W.J.. Machiels, M.A.M., Van Ewijk, P.H. and Van Hees, J.P., 1983. Growth and production of the African catfish, Clarias lazera (C.\& V.). II effects of body weight. temperature and feeding level in intensive tank culture. Aquaculture, 34: 265-285.

Huet, M., 1972. Textbook of fish culture. Fishing News (Books) Ltd.. London. 436 pp.

Huisman. E.A., 1986. The aquacultural potential of the African catfish (Clarias garieginus, Burche11, 1822). In: E.A. Huisman (Editor), Aquaculture research in the African Region. Pudoc, Wageningen. pp 175-188 Huisman, E.A. and Machiels, M.A.M., 1986. Fish production for food in the tropics. In: T.G. Taylor and N.K. Jenkins (Ėditors), Proc. XIIIth International Congress on Nutrition. Brighton, UK, August 1985. John libbey, London-Paris. pp. 892-896.

Jones, A., 1986. Historical background, present status, and future perspectives of the aquaculture industry on a worldwide basis. In: J.G. Balchen and A. Tyssö. Preprints of the IFAC symposium on automation and data processing in aquaculture. August 1986. Trondheim, Norway. A:1-9. Micha, J. -C.. 1973. Etude des populations piscicoles de l'Ubangui et tentatives de sélectior et d'adaption de quelques especes a l'étang de pisciculture. C.T.F.T., Paris, 110 pp.

Milne, P.H., 1972. Fish and shellfish farming in coastal waters. Fishing News (Books) Ltd.. London. 208 pp.

Pütter, A., 1909. Die Ernährung der Fische. Zeitschrift für allgemeine Physiologie, Jena XIX: 147-242.

Pütter, A., 1920. Studien über physiologische Xhnlichkeit. VI. Wachstumsähnlichkeiten. Pflügers Arch. Gesamte Physiol. Menschen Tiere, 179 180: $298-340$.

Von Bertalanffy, L., 1957. Quantitative laws on metabolism and growth. Quarter. Rev. Biol. 32(3): 217-231. 


\title{
A Dynamic Simulation Model for Growth of the African Catfish, Clarias gariepinus (Burchell 1822) ${ }^{1}$ \\ I. Effect of Feeding Level on Growth and Energy Metabolism
}

\author{
M.A.M. MACHIELS and A.M. HENKEN \\ Department of Fish Culture and Fisheries, Agricultural University, P.O. Box 338, Wageningen \\ (The Netherlands)
}

(Accepted 22 May 1986)

\begin{abstract}
Machiels, M.A.M. and Henken, A.M., 1986. A dynamic simulation model for growth of the African catfish, Clarias gariepinus (Burchell 1822).I. Effect of feeding level on growth and energy metabolism. Aquaculture, 56: 29-52.
\end{abstract}

To investigate the effect of feeding level on growth of the African catfish a dynamic simulation model was developed. The model can be characterized as explanatory. This means that growth is explained by the processes involving nutrient intake, digestion and absorption, biochemical reactions in the intermediate metabolism and the ultimate deposition of body constituents. In the model these processes are described. After development and parameterization the model was tested with independently obtained data originating from experimental research on the effect of feeding level on growth and energy metabolism of fish of different weight classes, held at different temperatures $\left(20,25\right.$ and $\left.30^{\circ} \mathrm{C}\right)$ and fed with a commercial trout diet. Initial values and input variables used were mean body weight ( $\mathrm{g}$ ) of the fish, fat content (\%) of the fish, feed composition, feeding level $\left(\mathrm{g} \cdot \mathrm{day}^{-1} \cdot \mathrm{fish}^{-1}\right)$ and temperature. Output obtained included daily values of growth, protein gain, fat gain and oxygen consumption.

It is concluded that the model estimates satisfactorily effects of feeding level on growth and energy metabolism of fish at different temperatures. The model is sufficiently general to be applicable to other species after calibration of a few parameters and assumptions. Finally it is shown that more research is needed to determine the maximum attainable growth rate of the African catfish, especially when different dietary compositions are used.

\section{INTRODUCTION}

Growth rate and feed conversion are two major factors determining production results. The amount and quality of the feed administered have a pro-

Clarias gariepinus and Clarias lazera are synonyms for the same species: recently the nomenclature of the genus Clarias has been revised (Teugels, 1984). 
nounced effect on both. To determine the relation between amount of feed and weight gain for different kinds of feed, for different weight classes of fish and for different culture conditions would require many experiments, much effort and a lot of time and money.

To overcome these difficulties, modelling may be helpful. Various growth models have been developed for this purpose (Ricker, 1979). Recent models (Hogendoorn et al., 1983; From and Rasmussen, 1984) are based on the growth concept of Von Bertalanffy (1957) which was more specifically applied to fish by Beverton and Holt (1957). These models can be characterized as descriptive: they "fit" data on the system level to experimental outcomes, demonstrating therefore a relation between input and output. In concept the models have some physiological background. In practice the goodness of fit is the only proven criterion to choose a certain model. These models can only be applied with confidence within a given range of conditions and, more specifically, with data of a similar background to those used to fit the equation.

The objective of the present study was to develop a model which can be characterized as explanatory. An explanatory model is obtained by incorporating the processes which are recognized at underlying organizational levels (De Wit, 1982). This means that growth must then be explained by the processes involving nutrient intake, digestion, metabolism and the composition of body constituents. The quantitative equations of an explanatory model should describe these processes and reflect knowledge of the relationships. The model should also allow extrapolation to production conditions beyond those used to fit the equations. Moreover, the model should show any gaps in the understanding of theoretical and experimental research.

In a series of four publications we will deal with an explanatory model which takes into account various external factors which influence growth: i.e., feeding level, feed composition (the amount of nutrients in the feed), feed formulation (the ingredients used in the feed) and body composition (the condition of the fish to which the feed is offered).

The African catfish, Clarias gariepinus (Burchell, 1822), is used in this study. It is regarded as a promising candidate for aquaculture (Hogendoorn, 1983b). The model was developed using data obtained with this species.

In this first publication attention is focussed on the effect of feeding level on growth and energy metabolism of fish held at three different temperatures (20, 25 and $30^{\circ} \mathrm{C}$ ) and fed with a commercial trout diet (Table 1).

\section{MODEL DERIVATION AND PARAMETERIZATION}

The main elements of the model and their relations are shown in Fig. 1 . The state variable approach is used, based on the use of digital computers. The simulation language is based on the axiom that changes of the conditions of a system are not dependent on each other, but can be derived separately from 
TABLE 1

Feed composition (Trouvit, Trouw \& Co., Putten, The Netherlands)

\begin{tabular}{lc}
\hline & $\%$ \\
\hline Moisture & 9 \\
Crude protein & $48-50$ \\
Crude fat & $7-9$ \\
Crude fibre & $1.5-2.5$ \\
Ash & $8-11$ \\
NFE (Nitrogen-free extract) & $20-23.5$ \\
\hline
\end{tabular}

the state of the system. The state of the system at any moment can be quantified. The rates of change of the state variables are quantified by rate variables. The rate variables can be described by mathematical equations, which are formulated according to knowledge of the underlying processes. The depiction of the simulation model by the relational diagram is done according to the industrial dynamics concept developed by Forrester (1961). In the relational diagram state, rate and driving variables are distinguished. State variables are quantities. Rate variables represent flow of material between state variables. Driving variables are those that are not affected by processes within the system but characterize the influence from outside.

In this model the amounts of the various digested nutrients (amino acids, fatty acids and glucose) determine the amounts of deposited protein and fat. The digestion rate depends on eating rate, diet composition and digestion efficiency. Changes in the amounts of the different body constituents are the result of biosynthesis from absorbed nutrients and metabolic breakdown.

Total metabolic rate is the sum of fasting metabolic rate (routine metabolic rate), feeding metabolic rate (metabolic rate for digestion and various other metabolic expenditures due to feeding) and the metabolic rate for biosynthesis of biomass.

When, apart from the initial body weight, the protein gain is known, fresh weight gain is calculated from the relation between body weight and protein content as given by Hogendoorn (1983a). Fat gain is considered to affect the body composition but not the fresh weight gain. When the fat content increases, the moisture content will decrease and vice versa.

The potential daily growth has an upper limit in order to restrict feed intake. When this maximum value is reached further assimilation is zero. The feed intake stops then.

The computer program developed is presented in Figs. 2 and 3. It is written in CSMP III (Continuous System Modelling Program: IBM, 1975) using a fixed timestep of $1 / 10$ day.

The dynamics of growth within one day are of no interest for a system with 


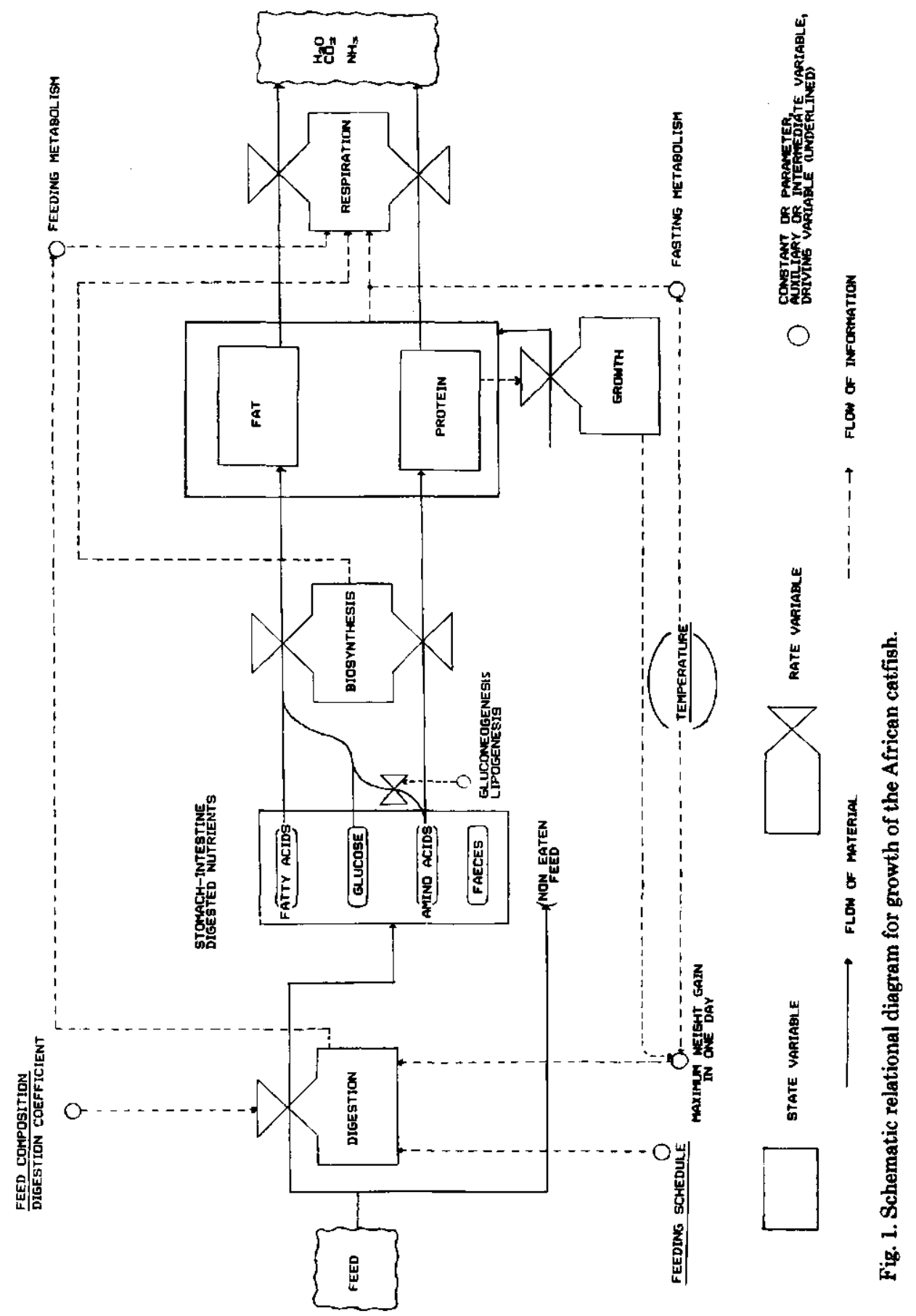

Fig. 1. Schematic relational diagram for growth of the African catfish. 
TITLE DYHAMIC SIMULATIONS OF GROWTH AND FEED UTILIZATION OF CLARIAS P GROWTH PERIOD (DAY)

PARAH NRD : 26

STORAGE FEED $(50)$

HOSORT

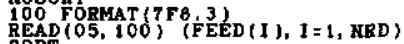

PARAM IWF $=100$, IFAT $=5$

IPRO $=0.13 *$ (1WF**1.057)

PAR FEDCOMPOS T TO ION (Y OF DRY MATTER)

PAR TEMPERATURE (DEGREE CELCIUS)

PARAY TEMPER $=25$

* FEEDING RATE IH G/FISH/DAY

DAYNBR:ZHOLD (IMPULS $(0,0,1,0)$, TIME) +1

YTTDTM=PULSE (TIMFED-DELT IIMPULS STFDTM, 1.01)

TOTFED INTGRL $(0,0$, FEEDAT)

- MAXI HUM GROWTH IN OKE DAY (G)

FUNCTIOK HXGRFN, $20=(0,0),(1,0.04),(2,0.075),(3,0.105),(4,0.13), \ldots$ $(60,0.54),(160 ; 0.6),(200,0.7,140,0.50), \ldots$

FUNCTION MXGRFH, $25=$

$0,0),(1,0.09) ;(2,0), 17\},(3,0.25),(4,0.32), \ldots$

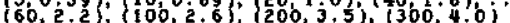

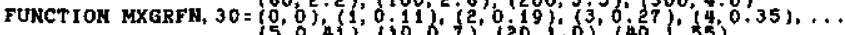
$60,2,1),(100,2,3),(200,3), 25),(300,3,6)$

MAXGRO = TOVAR (MXGRFR, WF, TEMPER) (IMPULS (STFDTM, 1.0), WF)),

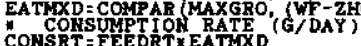

CONSRT = FEEDRT * EATHXD

STOMACEITTGR ( 0.0 , CONSRT-STINRT)

FOODCOMPONEKTS

PARAY DIGCAR=40 DIGPRO=80, DIGFAT $=80$

GLHCST $=$ STOHAC* (FERDCA 100
AMINST

FATSTO $=$ STOMC* (FEDDAA) 100$\}$

STI KRT = CONSRT

PARAAT $=$ (Q10*

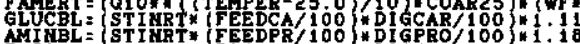

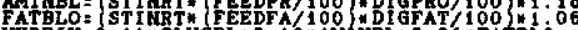

HYDR IM $=0.11 *$ GLUCBL+0.18*AM KBL 0.06 FATELO

FAECPR : INTGRL (O.O. FAECIN

PIOCHEMICAL AEACTION GALANCE

PARA AAFDGL =0 2

GLUGLA =AAFDGL AHIABL:0.53

AAGLAT:-GLUMLA* O 17

GLUBLT $=G L U C B L+G L U B L A$

FAGLEL=GLUBLT\#D.29

FAGLO2=-FAGLEL $\times 0.76$

FAT TO FAT

PAFT OF ASSIHILATED AMINO-ACIDS TO PROTEIM

AAPRSY = AMINALE (1-AAFDGL) *0.9

* FATEAAPRSYW D. OS

PARAN COFD TE $=0.02$

BMMERT: (GLUCBL+ AMIMBL+FATBLO)* COFDHE

RESPIQATIOH RATE (MOLE ATP (DAT)

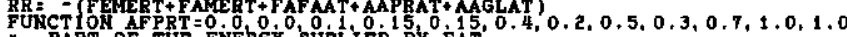
FPRTAAFGEN TAFPRT, FAT/PRO

PRORRT=

FABRT = FATRRT 1096

FABRO2 = FABRRT 2.90
PRBRO2 = PRARTT $1: 45$

O2CORT =-(FABRO2+PRBRO2+FAGLO2+AAGLO2)

$02=\operatorname{INTGRL}(0,0,02$ CORT $)$

NTFART $\stackrel{\text { FA }}{=}$ \GLBL+FATBLO+FABRRT

FAT IITGRL (IFAT, NTFART)

NTPRRT =AAPRSY + PRBRRT

PROE I HTGRL (I PRO, HTPRRT)

* FISH WE GHT (G)

REWF = OPTPRT (WFWF

WF = INTERL (IWF, RWF

TIMER FINT IM : 2 Q., DELT $=0.1$

IHPUT
$\frac{10}{3} .600$
$3: 112$
3
4
?:m

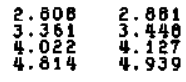
2.956
$3: 538$
4.234
5.068
3.033
$3: 630$
$4: 344$
$\begin{array}{ll}3.021 & 3.920 \\ 4.573 & 4.692\end{array}$
5. 194

ENDI I 457

ETD

Fig. 2. A listing of the CSMP program. 

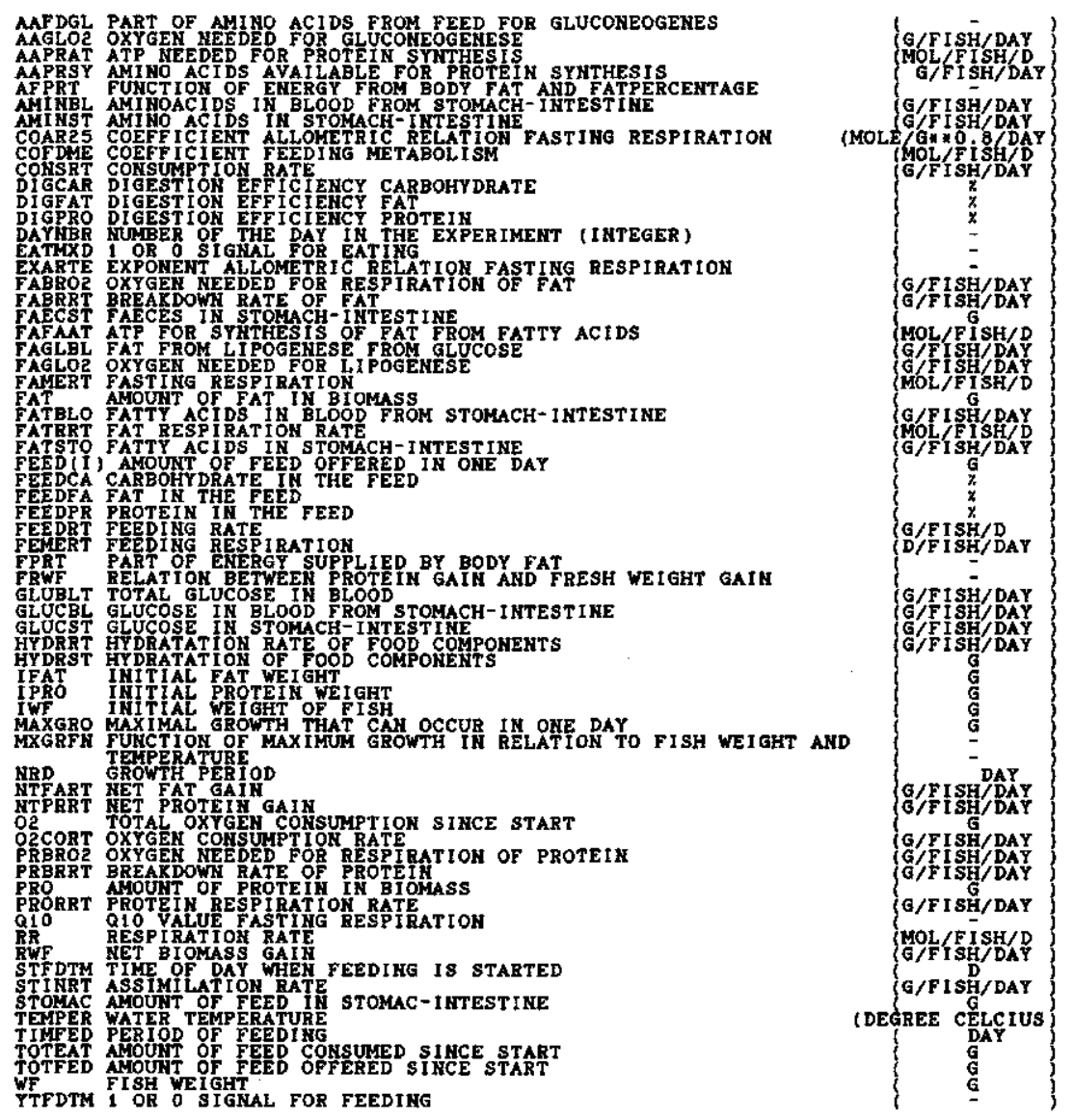

Fig. 3. An explanation of the abbreviations used in the CSMP program as listed in Fig. 2.

a response time of at least one day. All nutrients are supposed to be used for biosynthesis and respiration then. State variables for the amounts of metabolites in the stomach-intestine and the blood are recognized, but serve no purpose for the calculation.

\section{Biochemical pathways in the intermediate metabolism}

A description of the major metabolic pathways of nutrients and body constituents can be found in biochemical handbooks, such as Dagley and Nicholson (1970) or Stryer (1975). Based on these pathways, conversion equations can be made, describing the amount of substrate needed for the formation of any particular end product (Penning de Vries et al., 1974; Schulz, 1978).

In the framework of this model the following assumptions were made:

(1) The amino acid composition of fish and dietary protein was identical to 
the average amino acid composition of Salvelinus protein as given by Love (1970). Variation in amino acid composition between fish species seems to be small (Love, 1980). Dietary protein originates from fish meal.

(2) Tri-oleylglycerol (TOG, $\mathrm{C}_{57} \mathrm{O}_{6} \mathrm{H}_{104}$ ) was chosen as representative for fish and dietary fat. Oleine $\left(\mathrm{C}_{18: 1}\right)$ is the most abundant fatty acid in fish (Love, 1980). Dietary fat is mainly fish oil.

(3) Synthesis of glycogen was neglected, since fish have small glycogen reserves (Love, 1980).

(4) The chemical composition of protein and fat are constant. Moreover, changes in composition of these fractions would also have minor effects on the results (Penning de Vries et al., 1974).

(5) Ammonia is the only nitrogenous excretion product, since fresh water fish excrete nitrogen mainly as ammonia (Forster and Goldstein, 1969).

(6) All nucleotide triphosphates are interconvertible and equally able to transfer energy. In the model ATP was used. The ATP/AMP conversion was replaced by 2 ATP $/ 2$ ADP. The transfer of electrons from NADH to NADP to form NADPH requires 1 mole ATP per mole NADPH formed. The transfer of 1 mole NADH or equivalents from the cytosol into the mitochondria requires 1 mole ATP. The reversed process is free of energy costs. Oxidation of NADH yields 3 ATP (Schulz, 1978).

(7) A cost of 2 mole ATP per mole metabolite involved in the biosynthesis of body constituents was calculated for transportation across biomembranes assuming that all metabolites have to pass two membranes while the transport in between is free (Schulz, 1978).

Based on the description of the major metabolic pathways in the literature and the above-mentioned assumptions, the conversion equations for protein, fat and carbohydrate can be determined.

Protein. To account for hydratation the amount of amino acids (AA, mean mol.weight $=118 \mathrm{~g})$ obtainable from protein $(\mathrm{mol}$. weight $=n \times 100 \mathrm{~g}, n=$ the number of AA) was calculated by multiplying the amount of digestible protein by 1.18 . The three possible metabolic pathways of amino acids are: complete breakdown, , gluconeogenesis and protein synthesis. A summary of complete breakdown and gluconeogenesis is given in Table 2 . The overall equations of the three pathways are:

for complete breakdown

$$
1 \mathrm{AA}+4.6 \mathrm{O}_{2} \rightarrow 4.5 \mathrm{CO}_{2}+1.2 \mathrm{NH}_{3}+2.5 \mathrm{H}_{2} \mathrm{O}+0.03 \mathrm{H}_{2} \mathrm{~S}+24.8 \mathrm{ATP}
$$

for gluconeogenesis

$$
1 \mathrm{AA}+2.5 \mathrm{O}_{2} \rightarrow 2.3 \mathrm{CO}_{2}+1.2 \mathrm{NH}_{3}+0.66 \mathrm{H}_{2} \mathrm{O}+0.35 \text { glucose }+11.2 \mathrm{ATP}
$$




\section{TABLE 2}

Amino acid parameter values for molecular reaction equations of complete breakdown and gluconeogenesis

\begin{tabular}{|c|c|c|c|c|c|c|c|c|c|c|}
\hline \multirow[t]{2}{*}{ No. } & \multirow[t]{2}{*}{ Name } & \multirow{2}{*}{$\begin{array}{l}\text { Mol. } \\
\text { weight } \\
\text { (g) }\end{array}$} & \multicolumn{4}{|c|}{ Complete breakdown } & \multicolumn{4}{|c|}{ Gluconeogenesis } \\
\hline & & & $\begin{array}{l}\mathrm{O}_{2} \\
\text { (mole) } \\
\text { (a) }\end{array}$ & $\begin{array}{l}\mathrm{CO}_{2} \\
\text { (mole) } \\
\text { (b) }\end{array}$ & $\begin{array}{l}\mathrm{NH}_{33} \\
\text { (mole) } \\
\text { (c) }\end{array}$ & $\begin{array}{l}\text { ATP } \\
\text { (mole) } \\
\text { (d) }\end{array}$ & $\begin{array}{l}\mathrm{O}_{2} \\
(\text { mole }) \\
(\mathrm{e})\end{array}$ & $\begin{array}{l}\mathrm{CO}_{2} \\
\text { (mole) } \\
\text { (f) }\end{array}$ & $\begin{array}{l}\text { Glu } \\
\text { (mole) } \\
\text { (g) }\end{array}$ & $\begin{array}{l}\text { ATP } \\
\text { (mole) } \\
\text { (h) }\end{array}$ \\
\hline 1 & ALA & 89 & 3.0 & 3.0 & 1 & 18 & 0.8 & 0.8 & 0.4 & 2.5 \\
\hline 2 & ARG & 174 & 5.5 & 6.0 & 4 & 38 & 2.5 & 3.0 & 0.5 & 18.0 \\
\hline 3 & ASP & 133 & 3.0 & 4.0 & 1 & 18 & 0.7 & 1.7 & 0.4 & 2.5 \\
\hline 4 & ASN & 132 & 3.0 & 4.0 & 2 & 18 & 0.7 & 1.7 & 0.4 & 2.5 \\
\hline 5 & CYS & 121 & 4.0 & 3.0 & 1 & 15 & 2.2 & 1.2 & 0.3 & 2.5 \\
\hline 6 & GLU & 147 & 4.5 & 5.0 & 1 & 27 & 1.5 & 2.0 & 0.5 & 7.0 \\
\hline 7 & GLN & 146 & 4.5 & 5.0 & 2 & 27 & 1.5 & 2.0 & 0.5 & 7.0 \\
\hline 8 & GLY & 75 & 1.5 & 2.0 & 1 & 9 & 0.6 & 1.1 & 0.2 & 2.5 \\
\hline 9 & HIS & 155 & 5.0 & 6.0 & 3 & 30 & 2.0 & 3.0 & 0.5 & 10.0 \\
\hline 10 & ILE & 131 & 7.5 & 6.0 & 1 & 43 & 4.5 & 3.0 & 0.5 & 23.0 \\
\hline 11 & LEU & 131 & 7.5 & 6.0 & 1 & 42 & - & - & - & - \\
\hline 12 & LYS & 146 & 7.0 & 5.5 & 1 & 37 & - & - & - & - \\
\hline 13 & MET & 149 & 7.0 & 5.0 & 1 & 21 & 3.5 & 2.0 & 0.5 & 3.0 \\
\hline 14 & PHE & 165 & 10.0 & 9.0 & 1 & 40 & 7.0 & 6.0 & 0.5 & 21.5 \\
\hline 15 & PRO & 115 & 5.5 & 5.0 & 1 & 32 & 2.5 & 2.0 & 0.5 & 12.0 \\
\hline 16 & HPR & 131 & 5.0 & 5.0 & 1 & 29 & 1.7 & 1.7 & 0.5 & 5.7 \\
\hline 17 & SER & 105 & 2.5 & 3.0 & 1 & 15 & 0.7 & 1.2 & 0.3 & 2.5 \\
\hline 18 & THR & 119 & 4.0 & 4.0 & 1 & 23 & 1.0 & 1.0 & 0.5 & 3.0 \\
\hline 19 & TRP & 204 & 11.5 & 11.5 & 2 & 47 & 8.5 & 8.0 & 0.5 & 26.0 \\
\hline 20 & TYR & 181 & 9.5 & 9.0 & 1 & 44 & 6.5 & 6.0 & 0.5 & 24.0 \\
\hline 21 & VAL & 117 & 6.0 & 5.0 & 1 & 32 & 3.0 & 2.0 & 0.5 & 14.0 \\
\hline
\end{tabular}

Complete breakdown:

$1 \mathrm{AA}+$ (a) $\mathrm{O}_{2} \rightarrow$ (b) $\mathrm{CO}_{2}+$ (c) $\mathrm{NH}_{3}+$ (d) $\mathrm{ATP}$

Gluconeogenesis:

$1 \mathrm{AA}+$ (e) $\mathrm{O}_{2} \rightarrow$ (f) $\mathrm{CO}_{2}$ (c) $\mathrm{NH}_{31}+$ (g) glucose + (h) ATP

for protein synthesis

$1 \mathrm{AA}+6 \mathrm{ATP} \rightarrow 100$ g protein $+1 \mathrm{H}_{2} \mathrm{O}$

The translation of these reaction equations into weights yields:

for complete breakdown

$1 \mathrm{~g} \mathrm{AA}+1.25 \mathrm{~g} \mathrm{O}_{2} \rightarrow 1.70 \mathrm{~g} \mathrm{CO}_{2}+0.17 \mathrm{~g} \mathrm{NH}_{3}+0.38 \mathrm{~g} \mathrm{H}_{2} \mathrm{O}+0.21$ mole ATP

for gluconeogenesis

$1.00 \mathrm{~g} \mathrm{AA}+0.68 \mathrm{~g} \mathrm{O}_{2} \rightarrow 0.86 \mathrm{~g} \mathrm{CO}_{2}+0.17 \mathrm{~g} \mathrm{NH}_{3}+0.12 \mathrm{~g} \mathrm{H}_{2} \mathrm{O}$

+0.53 g glucose +0.095 mole ATP 
for protein synthesis

$1.00 \mathrm{~g} \mathrm{AA}+0.051$ mole ATP $\rightarrow 0.85 \mathrm{~g}$ protein $+0.15 \mathrm{~g} \mathrm{H}_{2} \mathrm{O}$

Fat. Complete breakdown or fat synthesis off fatty acids and glycerol are the two alternatives in fat metabolism. The overall equations are:

for complete breakdown

$1 \mathrm{TOG}+80 \mathrm{O}_{2} \rightarrow 57 \mathrm{CO}_{2}+52 \mathrm{H}_{2} \mathrm{O}+452 \mathrm{ATP}$

for fat synthesis

1 oleine +1 glycerol +12 ATP $\rightarrow 3 \mathrm{H}_{2} \mathrm{O}+1$ TOG

The translation into weights yields:

for complete breakdown

$1 \mathrm{~g} \mathrm{TOG}+2.9 \mathrm{~g} \mathrm{O}_{2} \rightarrow 2.8 \mathrm{~g} \mathrm{CO}_{2}+1.1 \mathrm{~g} \mathrm{H}_{2} \mathrm{O}+0.51$ mole ATP

for fat synthesis

0.96 g oleine +0.10 g glycerol +0.014 mole ATP $\rightarrow 0.06$ g $_{2} \mathrm{O}+1.00 \mathrm{~g}$ TOG

Carbohydrate. To account for hydratation the amount of glucose (mol. weight $=180 \mathrm{~g}$ ) obtainable from starch (mol. weight $=n \times 162 \mathrm{~g}, n=$ the number of single glucose molecules) was calculated by multiplying the amount of digestible carbohydrates by 1.11 . This glucose, together with glucose originating from gluconeogenesis of protein, is only used for fat synthesis. The overall equation is:

16.7 glucose $+20.3 \mathrm{O}_{2} \rightarrow 43.3 \mathrm{CO}_{2}+48.2 \mathrm{H}_{2} \mathrm{O}+1$ TOG

The translation into weights yields:

1 g glucose $+0.22 \mathrm{~g} \mathrm{O}_{2} \rightarrow 0.63 \mathrm{~g} \mathrm{CO}_{2}+0.29 \mathrm{~g} \mathrm{H}_{2} \mathrm{O}+0.29 \mathrm{~g}$ TOG

\section{Total metabolic rate}

Energy needed for respiration is obtained by oxidation of body and/or feed material. This energy is used for:

(1) maintenance of the body, including breakdown and resynthesis of biomass components (turn-over);

(2) transportation of metabolites;

(3) assimilation of nutrients;

(4) muscular activity;

(5) biosynthesis; 
(6) formation and excretion of waste products.

The energy requirements of each process ( 1 to 6 ) separately cannot be determined experimentally.

In fasting conditions the combined processes $1,2,4$ and 6 determine the amount of oxygen consumed. Under those conditions ATP requirements are at a minimum.

When feed is administered, oxygen consumption increases. This increase is partly due to an increase above fasting levels of the processes 1,2, 4 and 6 and partly due to energy requirements for the processes 3 and 5 .

In our model the following strategy was used: ATP requirements for transportation of metabolites and for biosynthesis are accounted for in the biochemical reaction balance; the fraction of the oxygen consumed under feeding conditions above the amount of oxygen consumed under fasting conditions is called feeding metabolism.

Routine metabolic rate. The term routine metabolic rate refers to metabolic rate of fish under fasting conditions while not restricted in spontaneous activity. The intensity of the routine metabolic rate is related to body weight, according to Winberg (1956), following:

$\mathrm{T}=\alpha \cdot \mathrm{W}^{\prime \prime}$

with: $T=$ the rate of energy consumption (mole ATP $\cdot$ day $^{-1}$ )

$W=$ body weight $(\mathrm{g})$

$\alpha=$ rate constant (mole ATP $\cdot \mathrm{g}^{-0.8} \cdot$ day $^{-1}$ )

$\gamma=$ exponent.

The exponent was set at 0.8 as proposed by Winberg (1956) and confirmed for the African catfish (Hogendoorn, 1983a). The rate constant, $\alpha$, was calculated from fat and protein losses of starved fish at 20,25 and $30^{\circ} \mathrm{C}$. At $25^{\circ} \mathrm{C}$ it was found to be 0.0012 mole ATP $\cdot \mathrm{g}^{-0.8}$. $\mathrm{day}^{-1}$, while the $Q_{10}$ value accounting for the thermal effect was 2.0 .

Feeding metabolic rate. The heat increment above routine levels due to feeding was found to be about $15 \%$ of gross energy ingested, irrespective of body weight and meal size in the experiments of Beamish (1974) and Schalles and Wissing (1976). The gross energy content of the feed used by Hogendoorn (1983a) was $22.4 \mathrm{~kJ} \cdot \mathrm{g}^{-1}$. This would give a heat increment of $22.4 \times 0.15=3.36 \mathrm{~kJ} \cdot \mathrm{g}^{-1}$. Using an oxycaloric equivalent of $14.3 \mathrm{~kJ} \cdot \mathrm{g}^{-1} \mathrm{O}_{2}$ (Elliot and Davison, 1975), the increase in oxygen consumption per gram of feed ingested is $0.235 \mathrm{~g} \mathrm{O}_{2}$. From the biochemical reaction balance it was calculated that biosynthesis will cause a respiration of $0.17 \mathrm{~g} \mathrm{O}_{2}$ per gram feed. The remaining $0.065 \mathrm{~g} \mathrm{O}_{2}$ per gram feed ingested was included in the model as 'feeding metabolism'. The kJ equivalent of each mole of ATP derived from any metabolite is $77.3 \mathrm{~kJ} / \mathrm{mole}$. The feeding metabolism amounts to 0.012 mole ATP per gram feed. 
Feed intake and assimilation of nutrients

The amount of feed consumed is the most important factor which determines growth rate. The regulatory mechanisms which control feed intake, however, are not yet fully known, although causal effects have been established for blood glucose levels, fat deposited and stomach evacuation rate (Peter, 1979). In this model the following strategy was used: feed provided was chosen as the driving force for feed intake. To limit intake to a certain maximum, growth attainable in one day was set at the maximum growth observed in experiments. It is a function of fish weight and temperature, when using one type of feed (Hogendoorn et al., 1983).

To account for the difference between consumed and digested nutrients, $20 \%$ of the crude protein and fat intake and $60 \%$ of the intake of nitrogen-free extract was considered to be not digested. These estimates are based on observations of Hogendoorn (1983a) on metabolizability of gross energy at feeding levels sufficiently low to ensure consumption of all the feed administered.

\section{Biosynthesis, growth and biomass composition}

Proximate analysis of fish fed with the trout diet as mentioned in Table 1 showed the dry matter composition to be 60 to $80 \%$ protein and 20 to $25 \%$ fat. Comparing fish and feed composition, it is concluded that some dietary protein is used for gluconeogenesis and lipogenesis. The remaining amino acids are then used for protein synthesis, while fat synthesis is based on dietary fat and lipogenesis. The net protein and fat gain or loss is determined by the difference between anabolism and catabolism. Under fasting conditions, all metabolic energy is obtained by oxidizing body material. The ratio at which body fat and protein are oxidized was arbitrarily set to be dependent on the body composition of the fish in order to avoid unrealistic (=never observed) body compositions (Fig. 4).

When feed is provided, ATP requirements are increased for biosynthesis purposes. Part of these requirements is met by ATP obtained from gluconeogenesis and lipogenesis reactions, the remainder being supplied by oxidizing body material. In the model, metabolites originating from feed are used in the biosynthesis reactions and body material is oxidized to meet the then remaining ATP requirements for the respiration processes.

When protein gain is known, growth is calculated from the relation between body weight and protein content given by Hogendoorn (1983a). Fat gain is considered only to affect body composition, i.e. fat and water content. An argument is found in data presented in Fig. 5.

\section{Parameterization}

Most values of parameters used in the model were derived from the literature. Some had to be calibrated by estimation from experimental data. Data 


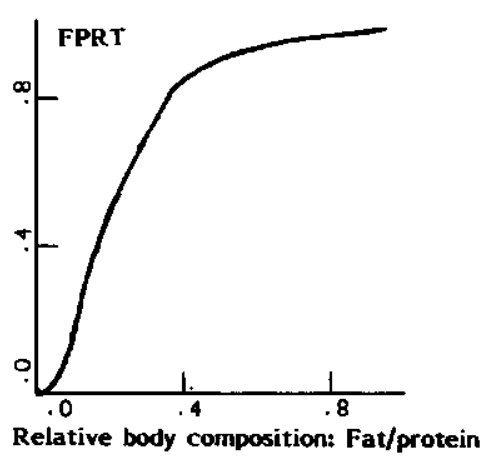

Fig. 4. Relationship between relative body composition (fat/protein) and the part of the respiration energy that is supplied by body fat (FPRT).

from Hogendoorn et al. (1983) were used for calibration of those parameters which were expected to have specific values for the feed and/or species used or which could not be derived from the literature.

Parameters calibrated were:

FAMERT: the rate constant for fasting fish at $25^{\circ} \mathrm{C}(0.0012$ mole ATP. $g^{-0.8} \cdot$ day $^{-1}$ )

Q10: $Q_{10}$ value for routine metabolism as determined in the range from 20 to $30^{\circ} \mathrm{C}(2.0)$

FEMERT: energy used for feeding respiration $\left(0.012\right.$ mole ATP $\cdot \mathrm{g}^{-1}$ feed ingested)

AAFDGL: part of digested amino acids used for gluconeogenesis (20\%)

FPRT: part of energy required that is supplied by oxidation of body fat (see Fig. 4)

MAXGRO: maximum growth attainable in one day (a function of body weight and temperature, see Fig. 2).

The results of the calibration are presented in Figs. 6, 7 and 8. The bisectors represent perfect agreement between observed and simulated growth, protein and fat gain, respectively. In the experiments there were several fishes in each aquarium ( $15 \leq n \leq 250$, depending on the weight of the fishes). Observed values represent the average weight gains of the fishes during the different trials. The broken lines around the bisectors enclose the $95 \%$ confidence interval. The width of this interval is based on the variation between the experimental replications around their mean value. The trials were conducted with two replicates.

\section{DATA USED TO TEST THE MODEL}

To test the validity of the model, simulated output was compared with experimental results not used during the process of model development. Such inde- 


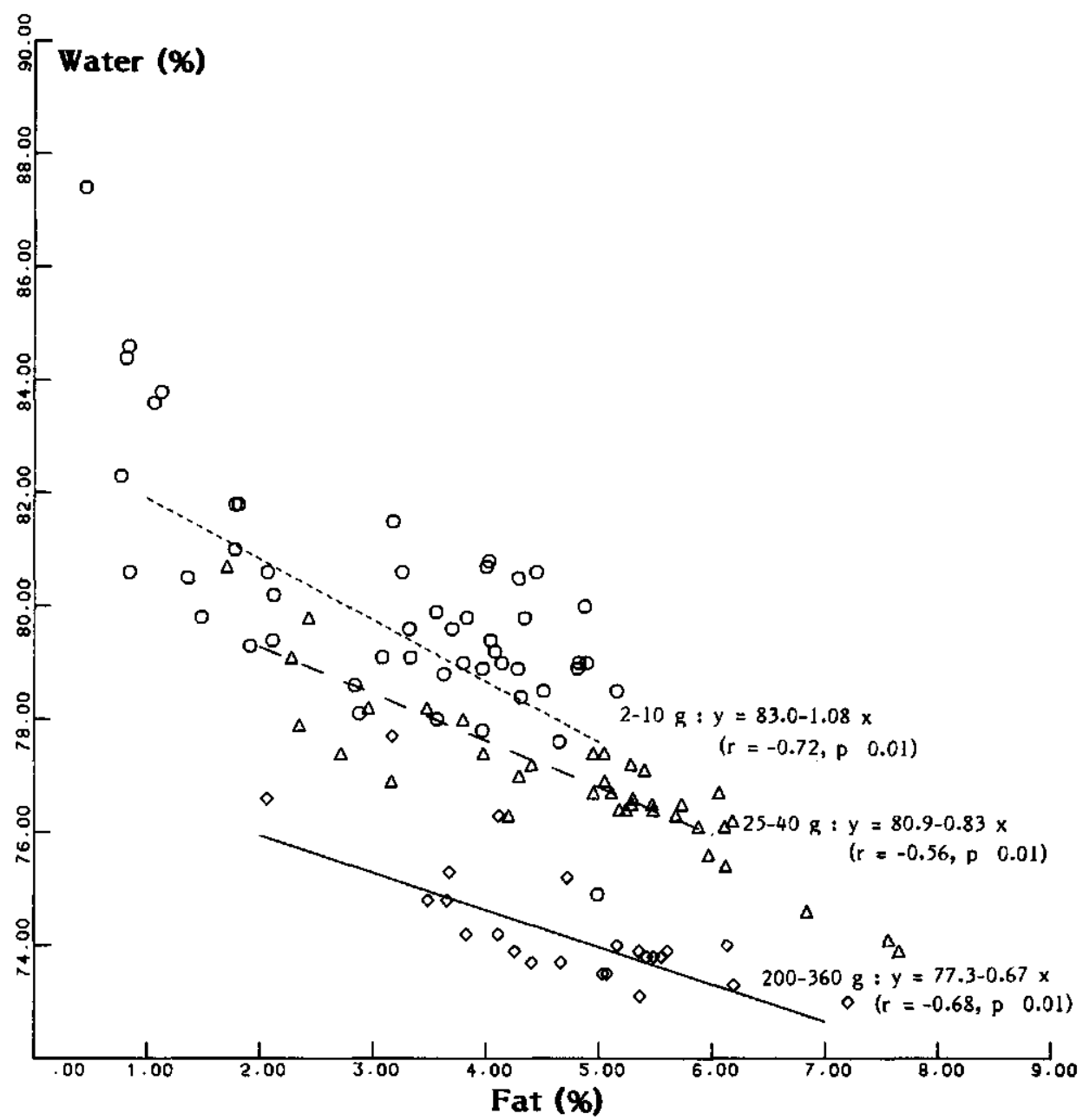

Fig. 5. Water content (\%) in relation to fat content (\%) of three size groups of C. gariepinus.

pendently obtained results were available from balance respiration experiments at 20,25 and $30^{\circ} \mathrm{C}$. Four size groups of $C$. gariepinus were fed at five different levels at each temperature. The experimental results are summarized in Tables 3,4 and 5. The experimental procedures are similar to those of Hogendoorn (1983a). In Hogendoorn's paper experimental results obtained at $25^{\circ} \mathrm{C}$ are also discussed. From these experiments the following initial values and input variables were used:

(1) initial mean body weight (g) of the fish;

(2) initial fat content (\%) of the fish, calculated from energy $\left(\mathrm{kJ}^{\prime} \mathrm{g}^{-1}\right)$ and nitrogen (\%) content;

fat $=2.53 \cdot$ energy $-3.73 \cdot$ nitrogen . 


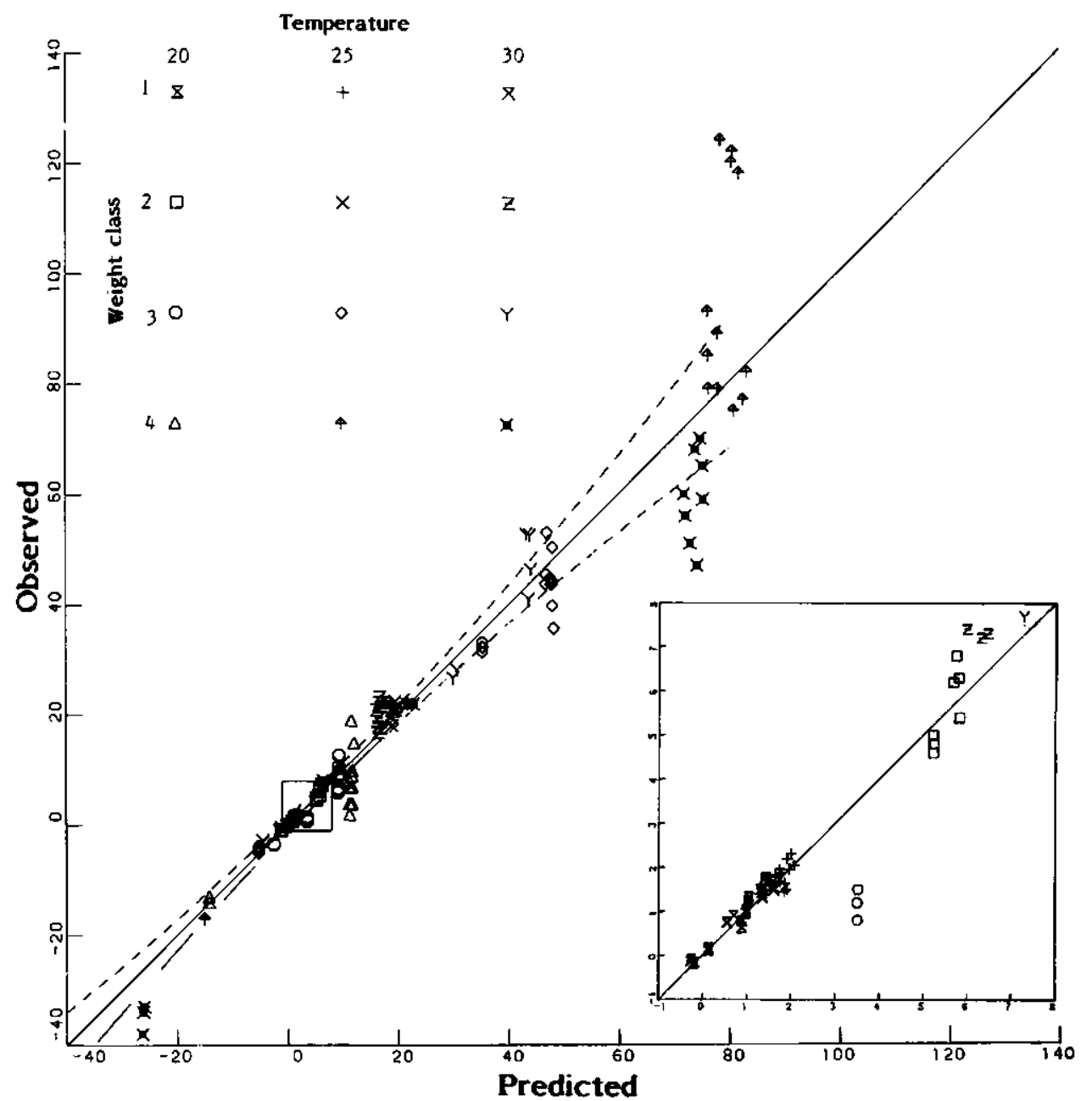

Fig. 6. Predicted weight gain from the simulation model and experimental results of weight gain (g) in aquarium trials. Symbols in the upper left corner of the figure.

Feed composition, feeding level and water temperature values were set equal to those of the experiments.

\section{RESULTS AND DISCUSSION}

The test results are presented in Figs. 9, 10,11 and 12 for growth, protein gain, fat gain and oxygen consumption respectively. The bisectors represent perfect agreement between observed ( $y$ axis) and predicted ( $x$ axis) values. The mean ratios of $y$ to $x$ values are: for growth, 1.04; for protein gain, 1.05; for fat gain, 1.08; and for oxygen consumption, 1.02. The largest differences between 


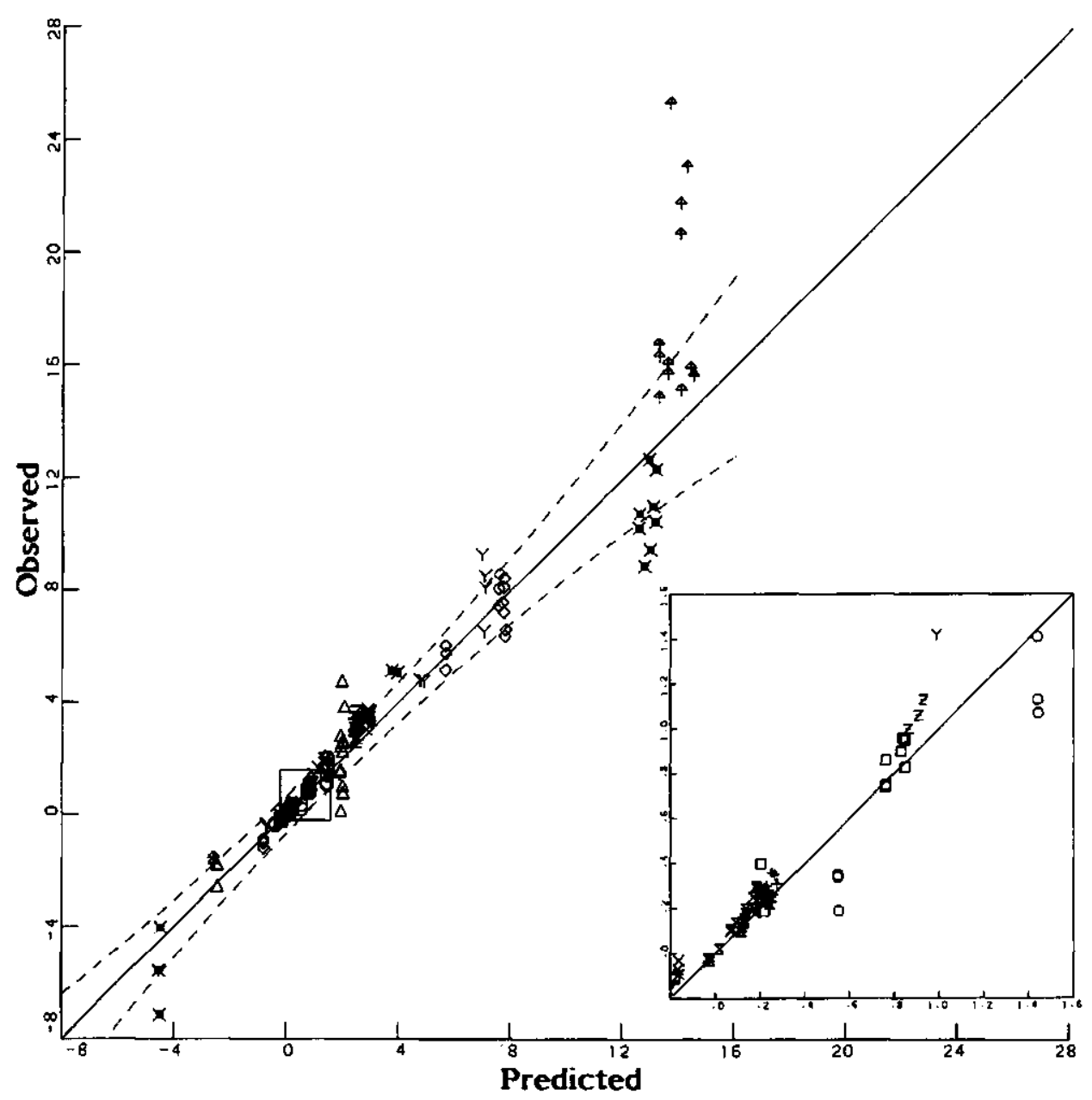

Fig. 7. Predicted output from the simulation model and experimental results of protein gain (g) in aquarium trials. (Symbols as in Fig. 6).

observed and predicted values occur at the higher feeding levels. If the two highest feeding levels are omitted, the mean $y$ to $x$ ratios are 1.02, 1.02, 1.01, and 0.95 for growth, protein gain, fat gain and oxygen consumption, respectively. Apparently the fixed maximum attainable growth per day in the model underestimates the maximum growth realized in the balance respiration experiments. This may be caused by the difference in length of the daily feeding period between the balance respiration experiments and the experiments of which the results were used for calibration. In the latter experiments feeding took place during $12 \mathrm{~h}$ per day. In the balance respiration experiments feed was administered continuously for $24 \mathrm{~h}$ each day. This difference may have affected intake, digestion and absorption of nutrients. 


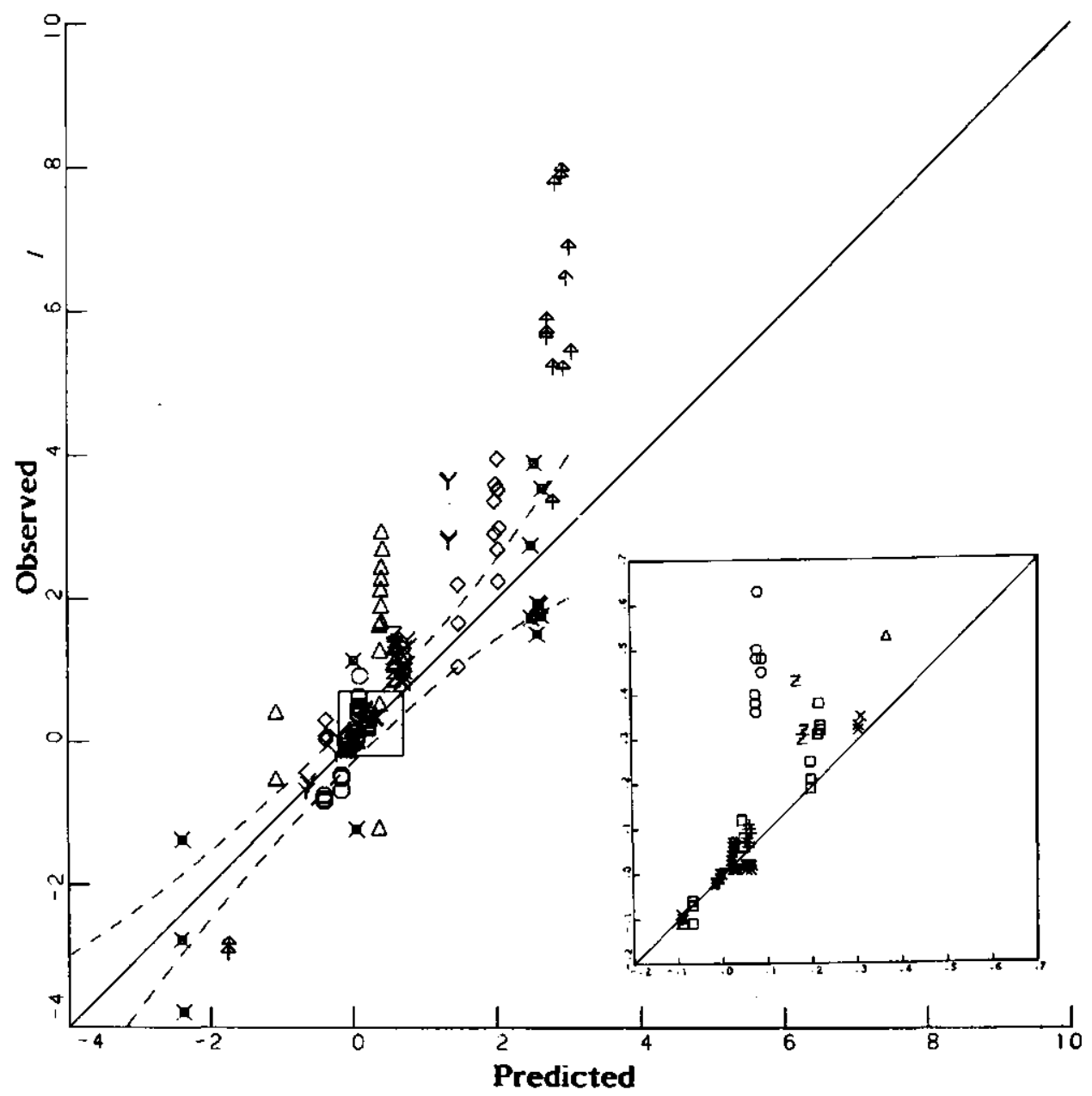

Fig. 8. Predicted output from the simulation model and experimental results of fat gain (g) in aquarium trials. (Symbols as in Fig. 6).

In fish production the higher feeding levels, and thus the higher growth rates, are the most important. It is therefore most valuable to focus research on those mechanisms which control maximum feed intake. This is the more important when simulating growth on diets of different composition, because maximum growth rate attainable in one day may differ for various compositions (Brett, 1979). In the next publication of this series this will be elaborated.

In the test results no systematic deviations due to thermal effects could be found. Apparently thermal effects on routine metabolic rate and maximum attainable growth rate were estimated correctly. Routine metabolic rate increases at higher temperatures, but at the same time fish are able to consume 
TABLE 3

Experimental results: initial and final weight (g), experimental period (day), amount of feed ( $\mathrm{g}$ in experimental period), feed and body composition, and oxygen consumption ( 1 in experimental period) of four size groups of C. gariepinus, fed five different feeding levels at $20^{\circ} \mathrm{C}$

\begin{tabular}{|c|c|c|c|c|c|c|c|c|}
\hline \multirow{2}{*}{$\begin{array}{l}\text { Size } \\
\text { group }\end{array}$} & \multicolumn{2}{|c|}{ Body weight } & \multirow[t]{2}{*}{ Days } & \multirow{2}{*}{$\begin{array}{l}\text { Feed } \\
\text { (g) }\end{array}$} & \multirow{2}{*}{$\begin{array}{l}\text { Dry matter } \\
\text { (\%) }\end{array}$} & \multirow{2}{*}{$\begin{array}{l}\mathrm{N} \\
(\%)\end{array}$} & \multirow{2}{*}{$\begin{array}{l}\text { Energy } \\
\text { (kJ/g) }\end{array}$} & \multirow{2}{*}{$\begin{array}{l}\mathrm{O}_{2} \text { consumption } \\
\text { (l) }\end{array}$} \\
\hline & $\begin{array}{l}\text { start } \\
\text { (g) }\end{array}$ & $\begin{array}{l}\text { end } \\
\text { (g) }\end{array}$ & & & & & & \\
\hline \multirow[t]{7}{*}{1} & \multicolumn{2}{|c|}{ Initial sample } & & & 18.9 & 11.3 & 24.4 & \\
\hline & 1.34 & 0.97 & 28 & 0.00 & 15.3 & 12.0 & 20.4 & 0.10 \\
\hline & 1.77 & 1.62 & 28 & 0.25 & 17.7 & 11.6 & 24.5 & 0.19 \\
\hline & 1.35 & 2.74 & 28 & 1.08 & 20.1 & 11.1 & 23.6 & 0.24 \\
\hline & 1.47 & 4.00 & 28 & 2.62 & 21.0 & 10.8 & 25.0 & 0.38 \\
\hline & 1.37 & 4.00 & 28 & 3.81 & 20.2 & 10.9 & 23.6 & 0.37 \\
\hline & Feed & & & & 90.1 & 8.4 & 22.2 & \\
\hline \multirow[t]{7}{*}{2} & \multicolumn{3}{|c|}{ Initial sample } & & 21.3 & 10.5 & 24.8 & \\
\hline & 5.24 & 4.10 & 28 & 0.00 & 20.4 & 11.3 & 24.0 & 0.34 \\
\hline & 5.97 & 5.75 & 28 & 0.84 & 21.6 & 11.0 & 24.1 & 0.58 \\
\hline & 5.92 & 7.85 & 28 & 3.17 & 22.4 & 10.8 & 24.8 & 0.64 \\
\hline & 5.84 & 7.63 & 28 & 6.98 & 21.8 & 10.6 & 25.1 & 1.86 \\
\hline & 5.26 & 7.11 & 28 & 9.44 & 22.0 & 10.8 & 24.7 & 0.91 \\
\hline & Feed & & & & 89.6 & 8.9 & 22.6 & \\
\hline \multirow[t]{7}{*}{3} & \multicolumn{4}{|c|}{ Initial sample } & 24.1 & 10.2 & 26.1 & \\
\hline & 23.7 & 18.6 & 28 & 0.00 & 24.1 & 10.2 & 26.4 & 1.06 \\
\hline & 23.2 & 20.9 & 28 & 2.60 & 24.8 & 9.9 & 26.3 & 1.54 \\
\hline & 22.8 & 25.7 & 28 & 9.16 & 25.4 & 10.0 & 25.4 & 1.93 \\
\hline & 21.9 & 26.8 & 28 & 18.2 & 25.9 & 9.6 & 25.9 & 2.96 \\
\hline & 22.7 & 28.4 & 28 & 28.3 & 26.1 & 9.7 & 25.9 & 2.89 \\
\hline & Feed & & & & 89.9 & 8.8 & 22.6 & \\
\hline \multirow[t]{7}{*}{4} & \multicolumn{4}{|c|}{ Initial sample } & 24.1 & 10.8 & 23.9 & \\
\hline & 76.9 & 70.2 & 28 & 0.00 & 23.9 & 11.3 & 22.9 & 1.35 \\
\hline & 73.2 & 75.6 & 28 & 6.15 & 24.1 & 11.0 & 23.4 & 2.96 \\
\hline & 74.8 & 88.5 & 28 & 16.8 & 24.3 & 10.8 & 24.3 & 3.18 \\
\hline & 72.2 & 96.0 & 28 & 32.5 & 24.6 & 10.7 & 24.4 & 5.35 \\
\hline & 76.9 & 100 & 28 & 51.9 & 25.2 & 10.5 & 24.0 & 5.75 \\
\hline & Feed & & & & 90.7 & 8.6 & 22.7 & \\
\hline
\end{tabular}

more feed and grow faster. Relations in the biochemical pathways of the intermediate metabolism are principally not affected by temperature.

Two sets of results were systematically overestimated by the model. They belong to the weight classes 2 and 3 at $20^{\circ} \mathrm{C}$. It is thought that the reason for these deviations can be found in the experimental procedures and originates from fish not fully acclimated at the start of the respective two experiments.

The data in Tables 3, 4 and 5 show a similar overall relation between, on the one hand, feed administered and, on the other, growth, protein and fat gain. 


\section{TABLE 4}

Experimental results: initial and final weight (g), experimental period (day), amount of feed ( $\mathrm{g}$ in experimental period), feed and body composition, and oxygen consumption ( $l$ in experimental period) of four size groups of $C$. gariepinus, fed five different feeding levels at $25^{\circ} \mathrm{C}$

\begin{tabular}{|c|c|c|c|c|c|c|c|c|}
\hline \multirow{2}{*}{$\begin{array}{l}\text { Size } \\
\text { group }\end{array}$} & \multicolumn{2}{|c|}{ Body weight } & \multirow[t]{2}{*}{ Days } & \multirow{2}{*}{$\begin{array}{l}\text { Feed } \\
\text { (g) }\end{array}$} & \multirow{2}{*}{$\begin{array}{l}\text { Dry matter } \\
(\%)\end{array}$} & \multirow{2}{*}{$\begin{array}{l}N \\
(\%)\end{array}$} & \multirow{2}{*}{$\begin{array}{l}\text { Energy } \\
(\mathrm{kJ} / \mathrm{g})\end{array}$} & \multirow{2}{*}{$\begin{array}{l}\mathrm{O}_{2} \text { consumption } \\
\text { (l) }\end{array}$} \\
\hline & $\begin{array}{l}\text { start } \\
\text { (g) }\end{array}$ & $\begin{array}{l}\text { end } \\
\text { (g) }\end{array}$ & & & & & & \\
\hline \multirow[t]{7}{*}{1} & \multicolumn{2}{|c|}{ Initial sample } & & & 17.0 & 11.2 & 24.7 & \\
\hline & 1.57 & 1.24 & 21 & 0.00 & 16.6 & 12.2 & 22.3 & 0.09 \\
\hline & 1.54 & 1.59 & 21 & 0.25 & 18.6 & 12.0 & 21.3 & 0.19 \\
\hline & 1.65 & 3.95 & 21 & 1.52 & 19.4 & 11.3 & 23.3 & 0.42 \\
\hline & 1.58 & 6.09 & 21 & 3.50 & 20.8 & 11.1 & 24.3 & 0.71 \\
\hline & 1.50 & 7.23 & 21 & 5.42 & 20.0 & 11.1 & 23.9 & 0.83 \\
\hline & Feed & & & & 92.1 & 9.1 & 23.3 & \\
\hline \multirow[t]{7}{*}{2} & \multicolumn{2}{|c|}{ Initial sample } & & & 21.6 & 10.8 & 22.8 & \\
\hline & 7.99 & 6.85 & 28 & 0.00 & 19.8 & 11.5 & 21.4 & 0.58 \\
\hline & 7.83 & 9.58 & 28 & 1.66 & 20.8 & 11.8 & 22.2 & 1.10 \\
\hline & 7.26 & 19.3 & 28 & 7.57 & 22.2 & 11.4 & 23.6 & 2.11 \\
\hline & 7.17 & 36.5 & 28 & 18.8 & 23.8 & 10.7 & 23.8 & 3.73 \\
\hline & 6.84 & 47.0 & 28 & 29.1 & 24.3 & 10.6 & 24.8 & 4.55 \\
\hline & Feed & & & & 89.1 & 8.9 & 22.4 & \\
\hline \multirow[t]{7}{*}{3} & \multicolumn{3}{|c|}{ Initial sample } & & 23.4 & 10.4 & 24.5 & \\
\hline & 49.2 & 40.9 & 28 & 0.00 & 23.7 & 11.0 & 24.8 & 2.32 \\
\hline & 50.0 & 50.5 & 28 & 7.00 & 24.4 & 10.9 & 24.7 & 4.47 \\
\hline & 42.9 & 73.0 & 28 & 25.6 & 25.6 & 10.3 & 23.8 & 6.92 \\
\hline & 41.2 & 99.0 & 28 & 57.4 & 26.0 & 10.5 & 25.4 & 9.10 \\
\hline & 40.2 & 101 & 28 & 85.0 & 26.0 & 10.4 & 24.8 & 11.8 \\
\hline & Feed & & & & 90.8 & 8.3 & 22.5 & \\
\hline \multirow[t]{7}{*}{4} & \multicolumn{3}{|c|}{ Initial sample } & & 24.8 & 10.6 & 25.0 & \\
\hline & 94.0 & 79.2 & 42 & 0.00 & 24.4 & 11.0 & 24.3 & 5.66 \\
\hline & 96.9 & 108 & 42 & 20.3 & 24.8 & 10.8 & 24.0 & 11.6 \\
\hline & 94.7 & 150 & 42 & 52.8 & 26.5 & 10.3 & 25.3 & 15.3 \\
\hline & 82.9 & 203 & 42 & 107 & 27.0 & 10.3 & 25.9 & 22.7 \\
\hline & 92.7 & 222 & 42 & 198 & 27.6 & 10.0 & 25.6 & 29.5 \\
\hline & Feed & & & & 90.8 & 8.3 & 22.5 & \\
\hline
\end{tabular}

Under fasting conditions growth, protein and fat gain were negative. The loss of fat was relatively greater than protein loss, resulting in a reduction of the fat percentage of the fish. With 'maintenance' feeding (the second feeding level) growth and protein gain were positive, while fat gain was still negative. At the third feeding level feed conversion was the best in most cases. At the fourth and/or fifth feeding level growth, protein and fat gain levelled off to a maximum in most cases.

In the model all the available feed nutrients are used for biosynthesis. The 


\section{TABLE 5}

Experimental results: initial and final weight (g), experimental period (day), amount of feed ( $\mathrm{g}$ in experimental period), feed and body composition, and oxygen consumption ( 1 in experimental period) of four size groups of $C$. gariepinus, fed five different feeding levels at $30^{\circ} \mathrm{C}$

\begin{tabular}{llllllll}
\hline $\begin{array}{l}\text { Size } \\
\text { group }\end{array}$ & $\begin{array}{l}\text { Body weight } \\
\text { start end }\end{array}$ & Days & $\begin{array}{l}\text { Feed } \\
(\mathrm{g})\end{array}$ & $\begin{array}{l}\text { Dry matter } \\
(\%)\end{array}$ & $\begin{array}{l}\mathrm{N} \\
(\%)\end{array}$ & $\begin{array}{l}\text { Energy } \\
(\mathrm{kJ} / \mathrm{g})\end{array}$ & $\begin{array}{l}\mathrm{O}_{2} \text { consumption } \\
(\mathrm{l})\end{array}$
\end{tabular}

(in D.M.)

\begin{tabular}{|c|c|c|c|c|c|c|c|c|}
\hline \multirow[t]{7}{*}{1} & \multicolumn{4}{|c|}{ Initial sample } & 19.8 & 11.8 & 24.8 & \\
\hline & 3.06 & 2.02 & 28 & 0.00 & 12.6 & 11.8 & 18.9 & 0.39 \\
\hline & 2.96 & 2.44 & 28 & 0.42 & 15.4 & 11.6 & 19.3 & 0.55 \\
\hline & 2.82 & 8.27 & 28 & 3.50 & 18.1 & 12.3 & 20.4 & 1.14 \\
\hline & 3.00 & 23.2 & 28 & 12.5 & 20.8 & 11.7 & 21.8 & 3.09 \\
\hline & 3.00 & 38.9 & 28 & 25.7 & 21.1 & 11.5 & 24.8 & 4.12 \\
\hline & Feed & & & & 91.0 & 8.7 & 21.9 & \\
\hline \multirow[t]{7}{*}{2} & \multicolumn{4}{|c|}{ Initial sample } & 22.3 & 11.4 & 22.3 & \\
\hline & 31.2 & 27.0 & 28 & 0.00 & 19.3 & 12.1 & 22.2 & 2.18 \\
\hline & 31.7 & 34.0 & 28 & 4.43 & 20.2 & 12.1 & 22.6 & 3.94 \\
\hline & 31.8 & 66.7 & 28 & 25.3 & 22.1 & 11.3 & 23.1 & 7.69 \\
\hline & 38.0 & 101 & 28 & 61.5 & 23.5 & 11.2 & 23.3 & 11.5 \\
\hline & 31.4 & 109 & 28 & 110 & 24.6 & 10.9 & 25.4 & 14.8 \\
\hline & Feed & & & & 92.4 & 8.9 & 22.6 & \\
\hline \multirow[t]{7}{*}{3} & \multicolumn{4}{|c|}{ Initial sample } & 24.3 & 11.1 & 23.2 & \\
\hline & 112 & 94.5 & 28 & 0.00 & 21.2 & 11.7 & 22.8 & 8.14 \\
\hline & 111 & 113 & 28 & 15.5 & 22.4 & 11.4 & 21.3 & 13.0 \\
\hline & 108 & 171 & 28 & 56.1 & 22.3 & 11.6 & 22.8 & 19.3 \\
\hline & 113 & 199 & 28 & 117 & 23.7 & 10.9 & 23.1 & 23.3 \\
\hline & 117 & 238 & 28 & 182 & 23.9 & 11.0 & 23.5 & 25.7 \\
\hline & Feed & & & & 93.2 & 9.0 & 22.3 & \\
\hline \multirow[t]{7}{*}{4} & \multicolumn{4}{|c|}{ Initial sample } & 25.1 & 11.2 & 23.0 & \\
\hline & 238 & 205 & 28 & 0.00 & 23.4 & 11.8 & 20.9 & 15.0 \\
\hline & 227 & 233 & 28 & 31.9 & 26.1 & 11.0 & 22.8 & 24.1 \\
\hline & 239 & 330 & 28 & 76.7 & 26.3 & 10.8 & 23.0 & 25.5 \\
\hline & 236 & 360 & 28 & 163 & 28.5 & 10.5 & 23.9 & 35.9 \\
\hline & 234 & 291 & 28 & 260 & 25.9 & 11.1 & 22.6 & 29.1 \\
\hline & Feed & & & & 92.7 & 8.1 & 22.8 & \\
\hline
\end{tabular}

ATP requirements for respiration are met by breaking down body material. If dietary amino acids and glucose were broken down directly, the ATP yield would have been $30 \%$ higher and growth about $5 \%$ better. On the other hand, no correction was made for possible de novo synthesis of amino and fatty acids, which occurs when dietary and body protein and fat composition are not identical. If such a correction had been made, growth would have been slightly less. Because of the satisfactory outcome of the simulation, it is concluded that 


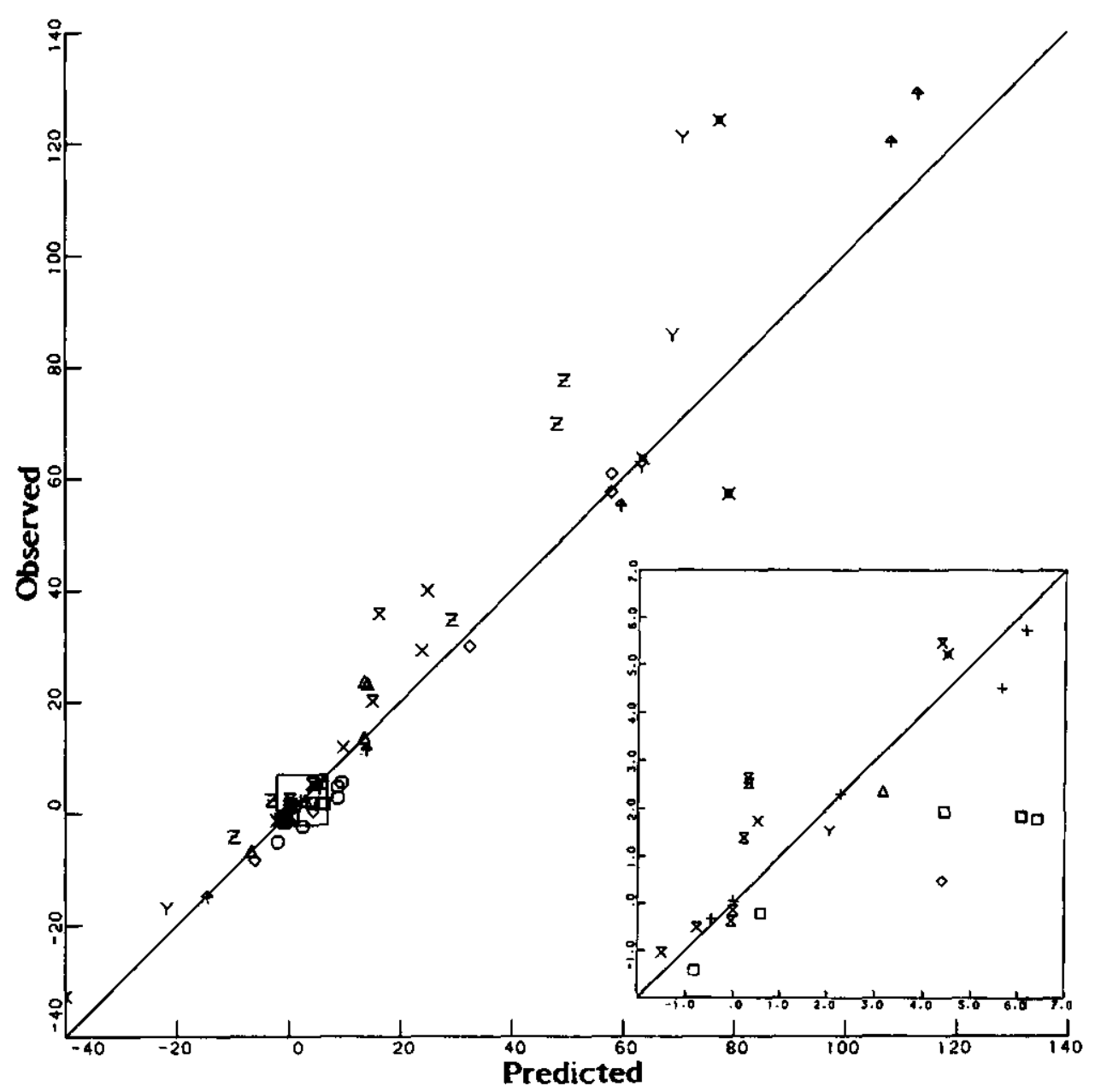

Fig. 9. Predicted output from the simulation model and experimental results of growth (g) in respiration balance trials. (Symbols as in Fig. 6).

probably neither de novo synthesis nor direct breakdown occurs, or that the two have opposite effects of the same magnitude and cancel each other out.

\section{CONCLUSIONS}

It may be concluded that the dynamic simulation model developed estimates effects of feeding level at different temperatures satisfactorily. Research is needed to determine the maximum growth rate of the African catfish, especially when using different feed compositions.

It is believed that the model per se is sufficiently general to be applicable to other species. The model is based on biochemistry. Because biochemistry is 


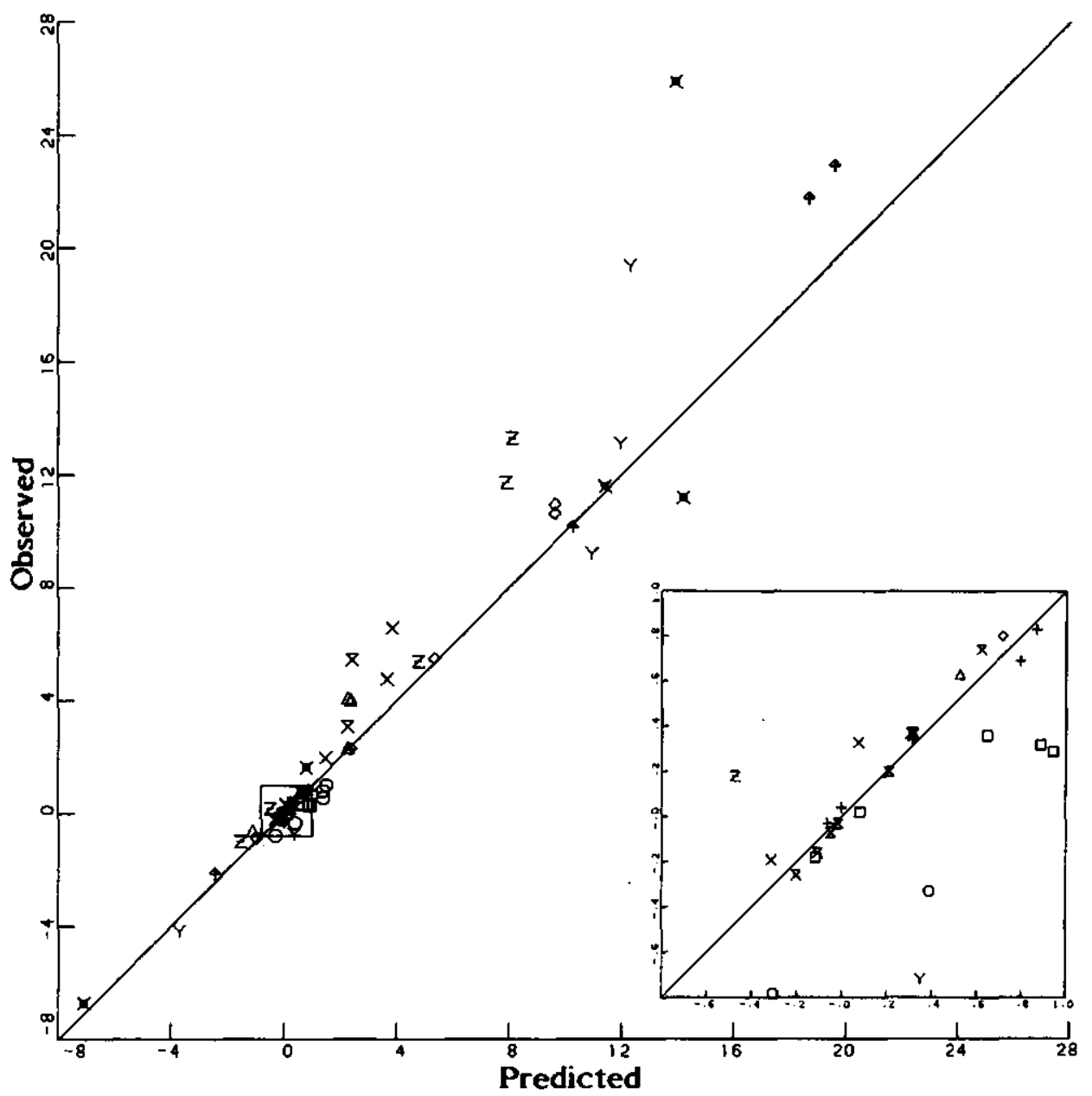

Fig. 10. Predicted output from the simulation model and experimental results of protein gain (g) in respiration balance trials. (Symbols as in Fig. 6).

generally applicable to all organisms, the model is general. The parameter values which were calibrated, and the assumptions made, should be checked with data from research on the species of interest. The biochemical reaction equations are easily and accurately transformed into weight yields. They also give information on gaseous exchange, while the traditional energy equations give no such data (Penning de Vries et al., 1974).

The flexibility of the model permits it to be altered in a number of ways. Principally, the model is sufficiently general for other applications, for instance to estimate effects of diet composition, if the proper parameter values for the regulation of biomass composition and maximum growth attainable in one day are available. It differs from related bioenergetic models which require that 


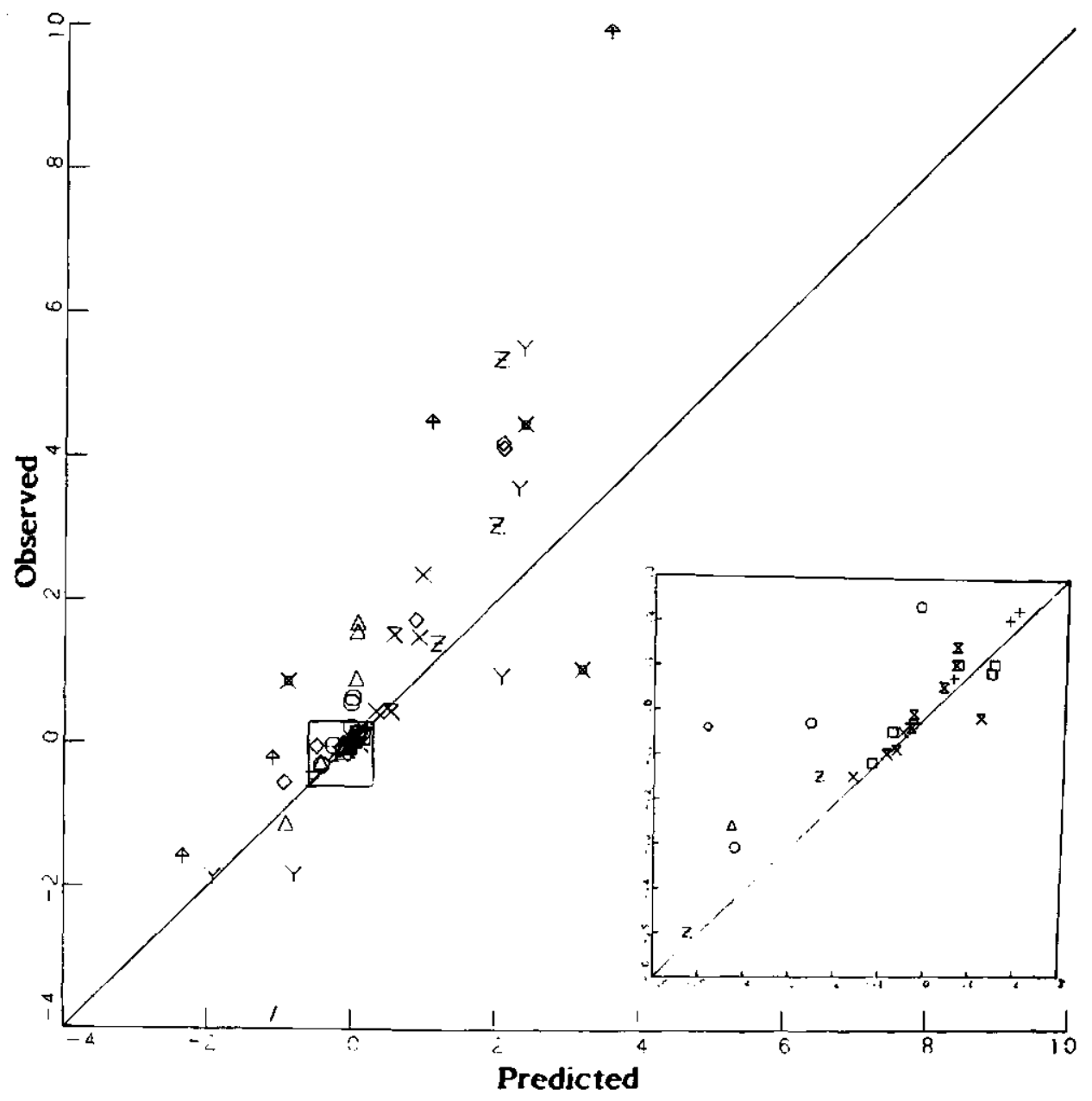

Fig. 11. Predicted output from the simulation model and experimental results of fat gain $(\mathrm{g})$ in respiration balance trials. (Symbols as in Fig. 6).

differences in food must be minor in respect to chemical composition and energetic value.

The test results indicate that the fish utilize nutrients and body material at maximum biochemical efficiency. Thus, selection on higher efficiency of biosynthesis to improve production is useless. Higher production levels through genetic selection are possible (Weatherley, 1976). Assimilation rates could be augmented through improving digestive capability. Selection on activity (lethargic fishes) will result in lower maintenance requirements and better growth. 


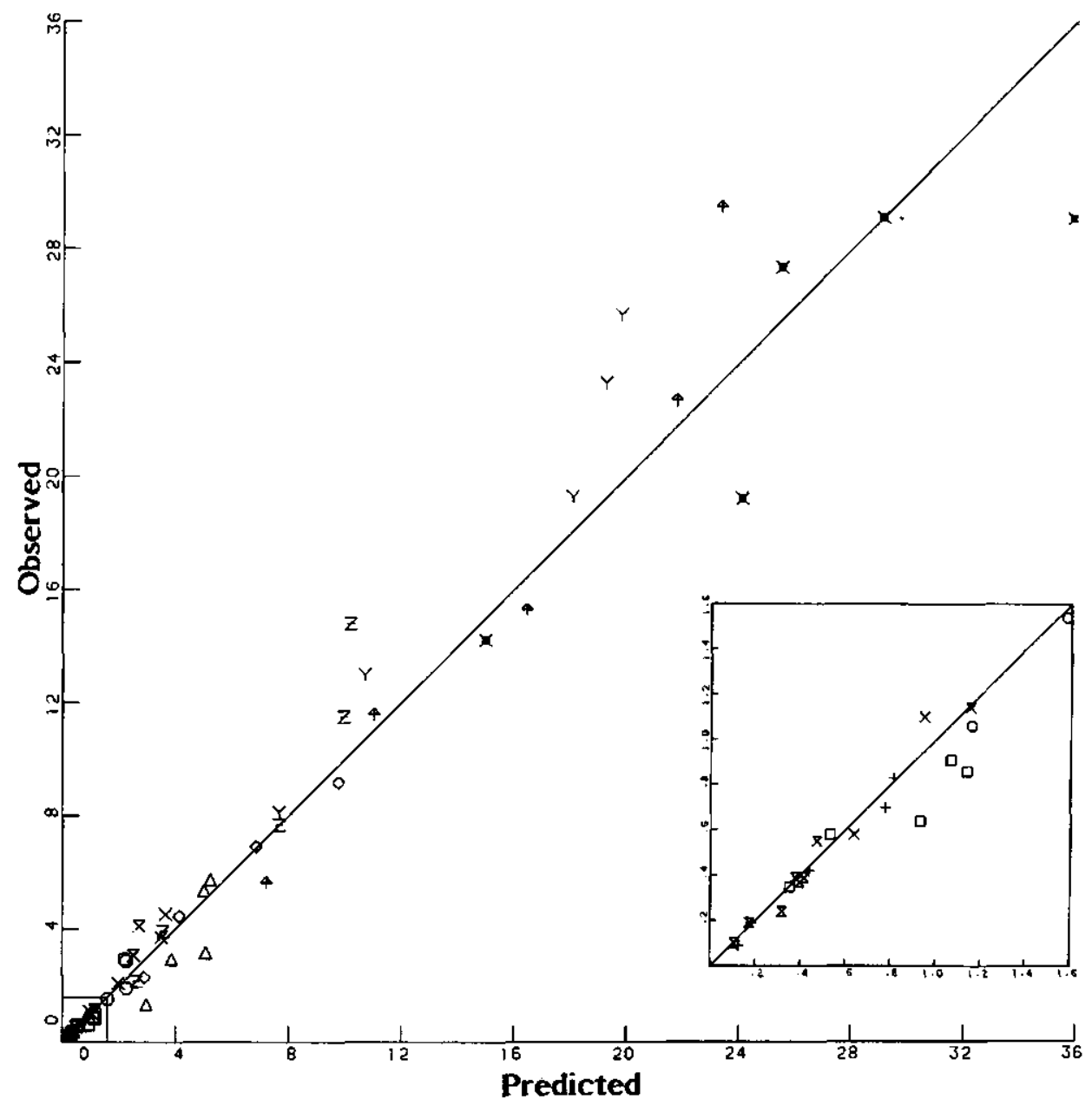

Fig. 12. Predicted output from the simulation model and experimental results of oxygen consumption (1) in respiration balance trials. (Symbols as in Fig. 6).

\section{REFERENCES}

Beamish, F.W.H., 1974. Ration size and digestion in largemouth bass, Micropterus salmoides Lacepede. Can. J. Zool., 50: 153-164.

Beverton, R.J.H. and Holt, S.J., 1957. On the dynamics of exploited fish populations. Fish Invest. Lond. Ser. II, 19: 533 pp.

Brett, J.R., 1979. Environmental factors and growth. In: W.S. Hoar, D.J. Randall and J.R. Brett (Editors), Fish Physiology, Vol. VIII: Bioenergetics and Growth. Academic Press, New York, pp. 599-677.

Dagley, S. and Nicholson, D.E., 1970. An Introduction to Metabolic Pathways. Blackwell Scientific Publications, Oxford, 343 pp.

De Wit , C.T., 1982. Simulation of living systems. In: F.W.T. Penning de Vries and H.H. van Laar 
(Editors), Simulation of Plant Growth and Crop Production . (Simulation Monographs) Pudoc, Wageningen, pp. 3-8.

Elliot, J.M. and Davison, W., 1975. Energy equivalents of oxygen consumption in animal energetics. Oecologia, 19: 195-201.

Forrester, J.P., 1961. Industrial Dynamics. Massachusetts Institute of Technology Press, Cambridge, MA, $464 \mathrm{pp}$.

Forster, R.P. and Goldstein, L., 1969. Formation of excretory products. In: W.S. Hoar, D.J. Randall and J.R. Brett (Editors), Fish Physiology Vol. I: Excretion, lonic Regulation and Metabolism. Academic Press, New York, pp. 313-350.

From, J. and Rasmussen, G., 1984. A growth model, gastric evacuation, and body composition in rainbow trout, Salmo gairdneri, Richardson, 1836. Dana, 3: 61-139.

Hogendoorn, H., 1983a. Growth and production of the African catfish, Clarias lazera (C \& V.). III. Bioenergetic relations of body weight and feeding level. Aquaculture, 35: 1-17.

Hogendoorn, H., 1983b. The African catfish (Clarias lazera C. \& V., 1840)-a new species for Aquaculture. Dissertation, Agricultural University, Wageningen, The Netherlands, 135 pp.

Hogendoorn, H., Jansșen, J.A.J., Koops, W.J., Machiels, M.A.M., Van Ewijk, P.H. and Van Hees, J.P., 1983. Growth and production of the African catfish, Clarias lazera (C. \& V.). II. Effects of body weight, temperature and feeding level in intensive tank culture. Aquaculture, 34: 265-285.

IBM, 1975. Continuous System Modelling Program III (CSMP III), Program Reference Manual. IBM SH 19-7001-3. Tech. Publ. Dept., White Plains, NY, 206 pp.

Love, R.M., 1970. The Chemical Biology of Fishes. Academic Press, New York, 547 pp.

Love, R.M., 1980. The Chemical Biology of Fishes. Vol. 2: Advances 1968-1977. Academic Press, New York, $943 \mathrm{pp}$.

Peter, B.E., 1979. The brain and feeding behavior. In: W.S. Hoar, D.J. Randall and J.R. Brett (Editors), Fish Physiology, Vol. VIII: Bioenergetics and Growth. Academic Press, New York, pp. 121-161.

Penning de Vries, F.W.T., Brunsting, A.H.M. and Van Laar, H.H., 1974. Products, requirements and efficiency of biosynthesis: a quantitative approach. J. Theoret. Biol., 45: 339-377.

Ricker, W.E., 1979. Growth rates and models. In: W.S. Hoar, D.J. Randall and J.R. Brett (Editors), Fish Physiology, Vol. VIII: Bioenergetics and Growth. Academic Press, New York, pp. 678-744.

Schalles, J.F. and Wissing, T.E., 1976. Effects of dry pellet diets on the metabolic rates of bluegill, Lipomis macrochirus. J. Fish. Res. Board Can., 33: 2443-2449.

Schulz, A.R., 1978. Simulation of energy metabolism in the simple stomached animal. Br. J. Nutr., 39: 235-254.

Stryer, L., 1975. Biochemistry. W.H. Freeman, San Francisco, CA, 877 pp.

Teugels, G.G., 1984. The nomenclature of African Clarias species used in aquaculture. Aquaculture, 38: 373-374.

Von Bertalanffy, L., 1957. Quantitative laws in metabolism and growth. Q. Rev. Biol., 32(3): 217-231.

Weatherley, A.H., 1976. Factors affecting maximization of fish growth. J. Fish. Res. Board Can., 33: 1046-1058.

Winberg, G.G., 1956. Rate of metabolism and food requirements of fishes. Belorusskovo Gosudastvenno Universiteta imeni V.I. Lenina Minsk, 253 pp. (Fish. Res. Board Can., Transl. Ser. no. 194). 


\title{
A Dynamic Simulation Model for Growth of the African Catfish, Clarias gariepinus (Burchell 1822) \\ II. Effect of Feed Composition on Growth and Energy Metabolism ${ }^{1}$
}

\author{
M.A.M. MACHIELS and A.M. HENKEN \\ Department of Fish Culture and Fisheries, Agricultural University, P.O. Box 338, Wageningen \\ (The Netherlands)
}

(Accepted 11 November 1986)

\begin{abstract}
Machiels, M.A.M. and Henken, A.M., 1987. A dynamic simulation model for growt th of the African catfish, Clarias gariepinus (Burchell 1822). II. Effect of feed composition on growth and energy metabolism. Aquaculture, 60: 33-53.
\end{abstract}

A dynamic simulation model was adapted to investigate the effect of feed composition on growth of Clarias gariepinus. The effect of feed composition was restricted to that of the macronutrients, i.e. protein, fat and carbohydrates. Most parameters used in the model were derived from the literature. Parameters which were expected to have specific values for the species used, or which could not be derived from the literature, were calibrated with experimental results. Results used for calibration originate from an 84-day feeding trial with 20 different semi-moist diets. The protein content of these varied from 20 to $60 \%$ and the fat content from 0 to $38 \%$.

Data used to test the model originated from balance respiration experiments. In these experiments dietary protein content varied from 20 to $40 \%$ and fat content from 4 to $29 \%$. A dry pelleted feed was used in these experiments. The test results of the model for fresh weight gain, protein gain, fat gain and oxygen consumption were compared with the independently obtained results of the balance respiration experiments.

It is concluded that the model predicts reasonably well the effects of feed composition on growth and growth composition. The predicted values are in agreement with the observed values, except for the diets with the highest fat content. With these diets the predictions are overestimated. During the modelling procedure it became apparent that feed intake is influenced by the fat content of the fish biomass. Fat fish consume less than leaner fish of the same weight.

\section{INTRODUCTION}

Nutrient requirements are mostly determined by performing dose-response experiments (Zeitoun et al., 1976). However, it would require many experi-

\footnotetext{
'Paper presented at the IFAC Symposium on Automation and Data Processing in Aquaculture. August 1986, Trondheim, Norway.
} 
ments, much effort and a lot of time and money to evaluate in this way the requirements of all species cultured. The same is true even for a single species, considering the variation in culture conditions used.

Nutrient requirements already determined relate to fish of proven importance, like salmon, trout, carp and channel catfish. Knowledge of nutrient requirements of species which have become of interest recently, like the African catfish, Clarias gariepinus (Burchell 1822) is restricted. The African catfish is regarded as a promising candidate for aquaculture (Hogendoorn, 1983). Some experiments have been performed to elucidate the protein and energy requirements of this fish (Machiels and Henken, 1985; Henken et al., 1986). Recommendations on feed composition for this fish are based on those experiments.

Recommendations based on experimental results, however, can always be questioned, because culture conditions in practice are rarely identical to those in experiments. Therefore the relation between feed composition and production results should be known over a broad range of culture conditions. Instead of doing numerous experiments to elucidate the relation between feed composition and growth, modelling may be an alternative.

The objective of the present study is to develop an explanatory model for growth of the African catfish. In the first paper of this series a model was presented which is suitable for estimating effects of feeding level on growth (Machiels and Henken, 1986). In this paper the model will be adapted to estimate effects of feed composition on growth. The effect of feed composition studied is restricted to the effect of the macronutrients, i.e. protein, fat and carbohydrates.

\section{MODEL ADAPTATION AND PARAMETERIZATION}

\section{The model}

The starting point in the model is the amount and the composition of the feed provided. When the digestibilities of the nutrients are known, the amounts of amino acids, fatty acids and glucose absorbed can be calculated.

The amounts of protein and fat synthesized from these absorbed nutrients are determined by biochemical reaction equations which describe the conversions in the intermediate metabolism. Energy requirements for respiration are met by oxidizing body material. The amount respired is determined by routine metabolism, feeding metabolism and the energy requirements for biosynthesis. Protein and fat gains are calculated as the difference between biosynthesis and breakdown for respiration. Fresh body weight gain is related to the protein gain. Fat gain affects only the body composition. All the processes are calculated on a 1-day basis. The resulting change in biomass is fixed. For new circumstances the calculations are repeated. 


\section{Feed intake}

Feed consumption by the fish is determined by the daily feed allowance. At low feeding levels the amount of feed consumed will be similar to the amount provided. At higher feeding levels there may be a difference between these two amounts.

In the first paper of this series (Machiels and Henken, 1986), feed intake was determined by maximum attainable growth. This may indeed be applicable when a fixed dietary composition is used. Because the maximum attainable growth is highly dependent on the feed composition (Brett, 1979), while the amount of feed at which maximum growth is reached is less variable, we chose to determine the maximum feed intake by the fresh body weight and the temperature (Hogendoorn et al., 1983).

\section{Protein, fat and carbohydrates: function and metabolism}

Part of the nutrients consumed will be digested in the fish. Protein, fat and carbohydrates are broken down to amino acids, glycerol + fatty acids and monosaccharides, respectively. After digestion, absorption can take place. The amount of nutrients absorbed can be calculated when the amount consumed and the respective digestibilities are known.

Amino acids can be divided in non-essential and essential amino acids. The first can be made by the fish itself from glucose and nitrogen. The others must be given with the feed. Protein synthesis will occur only when all essential amino acids are present. Amino acids known to be essential for most species studied are: arginine, histidine, leucine, isoleucine, lysine, methionine, phenylalanine, threonine, tryptophan and valine (Millikin, 1982). These ten amino acids are expected to be essential for $C$. gariepinus.

Amino acids not used for protein synthesis are converted into glucose and fat. The same occurs when fat synthesis from dietary fat or glucose is insufficient to attain an acceptable body composition. The molecular reaction equations for gluconeogenesis of amino acids are shown in Table 1 together with those for biosynthesis of the non-essential amino acids from glucose and $\mathrm{NH}_{3}$. When the amino acid patterns of absorbed and body protein are known, the amount of protein synthesis from dietary protein can be calculated.

Fatty acids have different functions in the body, one of them being to furnish energy for respiration. In the model, fatty acids absorbed are used for fat synthesis. If the fatty acid compositions of feed and fish are identical, fat synthesis occurs directly from fatty acids and glycerol. If not, then at least part of the fat synthesis takes place via acetyl-CoA. Requirements for energy are met by breaking down body material, mainly fat. When the fat to protein ratio of the fish biomass decreases, an increasing amount of protein is oxidized.

Monosaccharides absorbed are converted in the liver to fat and glycogen. At 
TABLE 1

Individual amino acid (AA) parameter values for the molecular reaction equations

\begin{tabular}{|c|c|c|c|c|c|c|c|c|c|c|c|c|}
\hline \multirow[t]{3}{*}{ No. } & \multirow[t]{3}{*}{ Name } & \multirow{3}{*}{$\begin{array}{l}\text { Mol. } \\
\text { weight } \\
\text { (g) }\end{array}$} & \multicolumn{5}{|c|}{ Gluconeogenesis } & \multicolumn{5}{|c|}{ Biosynthesis } \\
\hline & & & $\mathrm{O}_{2}$ & $\mathrm{CO}_{2}$ & $\mathrm{NH}_{3}$ & GLU & ATP & GLU & $\mathrm{O}_{2}$ & $\mathrm{NH}_{3}$ & $\mathrm{CO}_{2}$ & ATP \\
\hline & & & (a) & (b) & (c) & (d) & (e) & (f) & (g) & (h) & (i) & (j) \\
\hline 1 & ALA & 89 & 0.8 & 0.8 & 1 & 0.4 & 2.5 & 0.5 & 0.5 & 1 & 0.0 & -1.0 \\
\hline 2 & ARG & 174 & 2.5 & 3.0 & 4 & 0.5 & 18.0 & 0.0 & 0.0 & 0 & 0.0 & 0.0 \\
\hline 3 & ASP & 133 & 0.7 & 1.7 & 1 & 0.4 & 2.5 & 0.5 & 0.0 & 1 & -1.0 & -2.0 \\
\hline 4 & ASN & 132 & 0.7 & 1.7 & 2 & 0.4 & 2.5 & 0.5 & 0.0 & 2 & -1.0 & -3.0 \\
\hline 5 & CYS & 121 & 2.2 & 1.2 & 1 & 0.3 & 2.5 & $0.0^{\mathrm{a}}$ & 2.5 & 0 & 2.0 & 2.0 \\
\hline 6 & GLU & 147 & 1.5 & 2.0 & 1 & 0.5 & 7.0 & 1.0 & 1.5 & 1 & 1.0 & 7.0 \\
\hline 7 & GLN & 146 & 1.5 & 2.0 & 2 & 0.5 & 7.0 & 1.0 & 1.5 & 1 & 1.0 & 6.0 \\
\hline 8 & GLY & 75 & 0.6 & 1.1 & 1 & 0.2 & 2.5 & 0.5 & 1.5 & 1 & 1.0 & 6.0 \\
\hline 9 & HIS & 155 & 2.0 & 3.0 & 3 & 0.5 & 10.0 & 0.0 & 0.0 & 0 & 0.0 & 0.0 \\
\hline 10 & ILE & 131 & 4.5 & 3.0 & 1 & 0.5 & 23.0 & 0.0 & 0.0 & 0 & 0.0 & 0.0 \\
\hline 11 & LEU & 131 & 7.5 & 6.0 & 1 & 0.0 & 42.0 & 0.0 & 0.0 & 0 & 0.0 & 0.0 \\
\hline 12 & LYS & 146 & 7.0 & 5.5 & 1 & 0.0 & 37.0 & 0.0 & 0.0 & 0 & 0.0 & 0.0 \\
\hline 13 & MET & 149 & .3 .5 & 2.0 & 1 & 0.5 & 3.0 & 0.0 & 0.0 & 0 & 0.0 & 0.0 \\
\hline 14 & PHE & 165 & 7.0 & 6.0 & 1 & 0.5 & 21.5 & 0.0 & 0.0 & 0 & 0.0 & 0.0 \\
\hline 15 & PRO & 115 & 2.5 & 2.0 & 1 & 0.5 & 12.0 & 1.0 & 0.5 & 1 & 1.0 & 1.0 \\
\hline 16 & HPR & 131 & 1.7 & 1.7 & 1 & 0.5 & 5.7 & 1.5 & 4.0 & 1 & 4.0 & 16.0 \\
\hline 17 & SER & 105 & 0.7 & 1.2 & 1 & 0.3 & 2.5 & 0.5 & 0.0 & 1 & 0.0 & 2.0 \\
\hline 18 & THR & 119 & 1.0 & 1.0 & 1 & 0.5 & 3.0 & 0.0 & 0.0 & 0 & 0.0 & 0.0 \\
\hline 19 & TRP & 204 & 8.5 & 8.0 & 2 & 0.5 & 26.0 & 0.0 & 0.0 & 0 & 0.0 & 0.0 \\
\hline 20 & TYR & 181 & 6.5 & 6.0 & 1 & 0.5 & 24.0 & $0.5^{b}$ & 1.0 & 0 & 3.0 & 15.0 \\
\hline 21 & VAL & 117 & 3.0 & 2.0 & 1 & 0.5 & 14.0 & 0.0 & 0.0 & 0 & 0.0 & 0.0 \\
\hline
\end{tabular}

+ 1 MET; ${ }^{\mathrm{b}}+1$ PHE.

Gluconeogenesis:

$\mathrm{AA}+$ (a) $\mathrm{O}_{2} \rightarrow$ (b) $\mathrm{CO}_{2}+$ (c) $\mathrm{NH}_{3}+$ (d) $\mathrm{GLU}+$ (e) ATP

Biosynthesis:

(f) $\mathrm{GLU}+\left(\right.$ g) $\mathrm{O}_{2}+$ (h) $\mathrm{NH}_{3} \rightarrow$ (i) $\mathrm{CO}_{2}+$ (j) ATP $+\mathrm{AA}$

high dietary carbohydrate levels growth may be decreased. The extent to which this occurs depends on the type of fish, i.e. whether it is carnivorous, omnivorous or herbivorous (Millikin, 1982). C. gariepinus is reported to be omnivorous (Babiker, 1984).

Biosynthesis, respiration and growth

Protein and fat deposited originate from biosynthesis. The ratio of protein to fat synthesis is dependent on feed composition. Part of the body protein and fat is broken down to meet the energy requirements of the fish. Three energy demanding processes are distinguished: (1) routine metabolism; (2) feeding metabolism; (3) biosynthesis. 
The term routine metabolism refers to the metabolic rate of fish under fasting conditions while not restricted in spontaneous activity. Feeding metabolism refers to the increase in metabolic rate above fasting conditions due to feed intake and assimilation.

Above routine and feeding metabolic rate, an increase will occur due to biosynthesis per se. Energy amounts needed for feeding metabolism and biosynthesis, however, are difficult to measure separately. Together they are called the heat increment of the diet. In the previous paper (Machiels and Henken, 1986) the heat increment was related to gross energy consumed. The basis chosen does not matter when the feed composition is fixed, because the ratios between the different nutrients remain the same irrespective of feeding level. However, when the feed composition is variable, the heat increment of every nutrient separately should be known. Measurements of heat increment at different feed compositions were made by Cho et al. (1976). The heat increment proved to be remarkably independent of feed composition, when expressed per unit of nitrogen consumed. In a review paper Cho et al. (1982) reported a value of about $28 \mathrm{~kJ}$ per gram nitrogen consumed based on earlier data (Cho et al., 1976). This is similar to 0.056 mole ATP per gram protein consumed. It is consluded that this value is too low, because even for the synthesis of one gram of protein, 0.06 mole ATP is required.

Jobling (1983) related heat increment to protein synthesis. Protein synthesis is determined to a great extent by protein, or rather digestible protein, intake. In the model the value which is used for feeding metabolic rate was recalculated from the gross energy basis at fixed feed composition (Machiels and Henken, 1986) and expressed per gram of protein consumed.

Net protein and fat gain is calculated as the difference between the amount of protein and fat synthesized and the amount oxidized to meet the energy requirements. Fat gain is thought to affect only the body composition (Machiels and Henken, 1986). Fresh body weight gain is calculated from the protein gain.

\section{Parameterization}

\section{Data used for parameterization}

Most parameters used in the model were derived from the literature. Only parameters which were expected to have specific values for the species used, or which could not be derived from the literature, were calibrated with experimental results.

Data used for calibration were available from an 84-day feeding trial with 20 different semi-moist diets (Henken et al., 1986). The experimental diets were fed to fish held at 24 and $29^{\circ} \mathrm{C}$. Feeding was based on the dry matter content of the diets and the fresh body weight of the fish. The feeding level was about 1.5 and $2.0 \%$ per day at 24 and $29^{\circ} \mathrm{C}$, respectively.

Protein content of the diets varied from 20 to $60 \%$, fat content from 0 to 


\section{TABLE 2}

The casein and fat contents $(\%)$ of the diets in the experiments used for parameterization. The letters are the symbols used in Figs. 3-5 for the various diets

\begin{tabular}{llllll}
\hline & \multicolumn{1}{c}{ Casein } & & & & \\
\cline { 2 - 6 } & \multicolumn{1}{c}{20} & 30 & 40 & 50 & 60 \\
\hline Fat & $9.0(\mathrm{a})$ & $4.4(\mathrm{e})$ & $0.0(\mathrm{~m})$ & $3.9(\mathrm{r})$ & $7.8(\mathrm{w})$ \\
& $17.3(\mathrm{~b})$ & $12.7(\mathrm{~g})$ & $8.3(\mathrm{n})$ & $12.2(\mathrm{~s})$ & $16.1(\mathrm{x})$ \\
& $25.6(\mathrm{c})$ & $21.0(\mathrm{~h})$ & $16.6(\mathrm{o})$ & $20.5(\mathrm{t})$ & \\
& $33.9(\mathrm{~d})$ & $29.3(\mathrm{k})$ & $24.9(\mathrm{p})$ & $28.8(\mathrm{u})$ & \\
& & $37.6(\mathrm{l})$ & $33.2(\mathrm{q})$ & & \\
\hline
\end{tabular}

$38 \%$ and the water content from 20 to $60 \%$. Casein was used as the protein source. As fat source a mixture based on fish oil was used. Every diet contained $10 \%$ dextrin and $6 \%$ premix (vitamin-mineral mixture). Dietary protein and fat levels are summarized in Table 2.

Fish were weighed every 2 weeks. Fish samples for analyses of body composition were taken at days $0,28,56$ and 84 . The experiments can be subdivided into three distinct periods of 4 weeks each.

In the framework of the model as described in the previous paper (Machiels and Henken, 1986) the following assumptions were made:

(1) The amino acid composition of $C$. gariepinus protein is identical to the average amino acid composition of Salvelinus protein given by Love (1970).

(2) Fish fat and dietary fat consist of tri-oleylglycerol only (TOG, $\mathrm{C}_{57} \mathrm{O}_{6} \mathrm{H}_{104}$ ).

(3) Glycerol synthesis is negligible.

(4) The chemical composition within the protein and fat fractions is constant.

(5) Ammonia is the only nitrogenous excretion product.

(6) All nucleotide triphosphates are interconvertible and can be expressed in terms of ATP.

(7) Transportation of metabolites across a biomembrane costs 1 mole ATP per mole metabolite.

In the framework of the model as presented in this paper two assumptions are added.

(8) The digestibility coefficients of different nutrients are set at $95 \%$ for protein, fat and dextrin. Casein and fish oil are highly digestible (Ogino and Chen, 1973; Machiels and Henken, 1985). Because C. gariepinus is an omnivorous fish, dextrin is considered to be highly digestible. The digestibility coefficients are independent of the feeding level.

(9) Micronutrients are present in sufficient amounts in all cases and thus do not restrict growth. A surplus is harmless. 
Biochemical reaction equations

The weight conversions of the biosynthetic reactions, using a feed composed of casein, fish oil and dextrin as usable ingredients, are:

for casein:

synthesis of body protein

$1 \mathrm{~g}$ casein $+0.40 \mathrm{~g} \mathrm{O}_{2} \rightarrow 0.61$ g protein +0.15 g glucose $+0.48 \mathrm{~g} \mathrm{CO}_{2}+0.045 \mathrm{~g} \mathrm{H}_{2} \mathrm{O}+0.020$ mole ATP

gluconeogenesis

$1 \mathrm{~g}$ casein $+0.80 \mathrm{~g} \mathrm{O}_{2}+0.06 \mathrm{~g} \mathrm{H}_{2} \mathrm{O} \rightarrow 0.58 \mathrm{~g}$ glucose $+1.0 \mathrm{~g} \mathrm{CO}_{2}+0.163 \mathrm{~g} \mathrm{NH}_{3}+0.12$ mole ATP

for fat $(\mathrm{TOG}=$ trioleylglycerol $)$ :

synthesis of body fat (directly)

$0.96 \mathrm{~g}$ oleine $+0.10 \mathrm{~g}$ glycerol +0.014 mole ATP $\rightarrow 1 \mathrm{~g}$ TOG $+0.06 \mathrm{~g} \mathrm{H}_{2} \mathrm{O}$

synthesis of body fat (via acetyl-CoA)

$0.96 \mathrm{~g}$ oleine $+0.10 \mathrm{~g}$ glycerol +0.047 mole ATP

$$
+1.133 \mathrm{~g} \mathrm{O}_{2} \rightarrow 0.618 \mathrm{~g} \mathrm{TOG}+1.11 \mathrm{~g} \mathrm{CO}_{2}+0.411 \mathrm{~g} \mathrm{H}_{2} \mathrm{O}
$$

for dextrin ( $1 \mathrm{~g}$ dextrin $=1.11 \mathrm{~g}$ glucose $)$ :

synthesis of body fat

$1 \mathrm{~g}$ glucose $+0.22 \mathrm{~g} \mathrm{O}_{2} \rightarrow 0.29 \mathrm{~g} \mathrm{TOG}+0.63 \mathrm{~g} \mathrm{CO}_{2}+0.30 \mathrm{~g} \mathrm{H}_{2} \mathrm{O}$

The weight conversions for the oxidation reactions are:

for body protein:

$1 \mathrm{~g}$ protein $+1.47 \mathrm{~g} \mathrm{O}_{2} \rightarrow 1.98 \mathrm{~g} \mathrm{CO}_{2}+0.204 \mathrm{~g} \mathrm{NH}_{2}$ $+0.27 \mathrm{~g} \mathrm{H}_{2} \mathrm{O}+0.248$ mole ATP $+0.01 \mathrm{~g} \mathrm{H}_{2} \mathrm{~S}$

for body fat:

$1 \mathrm{~g} \mathrm{TOG}+2.9 \mathrm{~g} \mathrm{O}_{2} \rightarrow 2.8 \mathrm{~g} \mathrm{CO}_{2}+1.1 \mathrm{~g} \mathrm{H}_{2} \mathrm{O}+0.51$ mole ATP

\section{Parameters calibrated}

The value of some parameters was adopted from the calibration described in the previous paper (Machiels and Henken, 1986):

(1) Routine metabolic rate is 0.0012 mole ATP $\cdot \mathrm{g}^{-0.8} \cdot$ day $^{-1}$ at $25^{\circ} \mathrm{C}$.

(2) $Q_{10}$ value is 2.0 between 20 and $30^{\circ} \mathrm{C}$.

(3) Feeding metabolism is 0.012 mole ATP/g feed consumed, which corresponds to 0.03 mole ATP per gram of digestible protein (taking digestibility into account). 


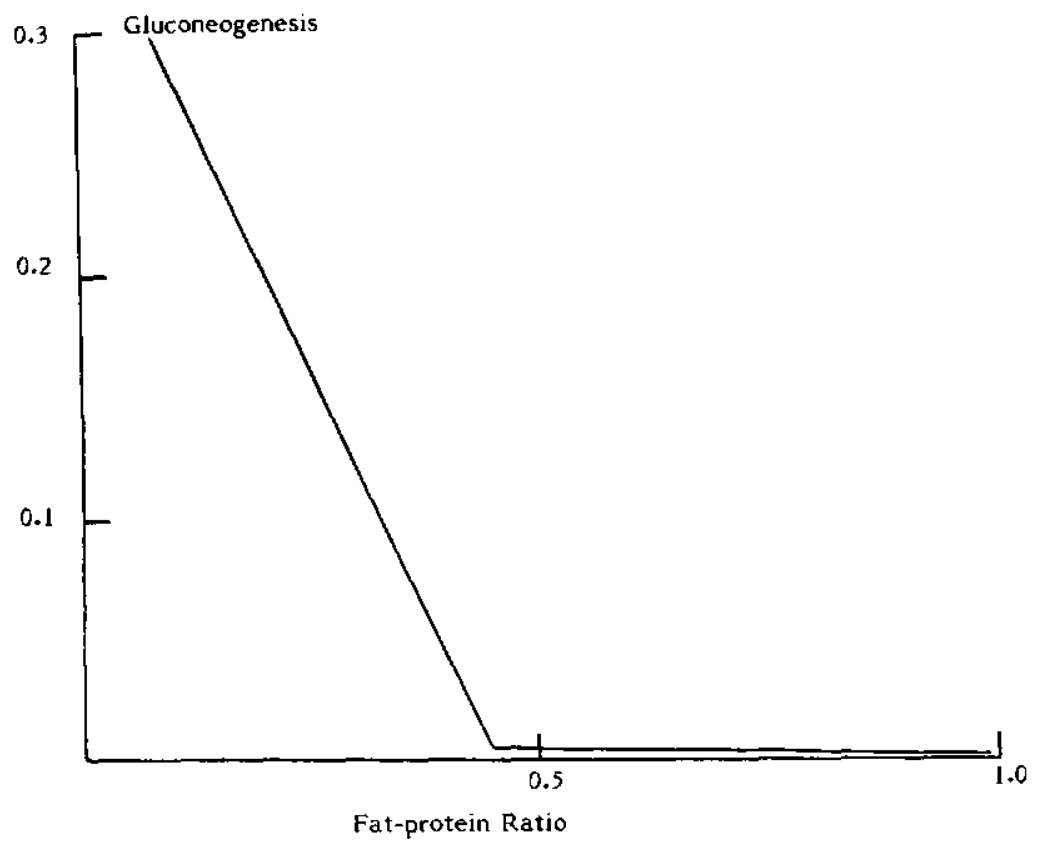

Fig. 1. The part of the dietary protein used for gluconeogenesis and the ratio of fat to protein in the feed

(4) The part of the energy requirement that is supplied by oxidation of body fat is related to the body composition.

To make the model applicable also for different feed compositions, the data of Henken et al. (1986) were used to calibrate:

(5) The part of the feed protein which is used for gluconeogenesis: from the amount of protein and fat absorbed it can be calculated how much body protein and fat can be synthesized if no dietary protein is used for gluconeogenesis. From the experimental data it is known how much body protein and fat is retained in reality. The part of the dietary protein used for gluconeogenesis was set such that the ratio of fat to protein gain of the model output is similar to the observed ratio of fat to protein gain. The result of this procedure is shown in Fig. 1 . The values on the $y$ axis represent the part of the dietary protein used for gluconeogenesis. The values on the $x$ axis represent the ratio of fat to protein in the feed. The carbohydrates in the feed nutrients were converted to fat for the calculation of the ratio, using a factor $0.3 \mathrm{~g}$ fat per $\mathrm{g}$ of carbohydrate. A decreasing amount of the protein is used for gluconeogenesis when the fat to protein ratio increases. Below a ratio of about 0.45 this decrease becomes considerably marked.

In the first instance this was the only added parameter calibrated. Still there 
remained a large difference between the model and observed results. Therefore two more parameters were calibrated:

(6) Amount of feed spilled: when fish are fed crumbled semi-moist diets, some of the feed will not be eaten. Particles may remain unnoticed or may disintegrate fast. Also manipulating particle size is hardly possible with semimoist diets. Because optimal particle size increases with fish weight, it can be expected that the more feed remains uneaten the bigger are the fish. In the model the amount of feed spilled is set at $5 \%$ of the amount given in the case of fish of $40 \mathrm{~g}$. This was increased linearly up to $15 \%$ for fish of $150 \mathrm{~g}$ and fixed at $15 \%$ for bigger fish.

(7) Maximum feed intake: in the first instance maximum feed intake was only related to fresh body weight and temperature. It was noticed, however, that when the fish grew fatter, the difference between model and observed results increased. Apparently fatter fish consume less than leaner fish of the same body weight. The same correlation between fat percentage of fish biomass and feed consumed is found for fish in nature (Shul'man, 1974). In the model maximum feed intake was therefore related to the fat content of the fish (Fig. 2) as well as to fresh body weight and water temperature.

The results of the final fitting are presented in Figs. 3, 4 and 5. The bisectors in these figures represent perfect agreement between observed $(y)$ and simulated $(x)$ fresh weight gain, protein gain and fat gain respectively. The coefficient of variation $\left[\left(\sqrt{\sum(y-x)^{2} /(n-2)}\right) / \bar{y}\right]$ for fresh weight gain, protein gain and fat gain was about $0.18,0.23$ and 0.32 , respectively. The C.V. for fat gain is high, because the fat gain was overestimated at $29^{\circ} \mathrm{C}$ and underestimated at $24^{\circ} \mathrm{C}$.

\section{DATA USED TO TEST THE MODEL}

To test the validity of the adapted model, simulated output should be compared with experimental results not used during the modelling procedures. Such independently obtained results were available from balance respiration experiments at $27.5^{\circ} \mathrm{C}$ (Machiels and Henken, 1985). During three 56-day experiments five dietary protein levels were tested using a different dietary metabolizable energy level in each experiment. Protein content of the diets varied from 20 to $40 \%$ and fat content from 4 to $29 \%$. The feed composition with respect to content of casein and fat is summarized in Table 3 . The dietary dextrin contents were 5,10 and $15 \%$ at the respective metabolizable energy levels of $8.4,12.6$ and $16.4 \mathrm{~kJ} / \mathrm{g}$.

In all three experiments the fish were fed daily about $2 \%$ of their fresh body weight. The feed was provided in a pelleted form (dry matter content about $90 \% 2-\mathrm{mm}$ pellets). At days 0,28 and 56 the fish were weighed and sampled for analysis of body composition. According to this schedule each experiment can be subdivided into two distinct periods of 4 weeks each. Fresh body weight 


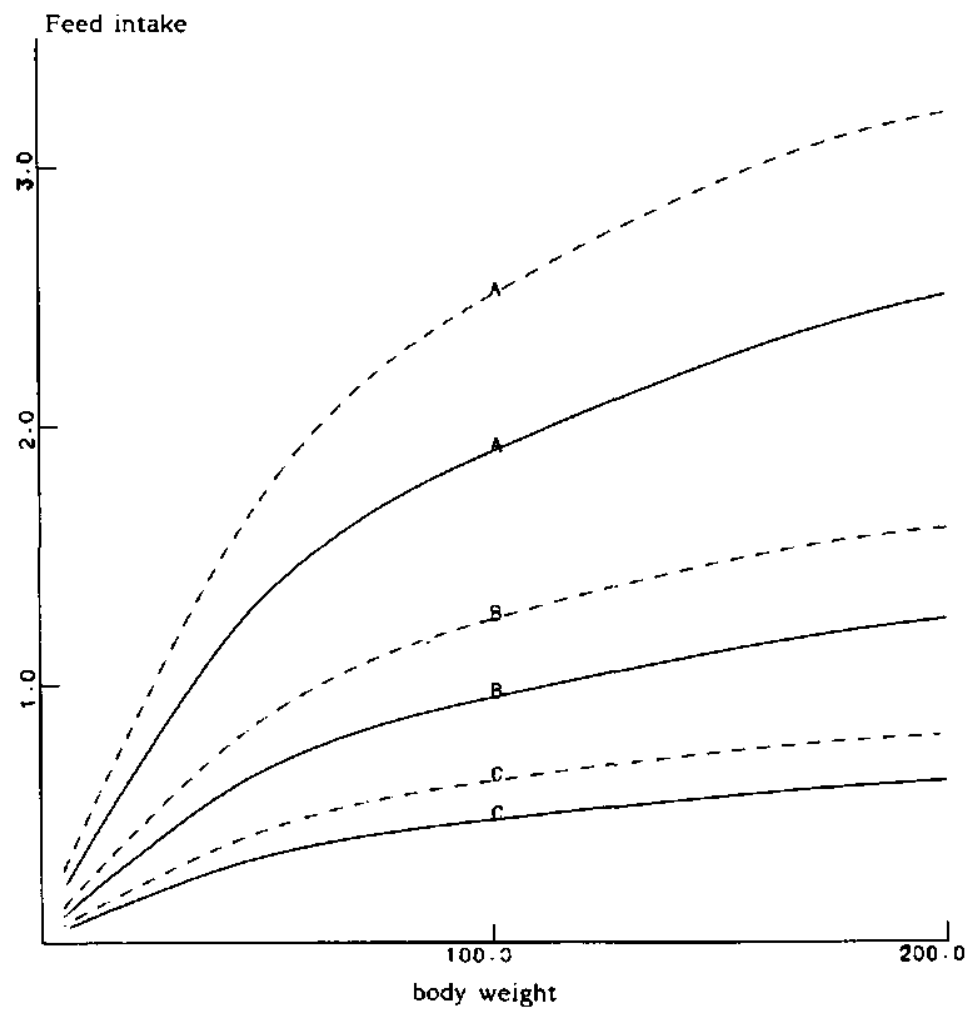

Fig. 2. The maximum feed intake $(\mathrm{g})$ in relation to fresh body weight at $24^{\circ} \mathrm{C}$ (solid lines) and $29^{\circ} \mathrm{C}$ (broken lines). A, Fat content $<7 \%$; B, Fat content $=9 \%$; C, Fat content $=11 \%$.

and fat percentage at days 0 and 28 were used as starting points for the simulation of the two respective periods. Feeding level, feed composition and temperature chosen were similar to the experimental conditions. Because a dry pellet feed was used, it is assumed that no feed was spilled.

\section{RESULTS AND DISCUSSION}

Simulation output and experimental results differed systematically for fat gain and oxygen consumption. The predictions for fat gain were too high, those for oxygen consumption too low. This difference can be reduced by assuming a higher respiration rate or assuming de novo synthesis of fish fat via acetylCoA.

A higher respiration rate will result in a greater breakdown of body fat and higher oxygen consumption. This is possible if the fasting and/or feeding metabolic rates in these experiments are higher than in the experiments which were used for calibration. 


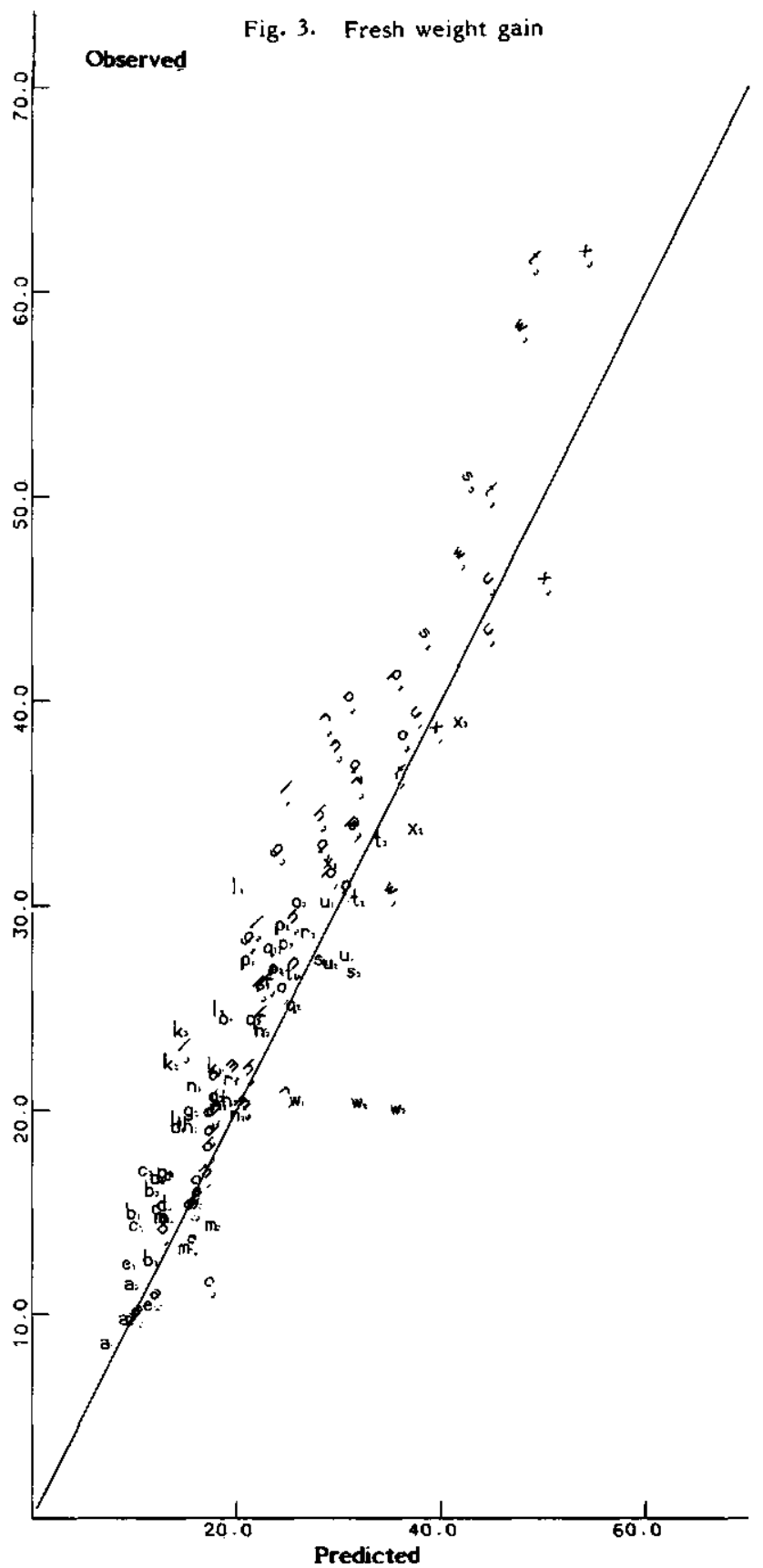

Figs. 3 to 5. Predicted output from the simulation model and experimental results of fresh weight gain, protein gain and fat gain ( $\mathrm{g} / 28$ days) used for parameterization. The symbols for the different diets are presented in Table 2. Vertical symbols represent results at $24^{\circ} \mathrm{C}$. The sloping symbols represent results at $29^{\circ} \mathrm{C}$. The index 1,2 or 3 represents the experimental period. 
42

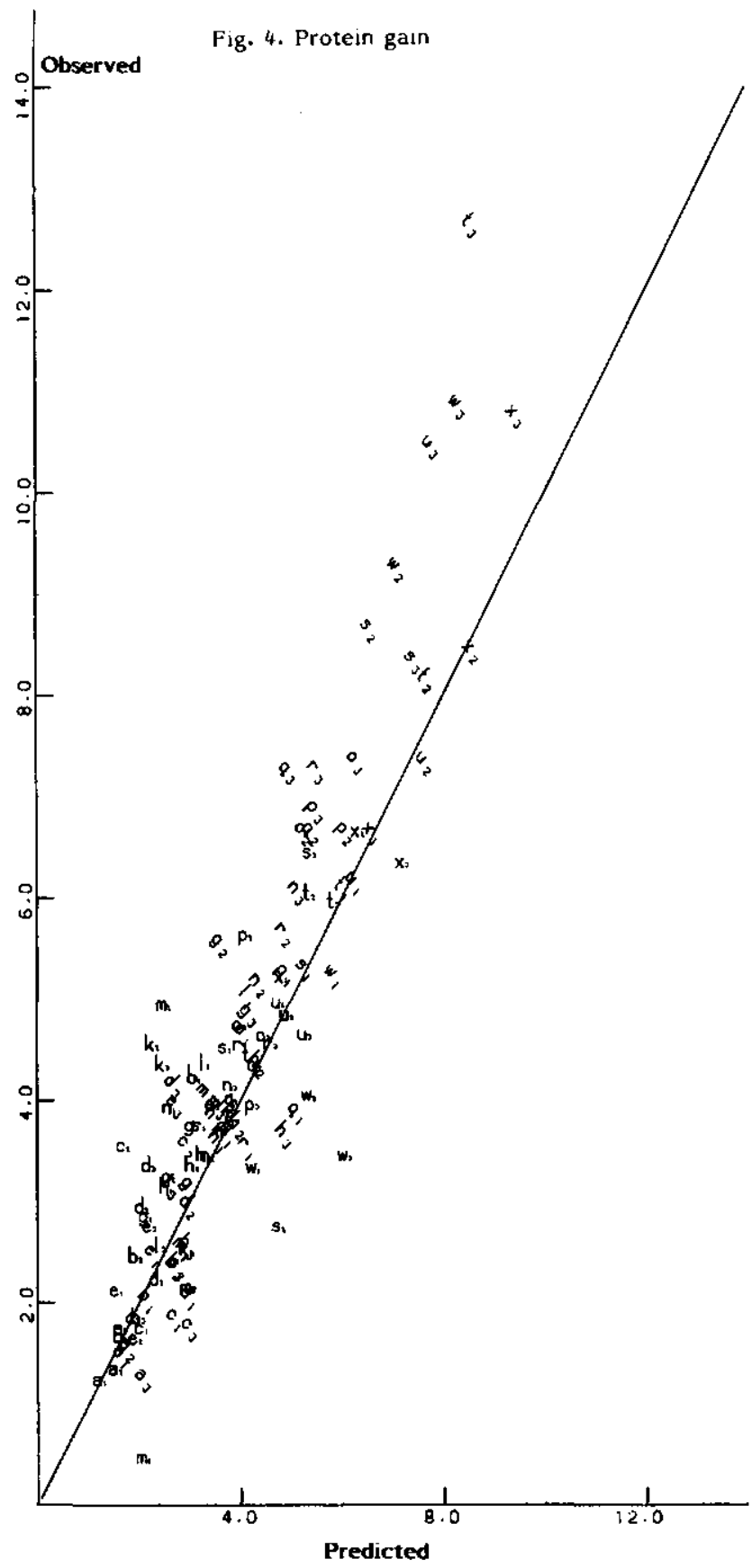




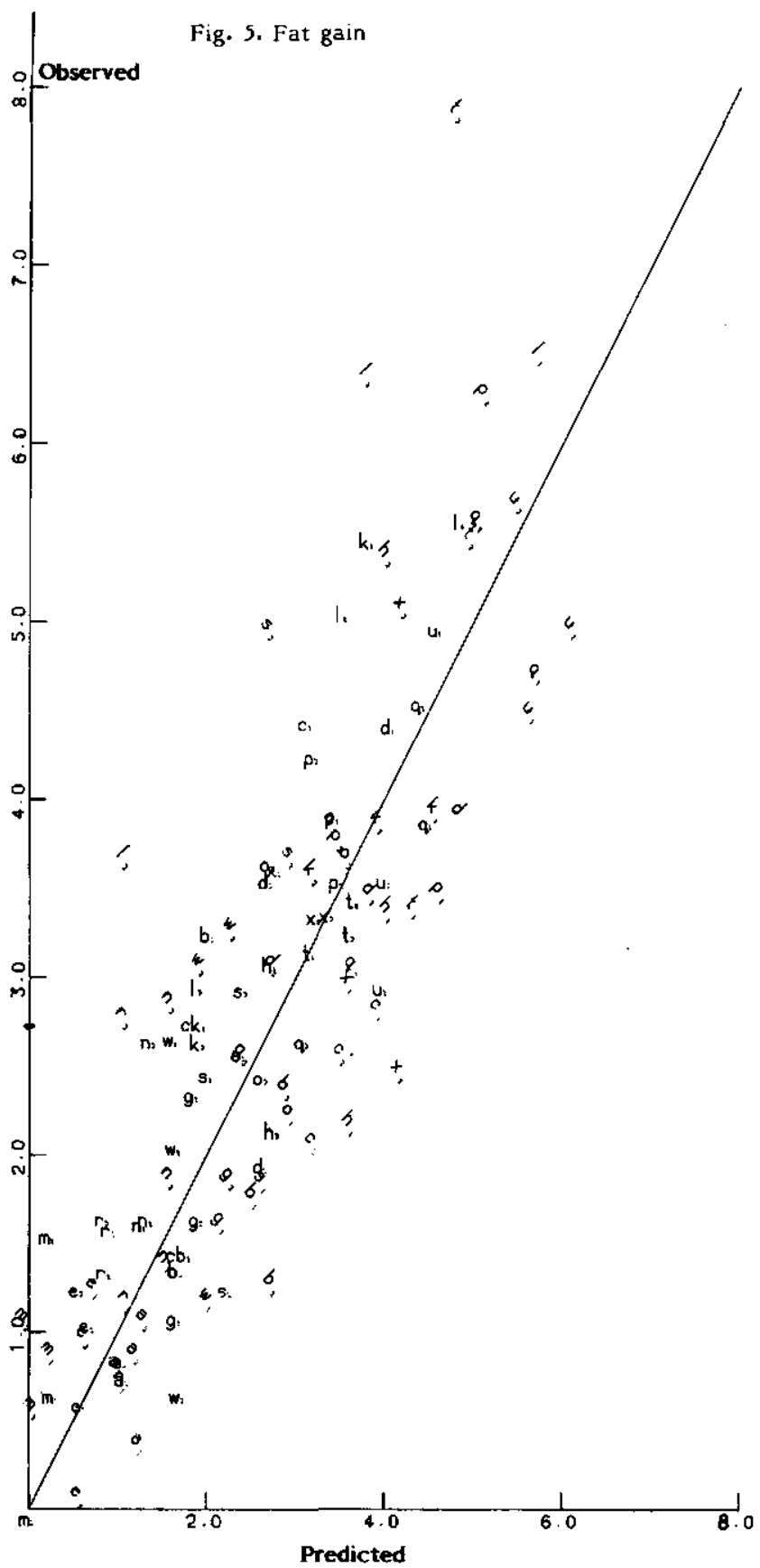


TABLE 3

The casein and fat contents (\%) of the diets in the experiments used for testing. The letters are the symbols used in Figs. 6-9 for the various diets

\begin{tabular}{llrrrr}
\hline & \multicolumn{1}{c}{ Casein } & & & & \\
\cline { 2 - 6 } & 20 & 25 & 30 & 35 & 40 \\
\hline Fat & $11.1(\mathrm{a})$ & $8.9(\mathrm{~b})$ & $6.7(\mathrm{c})$ & $4.4(\mathrm{~d})$ & $4.4(\mathrm{e})$ \\
& $20.0(\mathrm{~g})$ & $17.8(\mathrm{~h})$ & $15.6(\mathrm{k})$ & $13.3(1)$ & $11.1(\mathrm{~m})$ \\
& $28.9(\mathrm{n})$ & $26.7(\mathrm{o})$ & $24.4(\mathrm{p})$ & $22.2(\mathrm{r})$ & $20.0(\mathrm{~s})$ \\
\hline
\end{tabular}

The main difference between the two experiments is that a pelleted feed was provided in the experiment used for testing. During the pelleting process the temperature of the feed is increased. A high temperature may cause a reaction between amino acids and sugars in the feed (Maillard reaction). The products of this reaction are absorbed by the fish but not utilized (Plakas et al., 1985). A lower availability of glucose and amino acids will decrease liponeogenesis. The breakdown and excretion of the reaction products will increase respiration.

The novo synthesis of fish fat will occur when dietary and fish fat composition are not identical. Results of analysis of dietary fat and fish fat are presented in Table 4. Dietary fat contains less saturated and mono-unsaturated fatty acids than fat of $C$. gariepinus. Dietary fat contains more poly-unsaturated fatty acids. This difference in fatty acid composition indicates that at least part of the fish fat originates from the novo synthesis. It is impossible to quantify the effect of a Maillard reaction at this moment. Because both alternatives will have the same result, it was assumed that all fat is synthesized de novo.

The test results are presented in Figs. 6, 7, 8 and 9 for fresh weight gain, protein gain, fat gain and oxygen consumption, respectively. The bisectors represent perfect agreement between observed ( $y$ axis) and predicted ( $x$ axis) values. The observed and predicted values do match reasonably well. Moreover, the relations in the predicted results between on the one hand fresh weight

\section{TABLE 4}

Percent fatty acid composition of feed fat and fish fat

\begin{tabular}{lll}
\hline Fatty acid & \multicolumn{2}{l}{ Lipid source } \\
\cline { 2 - 3 } & Feed fat & Fish fat \\
\hline \% SAT (sum of \% $\mathrm{C}_{14.0}, \mathrm{C}_{18.0}$ and $\mathrm{C}_{18.0}$ ) & 17.8 & 34.5 \\
\% MONO (sum of $\% \mathrm{C}_{16.1}, \mathrm{C}_{18.1}, \mathrm{C}_{20.1}$ and $\mathrm{C}_{24.1}$ ) & 23.8 & 32.0 \\
\% PUFA (sum of \% $\mathrm{C}_{18.2}, \mathrm{C}_{20.0}, \mathrm{C}_{20.5}, \mathrm{C}_{22.5}$ and $\mathrm{C}_{22.8}$ ) & 37.3 & 12.3 \\
\hline
\end{tabular}




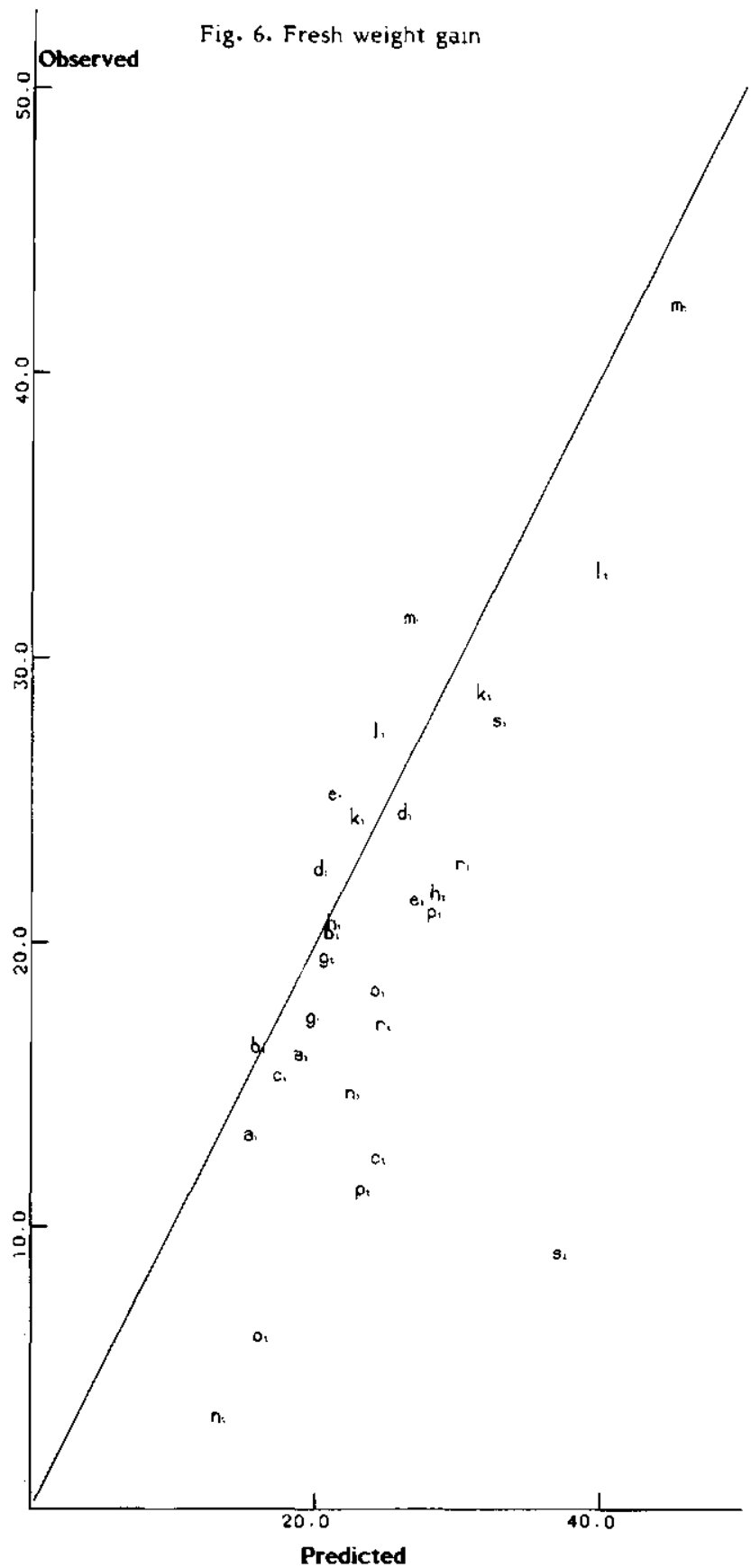

Figs. 6 to 9. Predicted output from the simulation model and experimental results of fresh weight gain, protein gain, fat gain ( $\mathrm{g} / 28$ days) and oxygen consumption ( $1 / 28$ days) used for testing. The symbols for the different diets are presented in Table 3 . The index 1 or 2 represents the experimental period. 


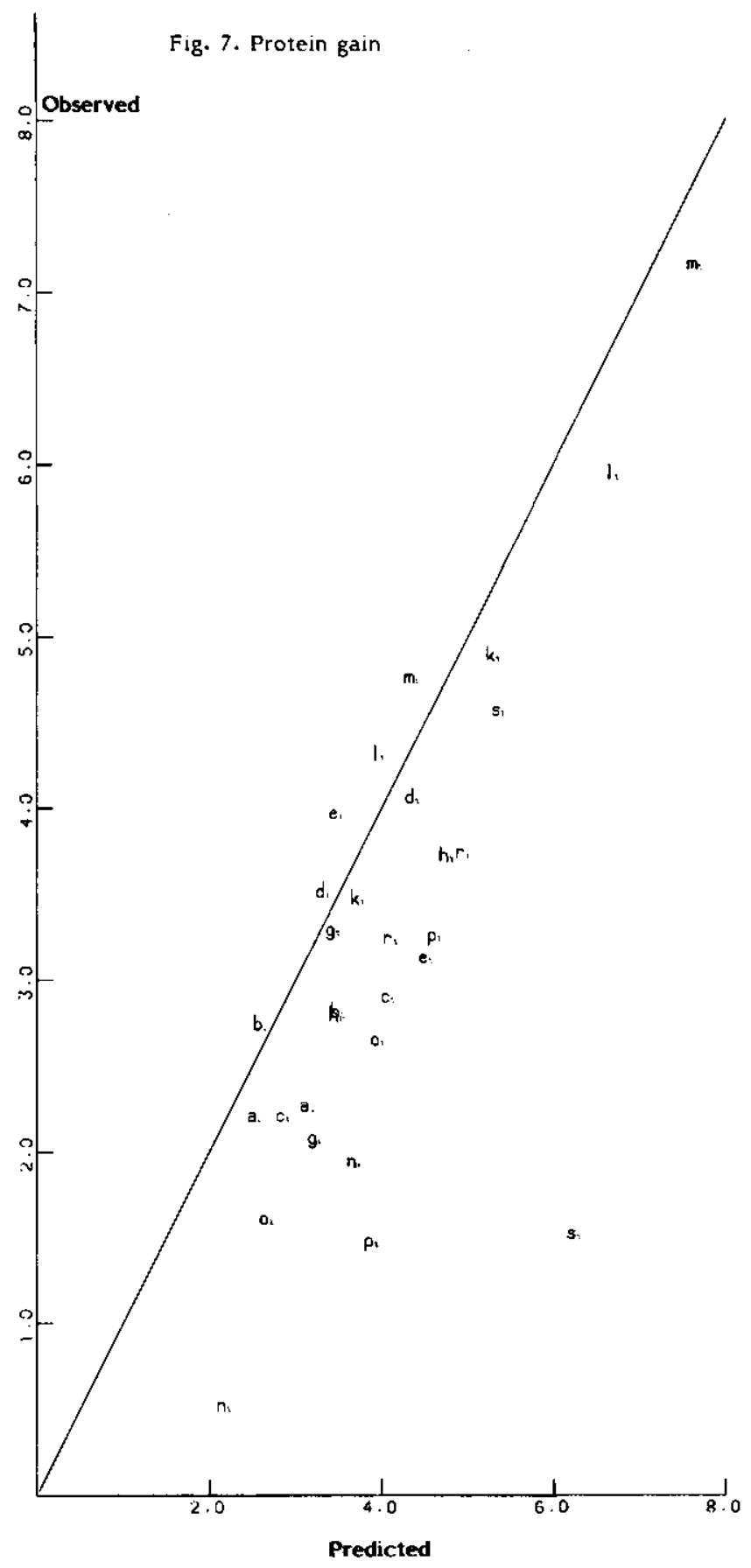




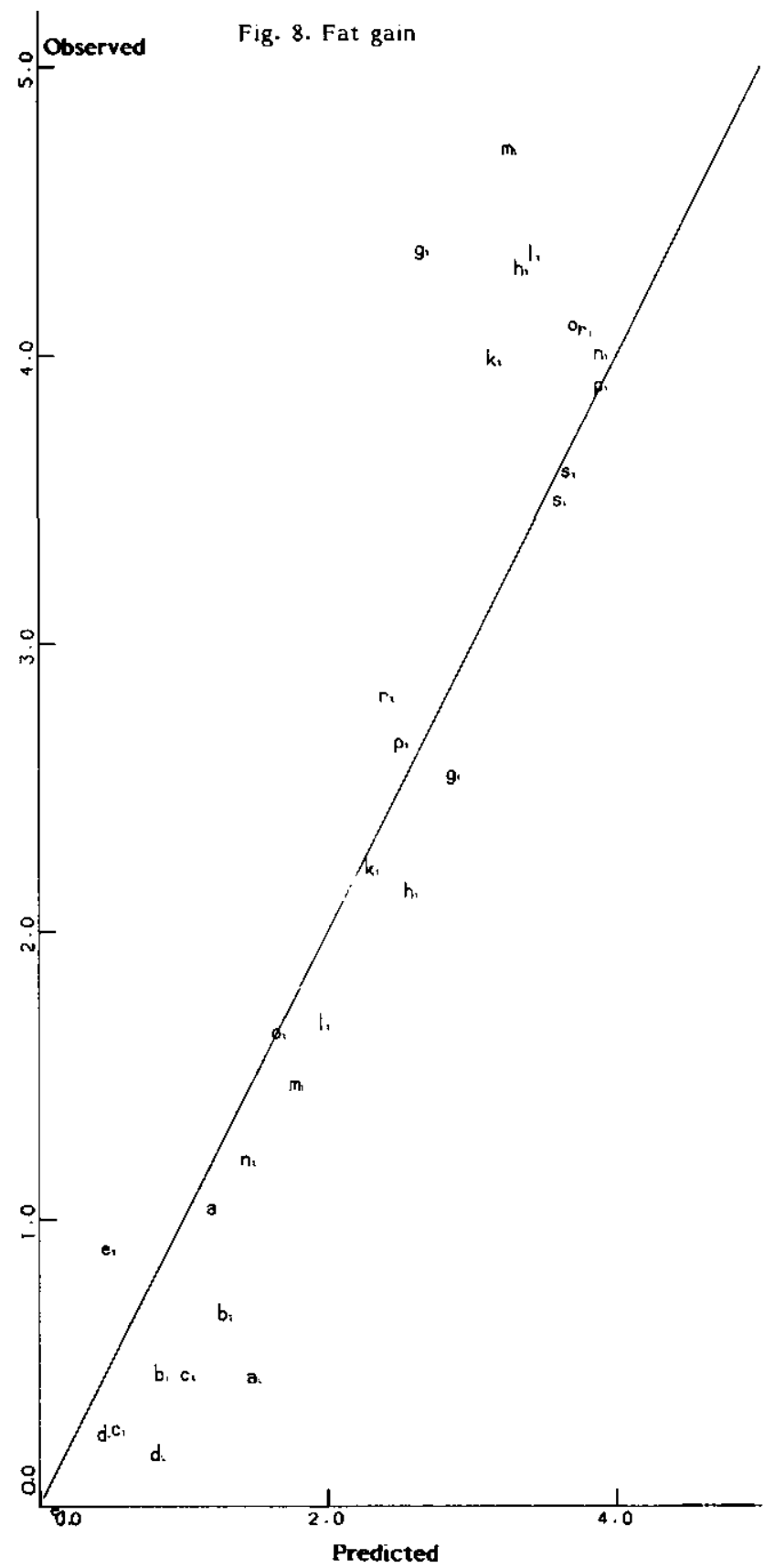




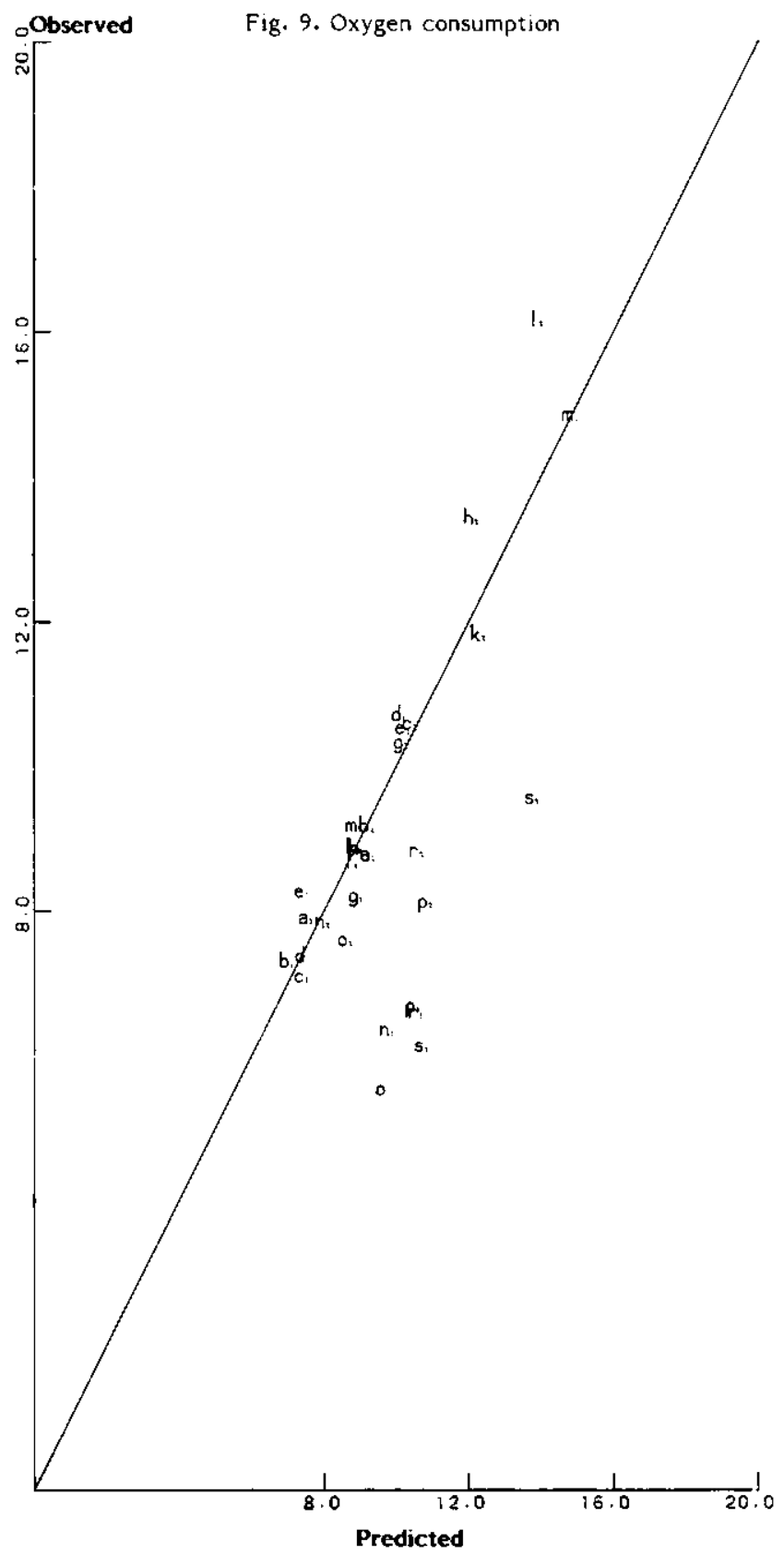


gain, protein gain, fat gain and oxygen consumption and on the other hand protein and fat intake are in agreement with those observed. Fresh weight gain and protein gain are determined in the first place by the amount of protein consumed. They increase at higher intake levels. At a certain protein intake level, however, fresh weight gain and protein gain are also determined by the amount of fat consumed. When more fat is offered, less protein will be used for gluconeogenesis, resulting in a higher protein gain and an increase of fresh weight gain.

At extremely high dietary fat levels (22\% or more) fresh weight gain decreases because of a reduced feed intake. This reduction in feed intake is caused by the rapidly increasing fat percentage in the fish biomass at such high dietary fat levels. A decrease in feed consumption was also noticed during the experiments, especially in the second period of the last experiment, in which the high-fat diets were tested (Machiels and Henken, 1985).

The effect of carbohydrates on the growth parameters was confounded with the effect of fat. The highest carbohydrate levels (15\% dextrin) coincided with the highest fat levels.

In the model a single value, the protein digestibility coefficient, was used to calculate the amount absorbed of each amino acid. However, differences in digestibilities between individual amino acids may be large, especially in ingredients with a low protein content (Wilson et al., 1981). When digestibilities of the individual amino acids are known, they can easily be incorporated in the model.

Knowledge about dietary and fish fatty acid composition would allow a more accurate calculation of the conversion of dietary fat into fish fat. It is unknown which fatty acids are essential for $C$. gariepinus. This may be important because the ability to chain elongate and desaturate differs considerably between species (Love, 1980). In the framework of this model, it would be an improvement if a distinction could be made between conversion to phospholipids and conversion to triglycerides. Essential fatty acids are mostly associated with the phospholipids. The phospholipids are generally considered to be structural or functional lipids, being incorporated mostly in cell membranes and subcellular particles. The triglycerides are more often storage lipids and reflect the fatty acid composition of a diet to a greater extent than do the phospholipids (Castell, 1979). This means that triglycerides can more often be made directly from dietary fat, while incorporation of phospholipids may need more transformation of dietary fat.

The amount of storage lipids increases with high-fat diets. A reflection of different pathways for biosynthesis of body fat is found in the oxygen consumption. If it is assumed that fat synthesis is completely de novo, the oxygen consumption is overestimated on high-fat diets.

It is concluded that the simulation model adapted from Machiels and Henken (1986) estimates satisfactorily the effects of feed composition, in partic- 
ular protein and fat, on growth and energy metabolism. C. gariepinus seems to regulate its feed intake by the fat content of the biomass. A fat fish will eat less than a leaner fish of the same weight. Regulation of the feed intake on the basis of dietary gross energy is generally accepted (Cowey and Sargent, 1979). Both hypotheses will in the end have the same result. A higher energy diet will increase the fat percentage of the fish. The fish will react by eating less. The difference between the two hypotheses is that in the model the importance of the feeding strategy is expressed by its effect on body composition and not by a feed characteristic.

\section{REFERENCES}

Babiker, M.M., 1984. Aspects of the biology of the catfish Clarias lazera (Cuv. \& Val.) related to its economic cultivation. Hydrobiologia, 110: 295-304.

Brett, J.R., 1979. Environmental factors and growth. In: W.S. Hoar, D.J. Randall and J.R. Brett (Editors), Fish Physiology, Vol. VIII. Bioenergetics and Growth. Academic Press, New York, pp. 599-675.

Castell, J.D., 1979. Review of lipid requirements of finfish. In: J.E. Halver and K. Tiews (Editors), Finfish Nutrition and Fish Feed Technology, Vol. I. Heenemann, Berlin, pp. 59-84.

Cho, C.Y., Bayley, H.S. and Slinger, S.J., 1976. Energy metabolism in growing rainbow trout: partition of dietary energy in high protein and high fat diets. In: M. Vermorel (Editor), Proc. 7th Symp. on Energy Metabolism, Vichy, France. Bussac, Clermont-Ferrand, pp. 299-302.

Cho, C.Y., Slinger, S.J. and Bayley, H.S., 1982. Bioenergetics of salmonid fishes: energy intake, expenditure and productivity. Comp. Biochem. Physiol., 73B: 25-41.

Cowey, C.B. and Sargent, J.R., 1979. Nutrition. In: W.S. Hoar, D.J. Randall and J.R. Brett (Editors), Fish Physiology, Vol. VIII. Bioenergetics and Growth. Academic Press, New York, pp. 1-69.

Henken, A.H., Machiels, M.A.M., Dekker, W. and Hogendoorn, H., 1986. The effect of dietary protein and energy content on growth rate and feed utilization of the African catfish Clarias gariepinus (Burchell 1822). Aquaculture, 58: 55-74.

Hogendoorn, H., 1983. The African catfish (Clarias lazera C.\&V., 1840) - A new species for aquaculture. Dissertation, Agricultural University, Wageningen, The Netherlands, 135 pp.

Hogendoorn, H., Janssen, J.A.J., Koops, W.J., Machiels, M.A.M., Van Ewijk, P.H. and Van Hees, J.P., 1983. Growth and production of the African catfish, Clarias lazera (C. \& V.). II. Effects of body weight, temperature and feeding level in intensive tank culture. Aquaculture, 34: 265-285.

Jobling, M., 1983. Toward an explanation of specific dynamic action (SDA). J. Fish Biol., 23: 549-555.

Love, R.M., 1970. The Chemical Biology of Fishes. Academic Press, New York, $547 \mathrm{pp.}$

Love, R.M., 1980. The Chemical Biology of Fishes. Volume 2: Advances 1968-1977. Acedemic Press, New York, 943 pp.

Machiels, M.A.M. and Henken, A.M., 1985. Growth rate, feed utilization and energy metabolism of the African catfish, Clarias gariepinus (Burchell, 1822), as affected by dietary protein and energy content. Aquaculture, 44: 271-284.

Machiels, M.A.M. and Henken, A.M., 1986. A dynamic simulation model for growth of the African catfish, Clarias gariepinus (Burchell 1822). I. Effect of feeding level on growth and energy metabolism. Aquaculture, 56: 29-52.

Millikin, M.R., 1982. Qualitative and quantitative nutrient requirements of fishes: a review. Fish. Bull., 80: 655-686. 
Ogino, C. and Chen, M.S., 1973. Protein nutrition in fish. III. Apparent and true digestibility of dietary proteins in carp. Bull. Jpn. Soc. Sci. Fish., 39: 649-651.

Plakas, S.M., Lee, T., Wolke, R.E. and Meade, T.L., 1985. Effect of Maillard reaction on protein utilization and plasma amino acid response by rainbow trout (Salmo gairdneri). J. Nutr., 115: 1589-1599.

Shul'man, G.E., 1974. Life Cycles of Fish. Wiley, New York (transl. from Russian), 258 pp.

Wilson, R.P., Robinson, E.H. and Poe, W.E., 1981. Apparent and true availability of amino acids from common feed ingredients for channel catfish. J. Nutr., 111: 923-929.

Zeitoun, I.H., Ullrey, D.E., Magee, W.T., Gill, J.L. and Bergen, W.G., 1976. Quantifying nutrient requirement of fish. J. Fish. Res. Board Can., 33: 167-172. 


\title{
A Dynamic Simulation Model for Growth of the African Catfish, Clarias gariepinus (Burchell 1822) III. The Effect of Body Composition on Growth and Feed Intake
}

\author{
M.A.M. MACHIELS and A.A. VAN DAM \\ Department of Fish Culture and Fisheries, Agricultural University, P.O. Box 338, Wageningen \\ (The Netherlands)
}

(Accepted 19 October 1986)

\section{ABSTRACT}

Machiels, M.A.M. and Van Dam, A.A., 1987. A dynamic simulation model for growth of the African catfish, Clarias gariepinus (Burchell 1822). III. The effect of body composition on growth and feed intake. Aquaculture, 60: 55-71.

A feeding experiment was conducted in aquaria to study the effect of body composition on growth and feed intake of Clarias gariepinus. Fishes weighing about $20 \mathrm{~g}$ were fed diets with different protein to fat ratios. Diet A contained $60 \%$ protein, $7 \%$ fat and $19 \%$ carbohydrate. The composition of diet B was $20 \%$ protein, $7 \%$ fat and $54 \%$ carbohydrate. After 4 weeks the mean fish weight per tank amounted $33.2 \pm 1.5$ and $27.5 \pm 1.4 \mathrm{~g}$ for fish fed diets $A$ and $B$, respectively, while the fat content of the fish was $3.6 \pm 0.3$ and $6.1 \pm 0.4 \%$.

During two consecutive periods of 21 days both the lean and the fat fish were fed $\operatorname{diet} A$ or $B$ at five feeding levels. The feeding levels ranged from maintenance to above satiation. Fresh weight gain, protein gain and fat gain were higher with increasing feed ration, until a maximum was reached where extra feed did not result in more gain. This maximum gain was higher for diet $A$. Feeding with this high-protein diet resulted in better feed conversions compared with diet B. Within one diet, lean fish had a higher maximum growth rate compared to fat fish due to a higher feed consumption. Below the maximum gain, fat fish showed a slightly better conversion efficiency when fed with diet $A$.

A explanatory model, for simulating growth of $C$. gariepinus, was extended in accordance with these experimental findings. It is assumed that the maximum consumption is regulated by both lipostatic and glucostatic mechanisms. The relevant parameter values were fitted with results obtained in the second experimental period. The adjusted model was tested by comparing simulation with experimental results found in the third period. The model gives good results for feeding levels providing sub-maximum gain. At the highest feeding levels of diet A, fed to initially fat fish, the model overestimated gain. The model was used to predict fresh weight gain of $C$. gariepinus fed diets with different compositions. 


\section{INTRODUCTION}

Recently a model has been presented which simulates growth and energy metabolism of Clarias gariepinus (Burchell 1822) (Machiels and Henken, 1986, 1987). Knowledge and information from different disciplines were integrated to develop this explanatory growth model. A possible use of the model is the evaluation of different production alternatives and of interactions between feed and environmental factors.

The model gives satisfactory results in cases where feed composition is constant and different feed rations are given (Machiels and Henken, 1986). The model was also tested for differences in feed composition by comparing simulated results with experimental results for $C$. gariepinus fed different diets (Machiels and Henken, 1987). From these results it became obvious that, for successful application of the model under such circumstances, the model should include the assumption that body composition influences maximum feed intake.

The implication of such an assumption is of great practical value: diet composition will influence maximum feed intake, and therefore feeding history can affect growth results to quite an extent due to differences in body composition of the fish. Since there are no data available to support this assumption, an experiment was carried out to determine the effects of initial body composition and feed composition on fresh weight gain, protein gain and fat gain in relation to the feed ration.

The experiment was conducted in three consecutive periods. During the first period fish were fed diets with different protein to fat ratios in order to obtain fish with more or less the same body weight but with different body composition. The experimental results obtained with these fish during the second period were used to fit relevant parameter values for the simulation model. Finally, the results of the third period as well as of the first period were used to test the model thus adjusted.

\section{MATERIALS AND METHODS}

\section{Experimental fish and feed}

The experimental fish (full sibs) were obtained by artificial reproduction, using the method described by Hogendoorn $(1979,1980)$ and Hogendoorn and Vismans (1980). During the first 2 weeks after hatching the fish were fed with nauplii of Artemia salina and subsequently with a commercial trout diet (Trouw $\&$ Co., Putten, The Netherlands), according to the recommendations for $C$. gariepinus (Hogendoorn et al., 1983). At a mean fish weight of $20 \mathrm{~g}$ ( at 80 days after hatching) the fish were transferred to the experimental tanks.

Two pelleted diets were used in the experiment. Diet A was protein-rich and had a low carbohydrate content. Diet B was carbohydrate-rich and had a low 
TABLE 1

Compositon of the experimental diets

\begin{tabular}{lcc}
\hline & \multicolumn{2}{l}{ Diet code } \\
\cline { 2 - 3 } $\begin{array}{l}\text { Ingredients } \\
\text { (g/100 g) }\end{array}$ & $\mathrm{A}$ & $\mathrm{B}$ \\
\hline Herring meal & 30 & 8 \\
Meat meal (<12\% fat) & 21.8 & 8 \\
Meat greaves ( $>16 \%$ fat) & 3 & - \\
Feather meal & 12 & - \\
Blood meal & 7.5 & 2 \\
Premix & 0.325 & 0.325 \\
Monocalcium phosphate & 0.4 & 6.7 \\
Soya flour & 6.8 & - \\
Wheat middlings & 15.8 & 40.1 \\
Extruded wheat & - & 29.5 \\
Whey powder & 2.5 & 2.5 \\
Choline chloride & 0.1 & 0.1 \\
Fish oil & - & 3.0 \\
& & \\
Chemical analysis components (\%) & 60.2 & 22.1 \\
Protein & 19 & 54 \\
Carbohydrate & 6.5 & 7.2 \\
Fat & 7.3 & 7.9 \\
Moisture & & \\
\hline
\end{tabular}

"Trouw \& Co., Putten, The Netherlands.

bCalculated.

protein content. The data on feed ingredients and composition are summarized in Table 1.

\section{Experimental facilities and procedure}

The experiment took place at $27.5^{\circ} \mathrm{C}$ in 150 -l glass aquaria, which are part of two recirculation systems with 20 aquaria each (Hogendoorn et al., 1983).

During the first period of 4 weeks the stocking density was 50 fish per aquarium. Diet A was provided to the fish in half of the aquaria and diet $B$ to the fish in the other half. The feeding levels, expressed as a percentage of the fresh body weight per day, amounted to $1.4 \%$ for $\operatorname{diet} A$ and $3.9 \%$ for diet $B$. In this way fish fed diet $A$ became leaner and those fed diet $B$ became fatter, while the fresh weight gains for both groups were expected to be the same.

After the first period a sample of fish was retained from each aquarium for analysis of body composition, reducing the number of fish to 35 per aquarium. Both sampled and remaining fish were weighed. The sampled fish were stored at $-18^{\circ} \mathrm{C}$ until analysis. Duplicate groups of fat as well as lean fish were 
assigned to one of five feeding levels, which ranged from maintenance to above satiation feeding, in such a way that duplicate groups of fish were divided over the two recirculation systems. Differences between duplicates therefore were confounded with differences between recirculation systems.

Feeding was done by hand in the afternoon. If the fish showed satiation behaviour in this short period, the remaining feed was provided continuously during the subsequent night using 'Scharflinger' conveyor belt feeders. Feed consumption during the night could not be monitored and possibly a part of the food was not eaten.

The above procedure was followed during the subsequent second and third periods, which each lasted 21 days. After the second period a sample of 10 fish was taken from each aquarium for body composition analyses. The remaining fish and the sampled fish were weighed. After the third period all remaining fish were weighed and taken as sample for body composition analyses.

Fish samples and samples of the diets were analyzed in duplicate for dry matter, crude protein (Kjeldahl- $\mathrm{N} \times 6.25$ ) and crude fat (hexane extraction).

\section{Statistical analysis of data}

The results of the experiment for the growth parameters fresh weight gain, protein gain and fat gain were examined by analysis of variance with the following factors: replicate, initial body composition, diet composition and the interaction of initial body composition and diet composition. The effect of feed ration on growth parameters was estimated with a regression equation (at each combination of initial body composition and diet composition). This regression is based on the assumption that the weight gain increases proportionally with the feed ration until a maximum weight gain is reached.

The following model was used:

$$
\underline{Y}_{i j k l}=\mu+B_{i}+C_{j}+F_{k}+(C \times F)_{j k}+A_{(: j k)}+\underline{e}_{i j k l}
$$

where

$\underline{Y}_{i j k l}=$ observed value $(\mathrm{g} / 21$ days $)$

$\mu=$ overall mean

$B_{i}=$ effect of $i$ th replicate $(i=1,2)$

$C_{j}=$ effect of $j$ th initial body composition $(j=1,2)$

$F_{k}=$ effect of $k$ th diet composition $(k=1,2)$

$(C \times F)_{j k}=$ two-way interactions between initial body composition and diet composition.

$A_{(j, k)}=$ regression of $Y$ on feed ration with each combination of initial body composition and diet composition

$\underline{e}_{i j k l}=$ random effect. 
The regression equation is as follows:

$$
\begin{array}{ll}
y-\bar{y}=-p \times a+b \times(x-\bar{x}) & \text { for } x_{1} \text { up to } x_{q} \\
y-\bar{y}=q \times a & \text { for } x_{q+1} \text { up to } x_{p+q}
\end{array}
$$

where

$y=$ parameter value $(\mathrm{g} / 21$ days $)$

$x=$ feed ration $(\mathrm{g} / 21$ days $)$

$p=$ number of points on the plateau of the curve

$q=$ number of points on the inclining part of the curve

$\bar{y}=$ mean $y$-value $\left(y_{1}\right.$ to $\left.y_{p+q}\right)$

$\bar{x}=$ mean $x$-value $\left(x_{1}\right.$ to $x_{q}$ )

$a, b=$ regression coefficients.

\section{RESULTS}

The average weight of the fish at the start and at the end of each period, amount of feed given and the body composition are presented in Table 2. Summaries of the results of the analysis of variance and of the regression analysis are given in Tables 3 and 4 , respectively.

The results of the second period will be presented first, and the data on fresh body weight gain, protein gain and fat gain in the third period will be discussed after comparison with the simulation results.

\section{Growth parameter responses}

The data obtained in the second period for fresh body weight gain, protein gain and fat gain in relation to the feed ration are summarized in Figs. 1, 2 and 3.

The effects of the initial body composition, diet composition and their interaction on weight gain and protein gain were significant; however, fat gain was only significantly influenced by initial body weight (Table 3 ).

Feeding level significantly influenced gain, whether in fresh body weight, protein or fat, which increased with increasing ration size at low feeding levels. Using diet A, feeding levels providing sub-maximum weight gain resulted, in fat fish, in slightly better feed conversion and protein utilization. However, in lean fish better feed conversion and protein utilization was obtained with diet $B$. In the case of initially lean fish, feeding levels providing sub-maximum fat gain resulted in a higher coefficient of the regression equation for $\operatorname{diet} A$. The regression coefficients for the two diets were similar in the case of fat fish. The 
TABLE 2

Experimental results of initial weight, final weight and body composition (in fresh material) of C. gariepinus fed five different feeding levels of two diets at $27.5^{\circ} \mathrm{C}$. Body composition of the fish at the beginning of the third period and at the end of the second period is identical

\begin{tabular}{|c|c|c|c|c|c|c|c|c|c|c|c|c|}
\hline \multirow{3}{*}{$\begin{array}{l}\text { Diet } \\
\text { code }\end{array}$} & \multicolumn{7}{|c|}{ Second period } & \multicolumn{5}{|c|}{ Third period } \\
\hline & \multirow{2}{*}{$\begin{array}{l}\text { Init. } \\
\text { wt. } \\
\text { (g) }\end{array}$} & \multicolumn{2}{|c|}{ Body comp. } & \multirow{2}{*}{$\begin{array}{l}\text { Final } \\
\text { wt. } \\
\text { (g) }\end{array}$} & \multicolumn{2}{|c|}{ Body comp. } & \multirow{2}{*}{$\begin{array}{l}\text { Feed } \\
\text { (g/ } \\
21 \text { day) }\end{array}$} & \multirow{2}{*}{$\begin{array}{l}\text { Init. } \\
\text { wt. } \\
\text { (g) }\end{array}$} & \multirow{2}{*}{$\begin{array}{l}\text { Final } \\
\text { wt. } \\
\text { (g) }\end{array}$} & \multicolumn{2}{|c|}{ Body comp. } & \multirow{2}{*}{$\begin{array}{l}\text { Feed } \\
\text { (g/ day) } \\
21 \text { da }\end{array}$} \\
\hline & & $\begin{array}{l}\text { prot. } \\
(\%)\end{array}$ & $\begin{array}{l}\text { fat } \\
(\%)\end{array}$ & & $\begin{array}{l}\text { prot. } \\
\text { (\%) }\end{array}$ & $\begin{array}{l}\text { fat } \\
(\%)\end{array}$ & & & & $\begin{array}{l}\text { prot. } \\
(\%)\end{array}$ & $\begin{array}{l}\text { fat } \\
(\%)\end{array}$ & \\
\hline $\mathbf{A}$ & 35.7 & 16.0 & 3.5 & 37.5 & 16.1 & 2.4 & 2.5 & 37.8 & 39.8 & 15.4 & 1.5 & 2.7 \\
\hline $\mathbf{A}$ & 35.2 & 16.0 & 3.7 & 36.2 & 16.1 & 2.2 & 2.4 & 36.9 & 38.0 & 16.0 & 1.7 & 2.6 \\
\hline A & 34.6 & 15.9 & 3.6 & 43.8 & 15.9 & 2.6 & 6.9 & 44.7 & 56.3 & 15.9 & 1.7 & 8.8 \\
\hline $\mathbf{A}$ & 34.8 & 16.2 & 3.5 & 43.4 & 15.6 & 2.8 & 6.9 & 44.9 & 59.2 & 16.0 & 2.0 & 8.9 \\
\hline A & 34.1 & 17.6 & 3.6 & 53.4 & 16.0 & 2.5 & 12.1 & 53.8 & 79.6 & 16.9 & 2.4 & 19.0 \\
\hline A & 31.3 & 17.6 & 3.7 & 48.9 & 15.9 & 2.8 & 11.2 & 49.7 & 76.7 & 16.4 & 2.5 & 17.5 \\
\hline $\mathbf{A}$ & 33.9 & 15.6 & 3.0 & 110.9 & 15.6 & 3.9 & 45.5 & 111.1 & 238.5 & 16.4 & 4.0 & 135.0 \\
\hline $\mathbf{A}$ & 31.7 & 16.0 & 3.4 & 95.5 & 16.0 & 3.7 & 44.8 & 101.2 & 220.4 & 17.3 & 4.2 & 132.6 \\
\hline A & 32.0 & 15.9 & 4.7 & 116.4 & 15.9 & 3.6 & 57.8 & 127.6 & 278.5 & 17.1 & 4.7 & 169.2 \\
\hline A & 31.9 & 16.3 & 3.5 & 107.3 & 15.8 & 3.9 & 58.5 & 111.2 & 220.9 & 17.6 & 4.6 & 157.2 \\
\hline A & 27.0 & 15. & 6.4 & 30.0 & 14.8 & 4.1 & 1.9 & 28.9 & 31.6 & 15.2 & 3.1 & 2.1 \\
\hline A & 30.0 & 15.6 & 6.1 & 31.7 & 14.9 & 5.3 & 2.1 & 32.6 & 35.4 & 15.8 & 3.1 & 2.3 \\
\hline A & 28.4 & 15.4 & 6.2 & 37.0 & 15.2 & 4.1 & 5.8 & 36.6 & 47.9 & 15.6 & 3.5 & 7.3 \\
\hline A & 27.5 & 14.8 & 6.0 & 36.7 & 15.1 & 3.8 & 5.5 & 37.0 & 49.3 & 15.4 & 3.0 & 7.4 \\
\hline A & 29.7 & 14.9 & 6.6 & 48.5 & 15.5 & 3.6 & 10.6 & 46.7 & 73.0 & 16.3 & 2.9 & 16.8 \\
\hline A & 27.9 & 15.5 & 5.9 & 44.2 & 15.0 & 4.0 & 10.2 & 45.8 & 74.0 & 36.2 & 2.9 & 17.1 \\
\hline A & 24.9 & 15 & 6.1 & 59 & 16 & 4.5 & 37.0 & 61.8 & 137.6 & 17.3 & 4.5 & 108.1 \\
\hline A & 28.2 & 15.2 & 6.2 & 56.8 & 16.1 & 4.8 & 39.9 & 56.4 & 131.5 & 17.1 & 4.5 & 108.1 \\
\hline A & 29.1 & 14.4 & 5.6 & 65.5 & 15.7 & 4.4 & 48.3 & 64.8 & 149.9 & 17.1 & 4.6 & 123.8 \\
\hline A & 29.1 & 15.3 & 5.4 & 78.2 & 15.6 & 4.4 & 50.7 & 79.2 & 169.0 & 16.8 & 4.7 & 135.5 \\
\hline B & 32.7 & 15.7 & 3.6 & 36.5 & 15. & 3.5 & 7.1 & 36.2 & 40.6 & 15.3 & 4.5 & 7.9 \\
\hline B & 34.6 & 15.6 & 3.5 & 39.6 & 15.2 & 3.5 & 7.5 & 42.0 & 46.0 & 15.6 & 4.3 & 9.0 \\
\hline B & 33.7 & 16. & 3. & 45 & 15 & 4. & & & 54.2 & 15.8 & 5.6 & 21.3 \\
\hline B & 35.6 & 15.8 & 3.5 & 47.7 & 15.1 & 4.2 & 18.1 & 47.8 & 57.8 & 15.1 & 5.4 & 22.5 \\
\hline B & 32. & 16.1 & 3.4 & 47.9 & 15.2 & 4.8 & 27.0 & 50.7 & 57.9 & 15.5 & 6.3 & 39.2 \\
\hline B & 32.3 & 15.9 & 3.8 & 45.8 & 15.1 & 4.3 & 27.0 & 49.1 & 63.9 & 15.0 & 6.9 & 37.9 \\
\hline B & 31.4 & 16.1 & 3.3 & 48.3 & 15.3 & 4.9 & 49.1 & 47.0 & 52.6 & 15.8 & 5.9 & 72.8 \\
\hline B & 31.5 & 16.0 & 3.4 & 47.5 & 15.1 & 5.6 & 48.7 & 51.2 & 58.4 & 15.3 & 5.9 & 75.7 \\
\hline
\end{tabular}


TABLE 2 (continued)

\begin{tabular}{|c|c|c|c|c|c|c|c|c|c|c|c|c|}
\hline \multirow{3}{*}{$\begin{array}{l}\text { Diet } \\
\text { code }\end{array}$} & \multicolumn{7}{|c|}{ Second period } & \multicolumn{5}{|c|}{ Third period } \\
\hline & \multirow{2}{*}{$\begin{array}{l}\text { Init. } \\
\text { wt. } \\
\text { (g) }\end{array}$} & \multicolumn{2}{|c|}{ Body comp. } & \multirow{2}{*}{$\begin{array}{l}\text { Final } \\
\text { wt. } \\
\text { (g) }\end{array}$} & \multicolumn{2}{|c|}{ Body comp. } & \multirow{2}{*}{$\begin{array}{l}\text { Feed } \\
\text { (g/ } \\
21 \text { day) }\end{array}$} & \multirow{2}{*}{$\begin{array}{l}\text { Init. } \\
\text { wt. } \\
\text { (g) }\end{array}$} & \multirow{2}{*}{$\begin{array}{l}\text { Final } \\
\text { wt. } \\
\text { (g) }\end{array}$} & \multicolumn{2}{|c|}{ Body comp. } & \multirow{2}{*}{$\begin{array}{l}\text { Feed } \\
\text { (g/ } \\
21 \text { day) }\end{array}$} \\
\hline & & $\begin{array}{l}\text { prot. } \\
(\%)\end{array}$ & $\begin{array}{l}\text { fat } \\
(\%)\end{array}$ & & $\begin{array}{l}\text { prot. } \\
(\%)\end{array}$ & $\begin{array}{l}\text { fat } \\
(\%)\end{array}$ & & & & $\begin{array}{l}\text { prot. } \\
(\%)\end{array}$ & $\begin{array}{l}\text { fat } \\
(\%)\end{array}$ & \\
\hline $\mathbf{B}$ & 32.1 & 16.2 & 3.7 & 51.1 & 15.1 & 4.6 & 57.0 & 50.9 & 59.2 & 15.0 & 5.9 & 90.5 \\
\hline $\mathbf{B}$ & 34.1 & 15.8 & 3.2 & 49.6 & 15.1 & 5.3 & 59.0 & 50.2 & 58.4 & 15.6 & 6.3 & 85.9 \\
\hline $\mathbf{B}$ & 26.7 & 14.9 & 5.6 & 29.2 & 14.4 & 5.4 & 5.9 & 29.7 & 34.0 & 14.7 & 6.2 & 9.8 \\
\hline B & 26.2 & 15.3 & 5.9 & 28.4 & 15.1 & 5.6 & 5.8 & 28.4 & 33.2 & 14.6 & 6.2 & 6.3 \\
\hline $\mathbf{B}$ & 26.9 & 14.9 & 6.7 & 28.6 & 15.0 & 5.8 & 13.6 & 27.8 & 31.3 & 15.1 & 6.6 & 13.9 \\
\hline B & 26.7 & 14.9 & 5.7 & 30.5 & 15.1 & 6.8 & 13.8 & 33.2 & 39.7 & 14.9 & 7.2 & 16.0 \\
\hline $\mathbf{B}$ & 25.9 & 15.3 & 6.4 & 32.5 & 14.4 & 6.3 & 22.0 & 31.9 & $\mathbf{3 4 . 0}$ & 15.4 & 6.9 & 25.8 \\
\hline B & 27.7 & 15.6 & 6.1 & 34.6 & 14.7 & 7.3 & 23.9 & 34.0 & 40.6 & 15.1 & 7.8 & 27.2 \\
\hline $\mathbf{B}$ & 27.7 & 14.6 & 6.3 & 35.0 & 13.9 & 6.2 & 46.5 & 36.6 & 39.4 & 15.1 & 6.7 & 59.7 \\
\hline $\mathbf{B}$ & 25.5 & 14.9 & 6.0 & 32.2 & 15.1 & 6.4 & 45.1 & 34.3 & 44.0 & 15.2 & 7.3 & 56.3 \\
\hline $\mathbf{B}$ & 28.3 & 15.3 & 5.8 & 35.3 & 15.4 & 7.6 & 54.3 & 34.1 & 39.0 & 15.1 & 6.7 & 62.9 \\
\hline $\mathbf{B}$ & 25.6 & 15.4 & 6.0 & 31.8 & 15.4 & 7.4 & 51.0 & 32.2 & 38.9 & 15.3 & 6.6 & 58.8 \\
\hline
\end{tabular}

\section{TABLE 3}

Analysis of variance (mean squares) for replicates, initial body composition, feed composition, interaction of initial body composition and feed composition and the regression on feed ration ( $\mathrm{g} / \mathrm{fish}$ per 21 days). The analysis is presented for fresh weight gain ( $\mathrm{g} / \mathrm{fish}$ per 21 days), protein gain (g/fish per 21 days) and fat gain ( $\mathrm{g} /$ fish per 21 days). The remainders after the regression on feed ration within each combination of initial body composition and diet composition are added to the total remainder because they were never significant

\begin{tabular}{|c|c|c|c|c|c|c|c|}
\hline \multirow{2}{*}{$\begin{array}{l}\text { Source } \\
\text { of } \\
\text { variation }\end{array}$} & \multirow[t]{2}{*}{ d.f. } & \multicolumn{3}{|c|}{ Second period } & \multicolumn{3}{|c|}{ Third period } \\
\hline & & $\begin{array}{l}\text { Fresh } \\
\text { weight } \\
\text { gain }\end{array}$ & $\begin{array}{l}\text { Protein } \\
\text { gain }\end{array}$ & $\begin{array}{l}\text { Fat } \\
\text { gain }\end{array}$ & $\begin{array}{l}\text { Fresh } \\
\text { weight } \\
\text { gain }\end{array}$ & $\begin{array}{l}\text { Protein } \\
\text { gain }\end{array}$ & $\begin{array}{l}\text { Fat } \\
\text { gain }\end{array}$ \\
\hline Replicate & 1 & 17.64 & 0.56 & 0.08 & 4.46 & 0.07 & 0.20 \\
\hline \multicolumn{8}{|l|}{ Initial } \\
\hline body comp. & 1 & $1320.20^{* *}$ & $26.07^{* *}$ & $3.40^{* *}$ & $1061.00^{* *}$ & $35.64 * *$ & $6.26^{* *}$ \\
\hline $\begin{array}{l}\text { Feed comp. } \\
\text { Interaction }\end{array}$ & 1 & $3695.24^{* * *}$ & $103.97^{* *}$ & 0.02 & $18842.11^{* *}$ & $627.90^{* *}$ & $16.51^{* *}$ \\
\hline (body $\times$ feed) comp. & 1 & $135.35^{*}$ & $3.58^{* *}$ & 0.09 & $585.30^{* *}$ & $20.16^{* *}$ & 0.55 \\
\hline Feed ration & 8 & $1632.29^{* *}$ & $42.38^{* *}$ & $3.80^{* *}$ & $5369.94^{* *}$ & $178.82^{* *}$ & $16.57^{* *}$ \\
\hline Remainder & 27 & 20.60 & 0.26 & 0.07 & 43.69 & 1.16 & 0.24 \\
\hline
\end{tabular}

$P<0.05$.

$* P<0.01$. 

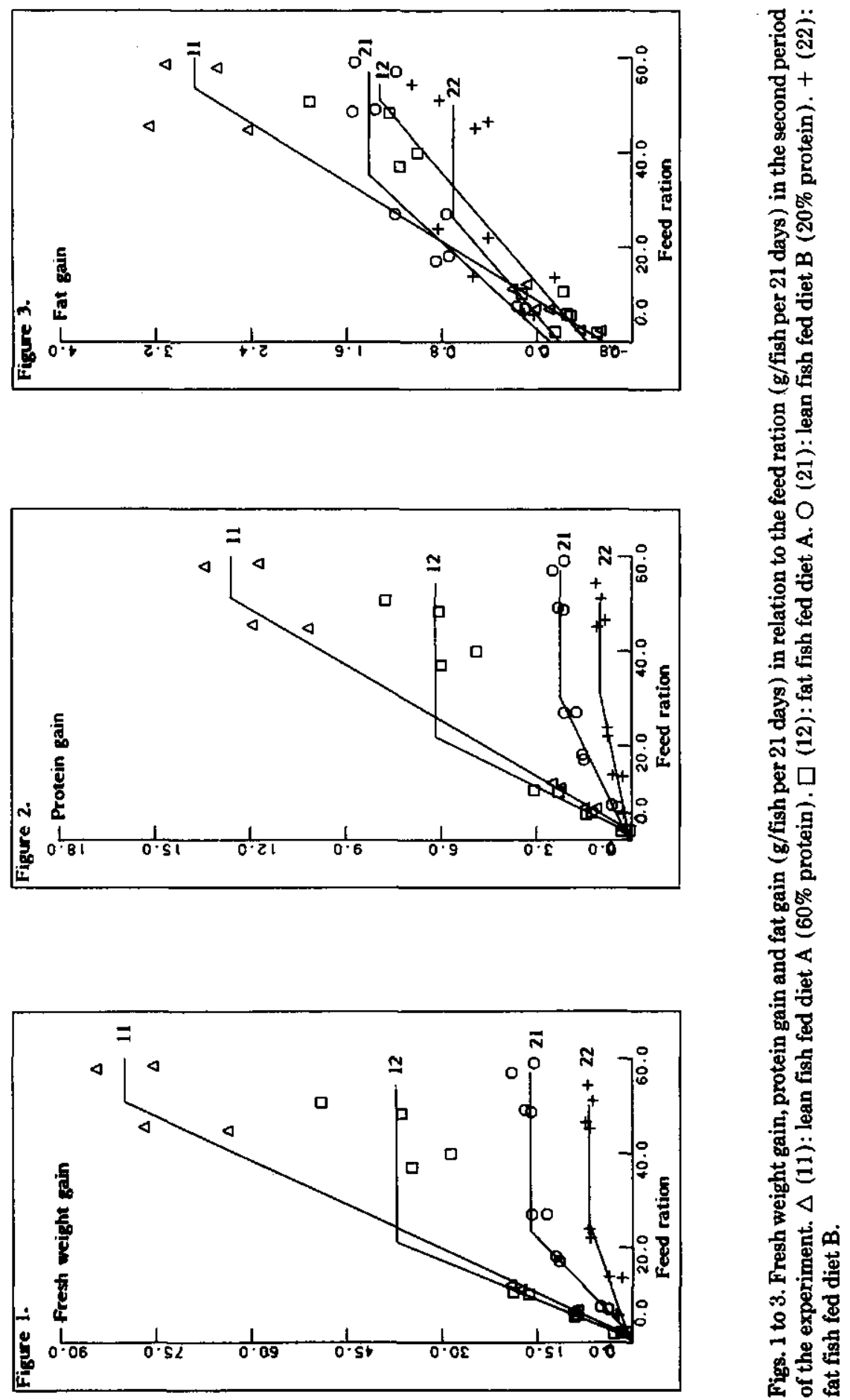
TABLE 4

Intercepts ( $\mathrm{g} /$ fish per 21 days), regression coefficients $(-)$, correlation coefficients $(-)$, satiation feeding and maximum gain ( $\mathrm{g} /$ fish per 21 days) found in the regression equation of feed ration on fresh weight gain, protein gain and fat gain ( $\mathrm{g} /$ fish per 21 days)

\begin{tabular}{|c|c|c|c|c|c|c|c|}
\hline & \multirow[t]{2}{*}{ Code } & \multicolumn{3}{|c|}{ Second period } & \multicolumn{3}{|c|}{ Third period } \\
\hline & & $\begin{array}{l}\text { Fresh } \\
\text { weight } \\
\text { gain }\end{array}$ & $\begin{array}{l}\text { Protein } \\
\text { gain }\end{array}$ & $\begin{array}{l}\text { Fat } \\
\text { gain }\end{array}$ & $\begin{array}{l}\text { Fresh } \\
\text { weight } \\
\text { gain }\end{array}$ & $\begin{array}{l}\text { Protein } \\
\text { gain }\end{array}$ & $\begin{array}{l}\text { Fat } \\
\text { gain }\end{array}$ \\
\hline \multirow[t]{4}{*}{ Intercept } & 11 & -1.79 & -0.46 & -0.56 & -1.93 & -0.60 & -0.36 \\
\hline & 12 & -1.35 & -0.40 & -0.42 & -0.72 & -0.08 & -0.39 \\
\hline & 21 & -0.88 & 0.09 & -0.11 & 3.29 & 0.64 & 0.22 \\
\hline & 22 & 0.26 & 0.06 & -0.19 & 4.64 & 0.51 & 0.49 \\
\hline \multicolumn{8}{|l|}{ Regres- } \\
\hline sion & 11 & 1.61 & 0.25 & 0.06 & 1.57 & 0.30 & 0.04 \\
\hline \multirow[t]{3}{*}{ coeff. } & 12 & 1.82 & 0.30 & 0.03 & 1.66 & 0.29 & 0.05 \\
\hline & 21 & 0.72 & 0.07 & 0.04 & 0.21 & 0.03 & 0.04 \\
\hline & 22 & 0.26 & 0.03 & 0.03 & 0.001 & 0.02 & 0.002 \\
\hline \multicolumn{8}{|l|}{ Corre- } \\
\hline lation & 11 & 0.99 & 0.99 & 0.99 & 0.98 & 0.99 & 0.98 \\
\hline \multirow[t]{3}{*}{ coeff. } & 12 & 0.95 & 0.96 & 0.95 & 0.99 & 0.99 & 0.98 \\
\hline & 21 & 0.96 & 0.87 & 0.94 & 0.71 & 0.73 & 0.81 \\
\hline & 22 & 0.93 & 0.94 & 0.75 & 0.32 & 0.51 & 0.18 \\
\hline \multicolumn{8}{|l|}{ Satia- } \\
\hline tion & 11 & 50.88 & 51.30 & 53.59 & 82.01 & 79.60 & 174.90 \\
\hline \multirow[t]{3}{*}{ feeding } & 12 & 21.20 & 21.86 & 51.18 & 49.51 & 50.58 & 86.70 \\
\hline & 21 & 23.60 & 30.28 & 35.35 & 18.83 & 20.32 & 17.44 \\
\hline & 22 & 25.20 & 31.37 & 26.18 & - & 32.00 & - \\
\hline \multicolumn{8}{|l|}{ Maximum } \\
\hline \multirow[t]{4}{*}{ gain } & 11 & 79.93 & 12.62 & 2.87 & 126.83 & 23.12 & 7.16 \\
\hline & 12 & 37.22 & 6.18 & 1.32 & 81.46 & 14.64 & 3.77 \\
\hline & 21 & 16.13 & 2.27 & 1.41 & 7.32 & 1.27 & 0.90 \\
\hline & 22 & 6.83 & 1.00 & 0.70 & 6.04 & 0.99 & 0.42 \\
\hline
\end{tabular}

11: $\operatorname{diet} A$ (60\% protein) , lean fish.

12: $\operatorname{diet} A(60 \%$ protein $)$, fat fish.

21: diet B (20\% protein), lean fish.

22: diet B (20\% protein), fat fish.

remarkable differences in maximum gain as a consequence of initial body composition and diet composition are illustrated in Figs. 1, 2 and 3 and in Table 4.

\section{Simulation}

\section{The model}

Simulation was performed using the model presented in detail in the first two papers of this series (Machiels and Henken, 1986, 1987). In the first paper growth is simulated for different ration sized of a fixed feed composition. The model was extended in the second paper to include different feed compositions. Starting from the feed intake, digestion, biosynthesis and metabolic losses are calculated in the model. 
It is assumed that at a fixed feed composition the maximum consumption is regulated by homeostatic growth (Machiels and Henken, 1986). The model describes maximum attainable growth as a function of body weight and temperature, and if calculated growth equals the maximum attainable growth, maximum consumption is reached. This assumption, however, is incorrect if the feed composition varies (Machiels and Henken, 1987). The maximum attainable growth varies with the feed composition. Therefore, a direct relation between a standard maximum consumption and fish weight and temperature is used, because the variation in consumption providing maximum gain is less than the variation for maximum gain itself.

Although feed intake by the fish was not monitored, visual observation in experiments indicated that lean fish were able to consume more feed than fat fish of the same weight. In the model this is effectuated by multiplying the standard maximum composition by a factor which depends on the fat content of the biomass, being 1 for fat contents below $7 \%$ and decreasing linearly to 0 for fat contents increasing from $7 \%$ to $12 \%$ (Machiels and Henken, 1987). This approach resembles the lipostatic theory of Kennedy (1953) for control of feed intake in warm-blooded animals.

\section{Parameterization}

Initial mean fresh body weight and fat content of the fish in the experiments described were used as starting points for the simulation. Feed ration, feed composition and water temperature chosen were similar to the experimental conditions. Simulation was first performed under the assumption that the maximum feed intake is regulated only by body weight and temperature.

Simulation results for those feeding levels at which it was observed that all feed administered was consumed (levels 1 to 3 of diet $A$ and 1 or 1 and 2 of diet $B$ with fat or initially lean fish) corresponded well with the experimental outcome, indicating that the model successfully simulates growth over a wide range of feed compositions. At higher feeding levels of diet A, however, simulated fresh body weight gain, protein gain and fat gain were underestimated for lean fish and overestimated for fat fish. In the case of diet B, simulation results were higher than experimental results for fat fish.

If the above-mentioned factor for the lipostatic control of feed intake was included in the model, there were still large differences between simulation and experimental results. This factor, however, was obtained from an experiment using diets with only $10 \%$ carbohydrate, in which the fish reached a maximum fat content of $12 \%$.

The results of the experiment described here indicate that consumption decreased to zero when fat contents of just $7-8 \%$ were reached, as observẹd in the case of the carbohydrate-rich diet B. On the basis of this observation it is concluded that the lipostatic theory insufficiently explains the long-term regulation of feed intake. 
Apart from the lipostatic theory, another possible explanation for the longterm regulation of feed intake is the glucostatic theory (Scharrer and Geary, 1977), which relates the blood glucose concentration to the feed intake in nonruminant animals. Since glycogen synthesis by $C$. gariepinus is negligible (Yanni, 1961), it may be expected that $C$. gariepinus uses both excess glucose and fatty acids for fat synthesis. It is therefore assumed that both regulatory mechanisms are effective, the lipostatic control at low carbohydrate levels in the blood and the glucostatic at high carbohydrate levels. In the model this assumption is programmed by including a multiplication factor for the standard maximum feed consumption, to find the adjusted maximum value. In Fig. 4 this factor is related to the body fat content of the fish at two carbohydrate levels in the diet. At other dietary carbohydrate levels the factor is found by linear interpolation between the curves. If the factor is found to be negative it is set to zero. If diets differed between the different periods, this multiplication factor will change in time due to the different carbohydrate contents. This change is suppose to be linear with time from the onset of the simulation to the end of the second period.

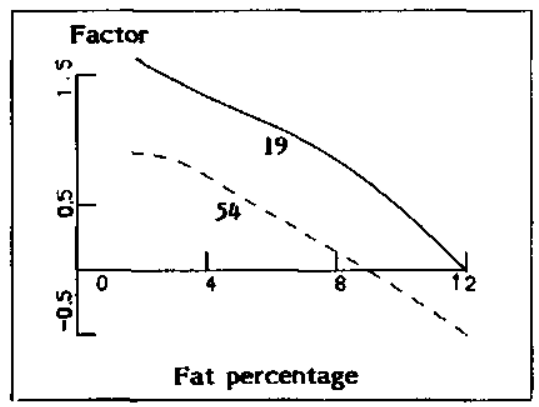

Fig. 4. Relationship between the factor for maximum consumption ( - ) and the fat content (\%) of $C$. gariepinus at two carbohydrate levels ( 19 and $54 \%$ ) in the diet.

The results of the model calculations are presented in Figs. 5, 6 and 7 for simulated $(x)$ and observed $(y)$ fresh weight gain, protein gain and fat gain in the second experimental period. The bisectors represent perfect agreement. The coefficients of variation $\left[\left(\sqrt{\left.\sum(y-x)^{2} /(n-2)\right)} / \bar{y}\right]\right.$ are $0.23,0.25$ and 0.67 for fresh weight gain, protein gain and fat gain, respectively.

\section{Testing}

To test the validity of the adapted model, simulated output should be compared with experiments not used during the modelling procedure. Such independently obtained results of similar experiments are not available. Therefore the model was tested using data from the third and the first period of the same experiment, the data for the parameterization being obtained from the second period. 


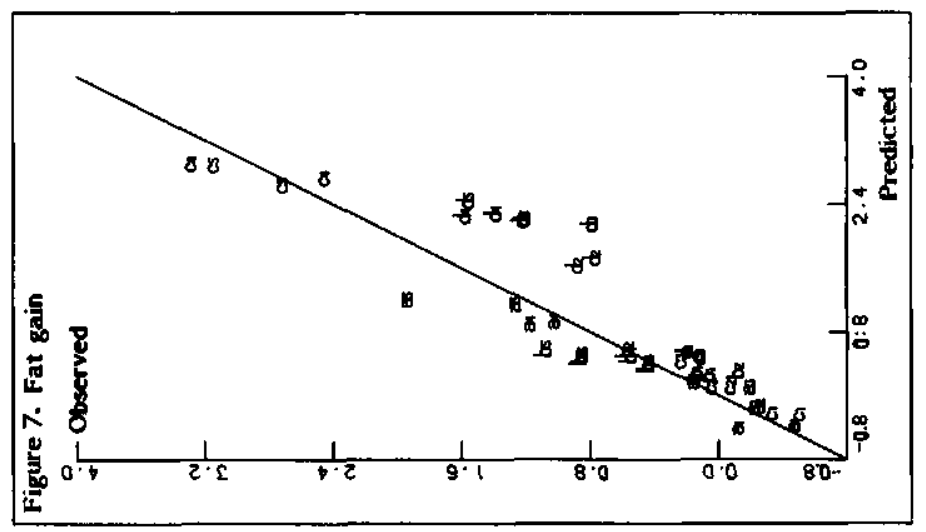

$\exists \infty$

蕇

氛总

을

虽

苜

워

.

.5 .

总

용

毗魚

军

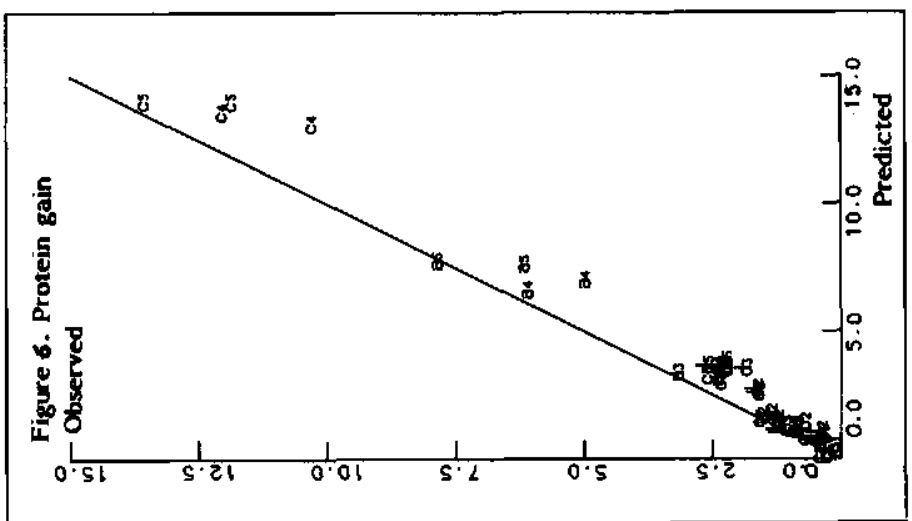

密

倇

몰

密 용류

承

范焉

要

胥

虫

密点

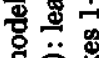

兽苛产

营荳

星

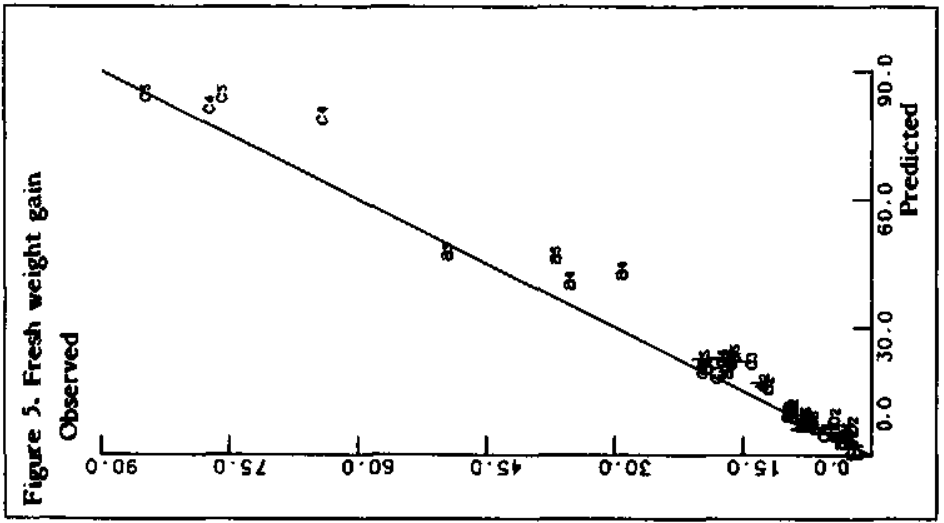

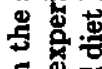

옹

范然透

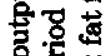

总灾

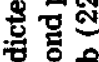

政

ㄷ. $8 . \pm 0$

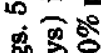
虹罯 


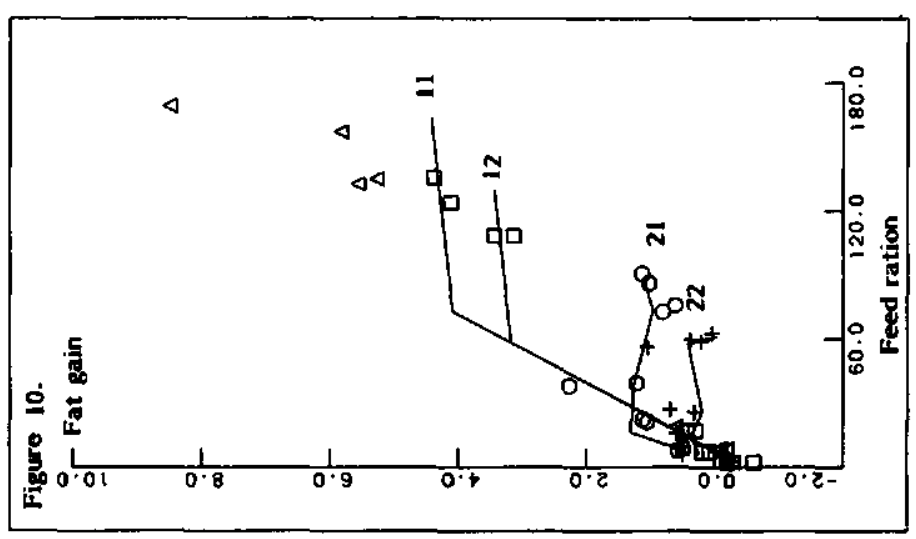

훙

穿

동

出

惫
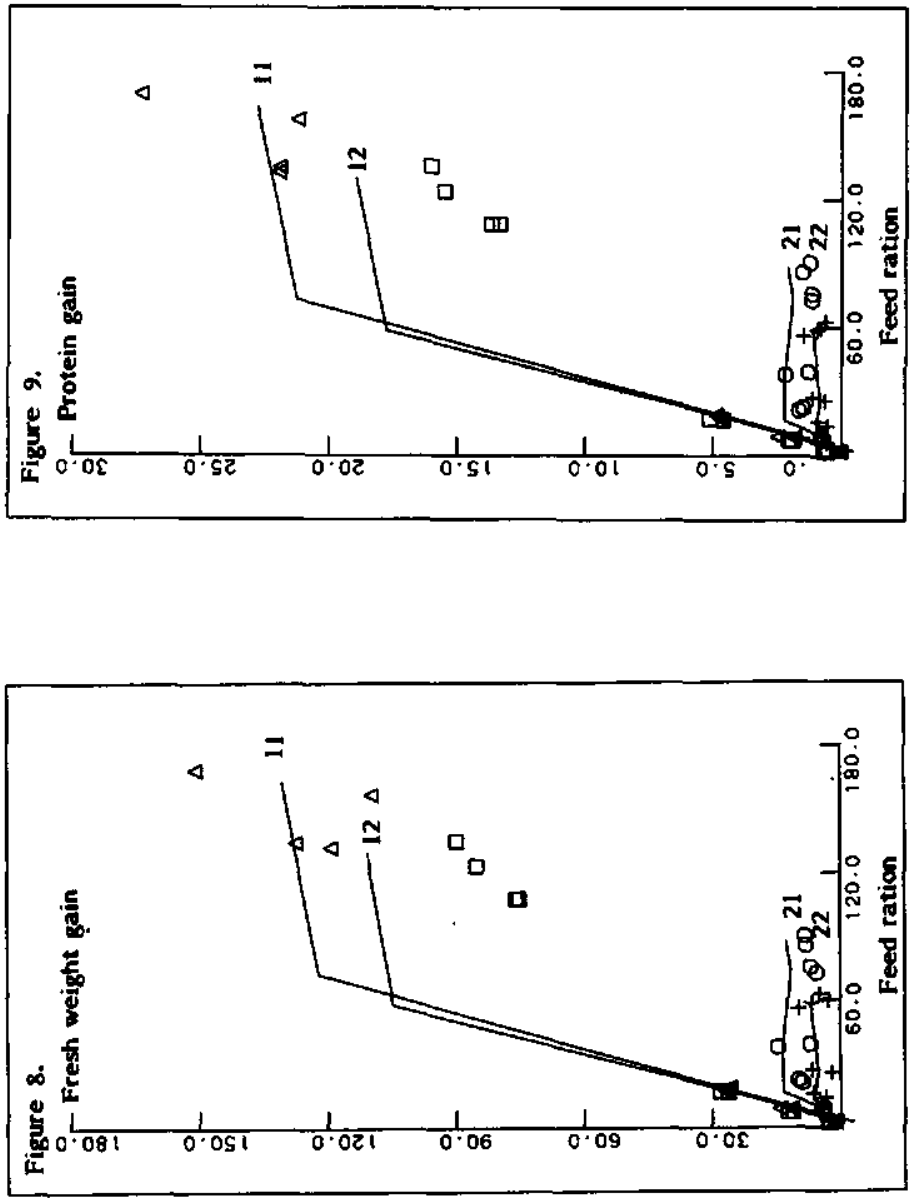

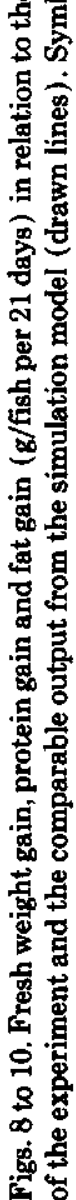


The experimental results found in the third period are similar to the results in the second period. The effect of the initial composition is less pronounced in the third period. Compared with the results found in the second period, the satiation feed ration and the maximum gain are higher for $\operatorname{diet} A$.

The experimental as well as the simulation results for the third period are presented in relation to the feed ration in Figs. 8, 9 and 10 for fresh weight gain, protein gain and fat gain, respectively. Coefficients of variation are 0.34 for fresh weight gain, 0.28 for protein gain and 0.56 for fat gain. Simulated output of fresh weight gain and protein gain shows good agreement with the experimental results for all feeding levels of diet A or B fed to initially lean fish. For the remaining comparisons the simulation at high feeding levels leads to an overestimation. This occurs at feeding levels 4 and 5 of diet $A$ and at levels 2 to 5 of diet B. For protein gain the results were similar. For fat gain the experimental results of the two highest feeding levels of diet A, fed to initially lean fish, were underestimated.

A second verification of the model was done by simulating results of fresh weight gain obtained in the second half of the preliminary period, assuming that the fish were adapted after the first 2 weeks. Fresh weight gain was $7.4 \pm 1.6$ $\mathrm{g} /$ fish per 14 days and $3.2 \pm 1.0 \mathrm{~g} /$ fish per 14 days for diets $A$ and diet $B$, respectively. The results of the model calculations with the same initial values and input variables were $8.6 \pm 0.5 \mathrm{~g} / \mathrm{fish}$ per 14 days and $4.9 \pm 0.4 \mathrm{~g} / \mathrm{fish}$ per 14 days for fish diets $A$ and $B$, respectively. According to the calculation, the feeding levels for $\operatorname{diet} A$ were below satiation and those for $\operatorname{diet} B$ were above satiation in this period.

\section{DISCUSSION AND CONCLUSION}

From the comparison between simulated and experimental results in the first and the third period it is concluded that the model gives good results for feeding levels providing sub-maximum gain. At higher feeding levels there is a difference between model output and experimental results, especially in the case of diet A. After the second experimental period the difference in fat content between initially fat and lean fish was only $0.7 \%$, but the maximum weight gains of these two groups differed by $45 \mathrm{~g}$ in the experiments whereas in the simulation the difference was only $15 \mathrm{~g}$. It is therefore likely that other factors besides those incorporated in the model play a role in the regulation of feed intake. It may also be possible that adaptation to a change of diet is quicker for a change from diet $A$ to diet $B$ than in the opposite case.

Below the maximum weight gain the model is explanatory, but at the maximum weight gain the model has a descriptive character. Since an allometric relation between energy consumption and body weight is used for the fasting metabolic rate at a constant temperature (Machiels and Henken, 1986), the model is also descriptive at the point of starvation. 
Under practical culture conditions fish are mostly fed at or near satiation level. Further enlargement of the explanatory part of the model should concentrate on this satiation feeding level. This requires that the absolute maximum gain of $C$. gariepinus be determined by quantifying the regulation of the feed intake at the explanatory level. Studies on the stomach content and voluntary feed intake can contribute to this (Colgan, 1973).

Both the statistical analyses of the experimental results and the correspondence between model calculations and experimental results indicate a rather simple growth-feed ration relationship for $C$. gariepinus. At low feeding levels a linear relation is found between amount of consumed food and gain. Weight gain and protein gain are higher for fish with a higher fat content. Metabolic expenditures caused by feed intake, assimilation and biosynthesis of fish biomass increase proportionally with the amount of feed consumed. A lean fish will use more protein and less fat for respiration compared with a fat fish of the same weight (Machiels and Henken, 1986).

With increasing ration size the growth-feed ration line flexes downwards rather sharply, reaching a plateau of maximum weight gain. The inflexion point shows the optimum feed ration in the growth-ration curve, which may range from a relatively low to a relatively high ration according to species (Brett and Groves, 1979). For $C$. gariepinus the optimum feed ration and the minimum feed ration providing maximum growth almost coincide. The experimental results show that within one feed composition this maximum weight gain is influenced by the body composition.

This is an important effect of the body composition on growth. Although the efficiency of the conversion from feed protein into fish protein is reduced, when the fish becomes leaner, by an increasing gluconeogenesis from amino acids, the maximum growth increases because the lean fish are capable of consuming more feed. This is favorable for production because the growing period to marketable size is reduced.

Replacement of feed protein by carbohydrates or fat initially increases the protein conversion efficiency, but ultimately consumption will decrease as the fish become fatter, and this consequently will lead to a decrease of the maximum gain. This effect seems to be more pronounced for an increase of carbohydrates than for an increase of the fat content in the diet.

The prime reason for the inability of fish to metabolize glucose rapidly appears to be the low hexokinase activity in different organs (Cowey and Sargent, 1979). If this activity can be raised, for instance through selection, the fish will be able to eat more of a carbohydrate-rich diet. Most waste products, unsuitable for direct human consumption, contain notable quantities of carbohydrates; the capability of $C$. gariepinus to convert such waste is probably small.

Economic factors determine which feed is given in what quantity to produce fish of a required weight. The simulation model can be used to quantify the 


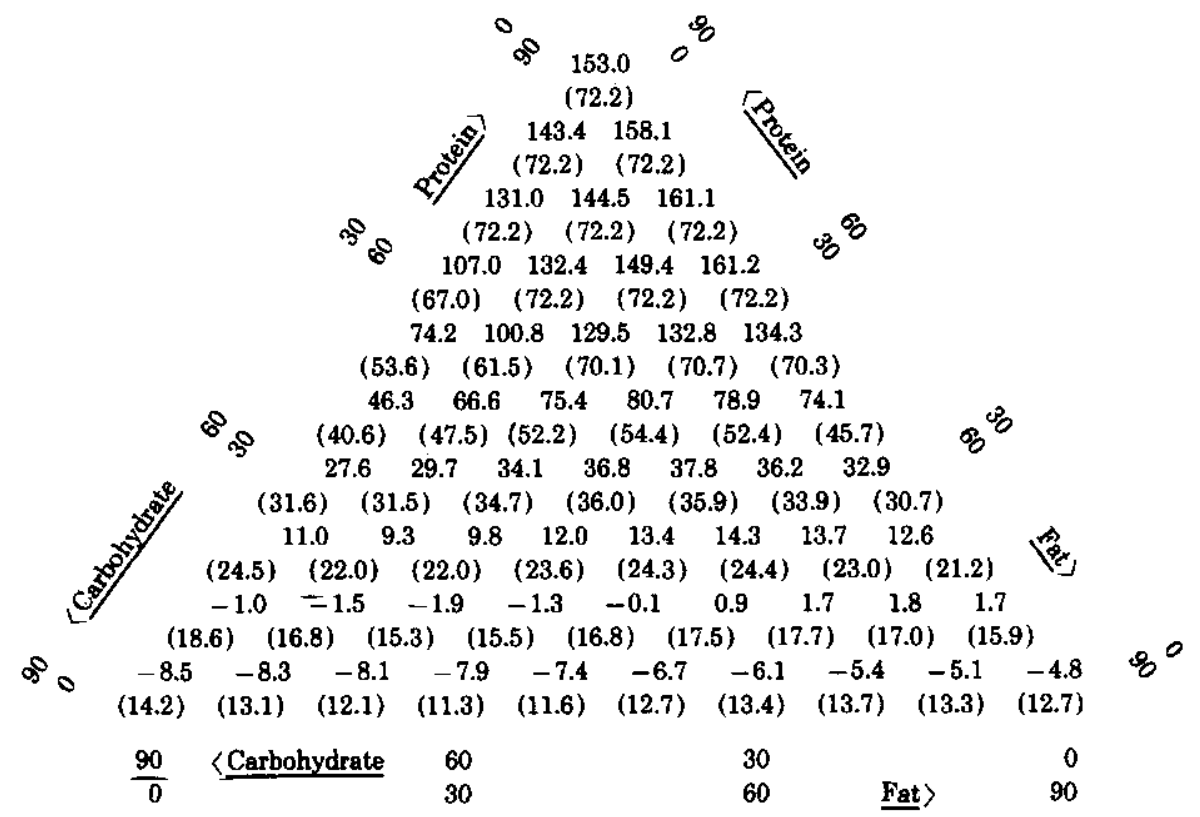

Fig. 11. Predicted fresh weight gain (g/fish per 28 days) of C. gariepinus at $25^{\circ} \mathrm{C}$ fed diets with different protein, fat and carbohydrate fractions (\%). Maximum ration is $2 \%$ of the fresh body weight per day. The actual consumption ( $\mathrm{g} / \mathrm{fish}$ per 28 days) is shown between brackets.

effects of alternative production methods and so contribute to the determination of the economic optimum. As an example, Fig. 11 shows the effect of different feed compositions on fresh weight gain of $C$. gariepinus. The corresponding amounts of feed consumed can be found in the same figure. It can be seen that the highest weight gains will be found when the protein content in the feed is more than $60 \%$ and the fat content from 10 to $30 \%$. At high protein contents problems can occur due to high levels of $\mathrm{NH}_{3}$ in the water, originating from catabolized protein. These limits were not taken into account in the calculations.

\section{REFERENCES}

Brett, J.R. and Groves, T.D.D., 1979. Physiological energetics. In: W.S. Hoar, D.J. Randall and J.R. Brett (Editors), Fish Physiology, Vol. VIII. Bioenergetics and Growth. Academic Press, New York, pp. 280-352.

Colgan, P., 1973. Motivational analysis of fish feeding Behaviour, 45: 38-66.

Cowey, C.B. and Sargent, J.R., 1979. Nutrition. In: W.S. Hoar, D.J. Randall and J.R. Brett (Editors), Fish Physiology, Vol. VIII. Bioenergetics and Growth. Academic Press, New York, pp. $1-70$. 
Hogendoorn, H., 1979. Controlled propagation of the African catfish, Clarias lazera (C. \& V.). I. Reproductive biology and field experiments. Aquaculture, 17: 323-333.

Hogendoorn, H., 1980. Controlled propagation of the African catfish, Clarias lazera (C. \& V.). III. Feeding and growth of fry. Aquaculture, 21: 233-241.

Hogendoorn, H. and Vismans, M.M., 1980. Controlled propagation of the African catfish, Clarias lazera (C. \& V.). II. Artificial reproduction. Aquaculture, 21: 39-35.

Hogendoorn, H., Jansen, J.A.J., Koops, W.J., Machiels, M.A.M., Van Ewijk, P.H. and Van Hees, J.P., 1983. Growth and production of the African catfish Clarias lazera (C. \& V.). II. Effects of body weight, temperature and feeding level in intensive tank culture. Aquaculture, 34: 265-285.

Kennedy, G.C., 1953. The role of depot fat in the hypothalamic control of food intake in the rat. Proc. R. Soc. London, B140: 578-592.

Machiels, M.A.M. and Henken, A.M., 1986. A dynamic simulation model for growth of the African catfish, Clarias gariepinus (Burchell 1822). I. Effect of feeding level on growth and energy metabolism. Aquaculture, 56: 29-52.

Machiels, M.A.M. and Henken, A.M., 1987. A dynamic simulation model for growth of the African catfish, Clarias gariepinus (Burchell 1822). II. Effect of feed composition on growth and energy metabolism. Aquaculture, 60: 33-53.

Scharrer, E. and Geary, N., 1977. Regulation der Futteraufname bei Monogastriden. Ubers. Tiernahr., 5: 103-121.

Yanni, M., 1961. Studies on carbohydrate content of the tissues of Clarias lazera. Z. Vergl. Physiol., 45: 56-60. 
A dynamic simulation model for growth

of the African catfish, Clarias gariepinus (Burchell 1822)

IV. The effect of feed formulation on growth and feed utilization

M.A.M. Machiels

Department of Fish Culture and Fisheries, Agricultural University, P. 0. Box 338, Wageningen (The Netherlands)

Accepted for publication in Aquaculture 
ABSTRACT

Machiels, M.A.M., 1987. A dynamic simulation model for growth of the African catfish, Clarias gariepinus (Burchell 1822). IV. The effect of feed formulation on growth and feed utilization.

A dynamic simulation model is used to calculate the growth of Clarias gariepinus (Burchell) fed with differently formulated diet. To verify the calculations, the results of the simulation are compared with experimental data. The experiments were carried out to determine the growth performance of $C$. gariepinus, fed with diets, containing different protein sources. A fish meal diet was fed at 4 feeding levels in a respiration experiment. The alternative sources (blood meal, casein, groundnut, cottonseed, rapeseed and soybean) were tested at various inclusion rates with fish meal in aquarium experiments at 1 feeding level. In total 33 semi-moist diets were tested.

The output of the simulation model, being fresh weight gain, protein gain, fat gain, oxygen consumption and ammonia production agreed well with results of the respiration experiment, except for fat gain at the highest feeding levels and ammonia production in the second experimental period. It was shown that $C$. gariepinus is able to convert feed nutrients very efficiently into fish biomass. A protein conversion efficiency of nearly $60 \%$ was found.

In the aquarium experiments the fresh weight gain decreased when an increasing part of the fish meal was replaced by alternative protein sources. The output of the simulation model (fresh weight gain) in comparison with the experimental results shows that it is possible to calculate the weight conversions of differently formulated diets. A good alternative for fish meal as a basic component of the protein in the diet is soybean.

\section{INTROOUCTION}

The intensification of fish culture methods, requires the development of complete diets for Clarias gariepinus (Burchell 1822). Complete diets in intensive fish culture are used for the provision of all essential nutrients to the fish. In order to develop such diets it is 
not only necessary to know the specific nutrient requirements of the animal, but also to optimize feed formulation in order to obtain fast growth of high quality fish at low costs (Moore, 1985).

Effects of feed composition on feed utilization and growth of $\underline{C}$. gariepinus were investigated with respect to macro nutrients, protein, fat and carbohydrates (Machiels and Henken, 1985; Henken et al. 1986; Machiels and van Dam, 1987). Results of these experiments were used to calibrate and validate an explanatory model, which was developed to simulate growth and growth composition of C. gariepinus for different feeding levels and feed compositions (Machiels and Henken, 1986; Machiels and Henken, 1987).

Fish diets require a high protein content compared with diets for homeotherms. Traditionally the feed is composed to a large extent of fish meal, which has a protein content of 60-70\%, and a high biological value. There is a growing demand for alternative protein sources, because fish meal is both expensive and difficult to obtain in many areas. For economical and practical reasons, the protein in diets used in fish culture should be derived from locally available and "payable" protein sources.

The suitability of a feedstuff, like a protein source in fish diets, depends on its protein content and the amino acid composition. The protein content should be high enough to formulate the minimum required dietary protein level in a complete diet. The amino acid composition of the protein source determines the conversion efficiency. The part of the protein, which is used for biosynthesis of fish protein depends upon the diet composition, i.e. the protein to fat ratio (Machiels and Henken, 1987). Research on the amino acid requirements of C. gariepinus is lacking, but is should be possible to calculate the weight conversions of various protein sources to fish protein from the intermediate metabolic processes. The relation between diet quality, diet quantity and fish growth can be calculated from these conversion. In this way feed formulation can be related to production parameters.

To verify this hypothesis, results of the calculations were compared with independent experimental data. Several experiments were carried out to determine the growth performance of $\underline{C}$. gariepinus fed with different protein sources of plant and animal origin. The experimental results as well as the comparison of the model output with these experimental results will be discussed in this paper. 
MATERIALS AND METHODS

The protein sources used in the experiments were fish meal, blood meal, casein, groundnut, cottonseed, rapeseed and soybean. Since fish meal was a major ingredient of most diets. this was tested separately in a respiration experiment at 4 feeding levels. The other protein sources were tested at various inclusion rates with fish meal in aquarium experiments at a single feeding level. A $100 \%$ fish meal diet served as a control to allow comparison between different experiments. The diet codes and formulations are presented in table 1.

\section{Simulation}

An explanatory model was developed earlier to simulate growth of C. gariepinus (Machiels and Henken, 1986: Machiels and Henken, 1987): The model was extended in accordance with experimental results from the third publication of this series (Machiels and van Dam, 1987).

The model calculates biosynthesis and other metabolic processes using feed intake and digestion as starting points. Biosynthesis of protein and fat is calculated from general biochemical reaction equations. Weight conversions for the different protein sources were determined according to their amino acid composition as given by Janssen et al., 1979. These biochemical weight conversion reactions are summarized in table 2 .

Under the assumption that both feed- and fish fat consists of tri-oleylglycerol (TOG), the conversion reaction for biosynthesis of body fat is:

$0.96 \mathrm{~g} \mathrm{Olein}+0.10 \mathrm{~g}$ glycerol +0.014 mole ATP $\rightarrow 1 \mathrm{~g} \mathrm{TOG}+0.06 \mathrm{~g} \mathrm{H}_{2} \mathrm{O}$

The amount of glucose obtained from carbohydrate was calculated by multiplying the amount of digestible carbohydrate by 1.11 to account for hydration. The reaction equation for biosynthes is of body fat from glucose is as follows:

$1 \mathrm{~g}$ glucose $+0.22 \mathrm{~g} \mathrm{O}_{2} \longrightarrow 0.29 \mathrm{~g} \mathrm{TOG}+0.63 \mathrm{~g} \mathrm{CO}_{2}+0.30 \mathrm{~g} \mathrm{H}_{2} \mathrm{O}$ 
TABLE 1. Chemical analysis and composition of the experinental diets

Chemical

analysis

diet (in D.M. ) fat dex- OX vit cellu- am/

code prot. fat mix trin min lose acid

(1) $\%$ (2) (3)

$\% \% \% \%$

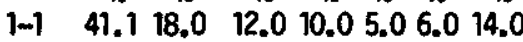

2-1 $39.1 \quad 16.6 \quad 13.6 \quad 10.05 .06 .0 \quad 0$

2-2 $37.9 \quad 17.6 \quad 13.6 \quad 10.0 \quad 5.06 .0 \quad 0$

$\begin{array}{llllllllll}2-3 & 40.1 & 19.1 & 16.0 & 10.0 & 5.0 & 6.0 & 0.8\end{array}$

2-4

$2-5$

$2-6$

$2-7$

$2-8$

$2-9$

2-10

2-11

2-12

3-1

$3-2$

3-3

$3-4$

$3-5$

3-7

$3-8$

$3-9$

$\begin{array}{lllllll}38.3 & 21.3 & 16.0 & 10.0 & 5.0 & 6.0 & 0.8\end{array}$

$40.020 .4 \quad 16.0 \quad 10.0 \quad 5.06 .0 \quad 4.2$

$39.424 .1 \quad 16.0 \quad 30.05 .06 .0 \quad 4.2$

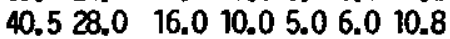

$38.017 .6 \quad 16.010 .0 \quad 5.06 .021 .8$

$38.922 .1 \quad 16.010 .05 .06 .016 .9$

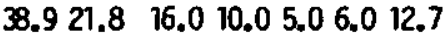

$41.326 .3 \quad 76.0 \quad 10.05 .06 .011 .7$

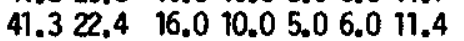

$35.321 .4 \quad 13.6 \quad 9.93 .03 .0 \quad 0$

$36.6 \quad 17.6 \quad 13.8 \quad 10.03 .03 .0 \quad 0$

$\begin{array}{lllllll}40.4 & 15.4 & 10.9 & 9.9 & 3.0 & 3.0 & 8.4\end{array}$

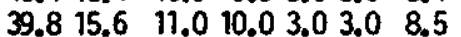

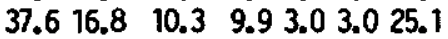

$38.414 .2 \quad 10.4 \quad 10.03 .03 .025 .2$

$\begin{array}{lllllll}39.0 & 15.7 & 10.8 & 9.9 & 3.0 & 3.0 & 0\end{array}$

$\begin{array}{llllllll}38.7 & 16.0 & 11.0 & 10.0 & 3.0 & 3.0 & 0\end{array}$

$\begin{array}{lllllll}39.3 & 16.0 & 10.7 & 9.9 & 3.0 & 3.0 & 11.3\end{array}$

3-10

4-1 39.812 .1

4-2

4-3

4-4

$\begin{array}{llll}4-6 & 37.0 & 15.4\end{array}$

4-7 $36.4 \quad 18: 8$

$4-8$

4-9 33.714 .2

4-10 $34.5 \quad 15.5$
10.910 .03 .03 .011 .5

$8.311 .2 \quad 3.74 .5 \quad 3.3$

$8.311 .23 .74 .5 \quad 3.3$

$8.311 .2 \quad 3.74 .5 \quad 9.5$

$8.311 .2 \quad 3.7 \quad 4.5 \quad 9.5$

8.311 .23 .74 .515 .6

8.311 .33 .74 .515 .6

8.311 .23 .74 .527 .9

11.115 .05 .06 .023 .5

8.311 .23 .74 .535 .3

8.311 .23 .74 .531 .6 supp.

fish

meal altermative

$\begin{array}{cc}\% & \% \\ -\quad 52.0 & 0\end{array}$

$+\quad$

- 0

$+\quad 13.1$

- 13.1

$+\quad 26.1$

- 26.1

$-\quad 52.2$

- 0

- 26.1

- 26.1

- $\quad 39.2$

- $\quad 44.4$

$+\quad 19.8$

- 20.1

20.1
$+\quad 35.9$

- 36.3

48.1
$+\quad 48.4$

- 48.4

$+\quad 23.6$

- 24.0

\begin{tabular}{l}
$+\quad 35.8$ \\
\hline
\end{tabular}

- 36.3

$+\quad 0$

$-\quad 0$

$+\quad 11.1$

- 11.1

$+\quad 22.2$

- 22.2

- 44.4

- 0

- 22.3

- 33.3
65.4 (Groundnut)

65.4 (Groundrut)

49.1 (Groundnut)

49.1 (Groundrut)

32.7 (Groundnut)

32.7 (Groundrut)

0 (Control diet)

41.2 (Casein)

20.6 (Casein)

24.2 (Blood meal)

12.1 (Blood meal)

7.2 (Blood meal)

49.6 (Cottonseed)

50.2 (Cottonseed)

27.9 (Cottonseed)

28.1 (Cottonseed)

0 (Control diet)

0 (Control diet)

48.1 (Rapeseed)

48.9 (Repeseed)

25.0 (Rapeseed)

25.4 (Ropeseed)

69.0 (Soybean)

69.0 (Soybean)

51.7 (Soybean)

51.7 (Soybean)

34.5 (Soybean)

34.5 (Soybean)

0 (Control diet)

39.4 (Casein)

14.8 (Casein)

7.4 (Casein)

(1): The fat inix was based on fish oil.

(2): Carboxyl methyl œllulose.

(3): Vitamin \& mineral mix. Trouw \& Co. Putten, The Netherlands.

(4): -: Ho amino axid supplementation. 
Table 2. Paraneter values for the weight corversion in biosynthesis of fish protein from different protein sources used in the experiments. The hydration of the protein was accounted for by multiplying the anount of feed protein by 1.18

Biosynthesis of fish protein is presented according to the following reaction equation:

$1 \mathrm{~g}$ Amino acid + (a) g $\mathrm{O}_{2}+$ (b) mole ATP $\Longrightarrow$

(c) g protein + (d) g $\omega_{2}+\left(\right.$ e) g glucose + (f) g $\mathrm{H}_{2} \mathrm{O}+$ (g) g N/3

$\mathrm{O}_{2}$ AIP protein $\mathrm{OO}_{2}$ glu- $\mathrm{H}_{2} \mathrm{O} \quad \mathrm{N}_{3}$ diet limiting

(a) (b) (c) (d) $\begin{array}{llll}\text { cose } & \text { (e) (f) (g) }\end{array}$

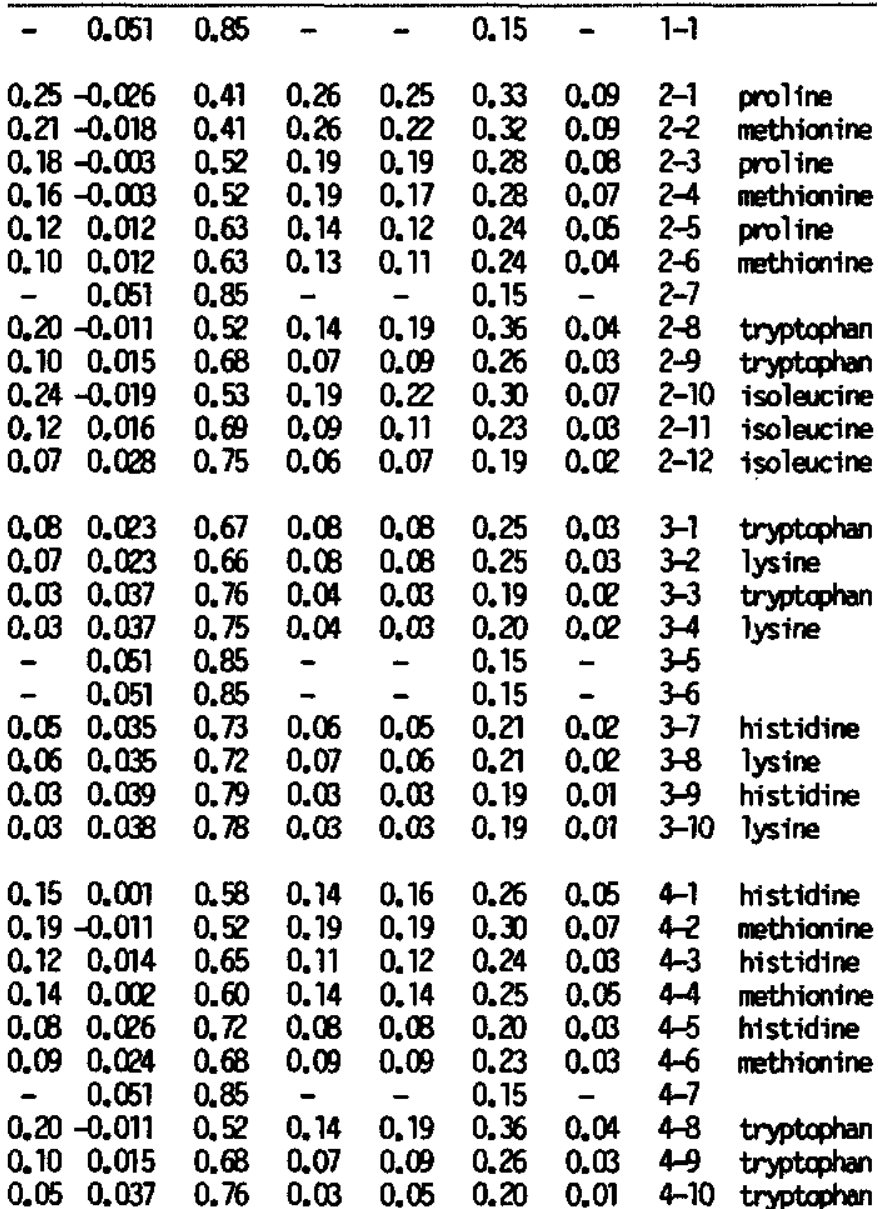


Energy for respiration is formed by breakdown of the body substances protein and fat. The difference between the amounts of protein and fat synthesized and that required for respiration constitute the net protein and fat gain. Fresh weight gain is calculated from the protein gain. The fat gain is thought to affect the body composition (Machiels and Henken, 1986).

At high feed rations fish do not eat all the feed offered. Feed intake regulation in the model is controlled by fish weight, temperature, biomass composition and carbohydrate content of the diet (Machiels and Henken, 1987; Machiels and Van Dam, 1987).

Mean fish weight per tank and the fat content of the fish at the beginning of an experiment were initial values for the model calculations.

\section{Experiments}

Feed and Fish

Commercially available samples of fish meal, casein, blood meal, soybean, groundnut, cottonseed and rapeseed were obtained from various sources. The formulation and proximate analysis of the 33 diets is given in table 1. The crude protein content of the test diets was 38.5 $( \pm 1.9) \%$ of the dry matter. Total dietary protein was supplied by fish meal in the control diets. The test diets contained graded levels of fish meal supplemented with one of the alternative protein sources. Were possible the alternative sources supplied from 0 to $100 \%$ of the total protein in the diets.

Each diet contained 8-10\% fat mix, 3-6\% vitamin/mineral mix (Trouw \& Co, Putten. The Netherlands.), 3-5\% carboxyl methyl cellulose as binder, 10-15\% dextrin and 0-35\% cellulose, depending on the protein content of the protein source. The calculated metabolizable energy (ME) content of the diets was $12.6( \pm 1.2) \mathrm{kJ} / \mathrm{g}$, using ME-values of $16.7 \mathrm{~kJ} / \mathrm{g}$ for protein and dextrin and $37.7 \mathrm{~kJ} / \mathrm{g}$ for fat mix.

The soybean, groundnut, cottonseed and rapeseed diets were formulated in duplicate. One of each pair was supplemented with synthetic amino acids (arginine, lysine, methionine and cysteine) up to the levels recommended for channel catfish (N.R.C. 1977). The amino acid com- 
position of the protein in the diets was calculated from Janssen et al. (1979) and N.R.C. (1977). The content of lysine and methionine in fishmeal can vary to a great extent depending upon the origin of the fishmeal (N.R.C. 1977). Therefore, one control diet in experiment 3 was supplemented with $4.5 \mathrm{~g}$ lysine and $1.5 \mathrm{~g}$ methionine per $\mathrm{kg}$. After mixing, the diets were stored at $4{ }^{\circ} \mathrm{C}$ in air-tight buckets until used. Water was added to the mixtures before feeding, so that the diets were fed in a semi-moist form.

The experimental design, mean initial weight, stocking density, feeding level and water temperature for each of the different experiments is given in table 3 .

Experiment 1 took place in 175 1. balance respirometers (Hogendoorn et al., 1981), while experiment 2,3 and 4 were conducted in 150 ? glass aquariums. Both respirometers and aquariums are part of recirculation systems including sedimentation tanks and biological filters (Hogendoorn et al.. 1983). The experiments in the aquaria were run in duplicate.

C. gariepinus were obtained using the methods described earlier (Hogendoorn, 1979; 1980; Hogendoorn en Vismans, 1980). The fish, full sibs in each experiment, were reared to the required initial weight according to the recommendations (Hogendoorn et al. 1983) and fed with a conmercial trout diet (Trouw \& Co, Putten, The Netherlands).

Experimental procedure

At the beginning of the experiments the fish were hand graded and assigned to the experimental tanks, while a sample was taken for analysis of body composition. The feeding was based on the dry matter content of the diets and the fresh body weight of the fish. The feed ration was adjusted daily, assuming an overall feed conversion (0.91.4), depending on the fish weight and the feeding level (Hogendoorn et a1. 1983). The feed was provided during the night using 'Scharflinger' conveyor belt feeders. Feed intake was not monitored and it is possible that part of the feed was not eaten in some experiments.

After 4 weeks the fish in each tank were sampled for analysis of body composition. In experiment 3 and 4 the remaining fish were weighed and used again in the second experimental period of 4 weeks. 
Table 3. Experimental design of the experiments. Initial weight (g), density (number of fish/tank), feeding level (percentage of fresh body weight/day) and temperature $\left({ }^{\circ} \mathrm{C}\right)$ in two experimental periods of 4 reeks each.

\begin{tabular}{|c|c|c|c|c|c|}
\hline & & & experiment & unber & \\
\hline & & 1 & 2 & 3 & 4 \\
\hline & system & respirameter & aquariun & aquarium & aquarium \\
\hline & temperature & 25 & 25 & 27 & 25 \\
\hline & $\begin{array}{l}\text { protein } \\
\text { source }\end{array}$ & Fish meal & $\begin{array}{l}\text { Blood meal } \\
\text { Casein } \\
\text { Groundnut }\end{array}$ & $\begin{array}{l}\text { Cottonseed } \\
\text { Rapeseed }\end{array}$ & $\begin{array}{l}\text { Soybean } \\
\text { Casein }\end{array}$ \\
\hline 1e Per. & $\begin{array}{l}\text { initial wt. } \\
\text { density } \\
\text { feeding lv. }\end{array}$ & $\begin{array}{l}9.9(+0.4) \\
100 \\
2.0-6.0\end{array}$ & $\begin{array}{l}10.8( \pm 1.1) \\
55 \\
3.5\end{array}$ & $\begin{array}{l}8.6(+0.5) \\
50 \\
6.7\end{array}$ & $\begin{array}{l}133.4(+12.6) \\
30 \\
2.0\end{array}$ \\
\hline Ze Per. & $\begin{array}{l}\text { initial wt. } \\
\text { density } \\
\text { feeding lv. }\end{array}$ & $\begin{array}{l}56.9( \pm 3.9) \\
25 \\
1.3-3.9\end{array}$ & $\begin{array}{l}44.1( \pm 6.6) \\
25 \\
1.5\end{array}$ & $\begin{array}{l}52.5( \pm 4.3) \\
25 \\
4.8\end{array}$ & $\begin{array}{l}205.8(+18.9) \\
20 \\
2.0\end{array}$ \\
\hline
\end{tabular}

In experiment 1 and 2 newly reared fish, weighed and sampled for body composition analysis, were used in the second experimental period.

After the second period all fish in each tank were weighed and taken as sample. The sampled fish were kept at $-18{ }^{\circ} \mathrm{C}$ until analyses of body composition could be performed. Fish samples as well as samples of the diets were analyzed in duplicate for dry matter, crude protein ( $N$ Kjeldahl-6.25) and crude fat (hexane extraction).

On the first day, and once a week thereafter, the oxygen consumption of the fish was measured for a period of $24 \mathrm{~h}$ in experiment 1 . During the $24 \mathrm{~h}$ monitoring period, also the water in the sedimentation funnels of the system was sampled continuously for analysis of ammonia according to NEN (1977).

\section{RESULTS}

The average weight of the fish at the start and at the end of each period, the amount of feed given and the body composition are presented in tables 4, 5, 6 and 7 for experiments 1, 2, 3 and 4 respectively. 
Table 4. Results of experiment 1. Initial and tenminal body weight, chemical composition of the fresh body weight, feed ration, oxygen consumption and amonia production in two experimental periods.

\begin{tabular}{|c|c|c|c|c|c|c|c|c|c|}
\hline $\begin{array}{l}\text { exp. } \\
\text { period }\end{array}$ & $\begin{array}{c}\text { weight } \\
\mathrm{g}\end{array}$ & $\begin{array}{c}\text { initial } \\
\text { body a } \\
\text { protein } \\
\%\end{array}$ & $\begin{array}{l}\overline{p o s .} \\
\text { fat } \\
\%\end{array}$ & $\begin{array}{l}\text { feed } \\
\text { ration } \\
(g / 28 d)\end{array}$ & $\begin{array}{l}\text { weig } \\
g\end{array}$ & $\begin{array}{l}\text { enmin: } \\
\text { body } \\
\text { protei } \\
\%\end{array}$ & $\begin{array}{c}\text { pos. } \\
\text { fat } \\
\%\end{array}$ & cons. & $\begin{array}{l}\mathrm{NH}_{3} \\
\text { prod. }\end{array}$ \\
\hline 1 & $\begin{array}{r}10.2 \\
9.4 \\
9.8 \\
10.3 \\
9.9\end{array}$ & $\begin{array}{l}14.6 \\
15.1 \\
14.6 \\
14.6 \\
14.6\end{array}$ & $\begin{array}{l}3.9 \\
4.5 \\
3.9 \\
3.9 \\
3.9\end{array}$ & $\begin{array}{r}2.0 \\
9.1 \\
9.1 \\
20.7 \\
37.8\end{array}$ & $\begin{array}{l}12.3 \\
25.3 \\
25.8 \\
44.9 \\
54.0\end{array}$ & $\begin{array}{l}14.3 \\
14.7 \\
14.0 \\
14.1 \\
14.6\end{array}$ & $\begin{array}{l}3.3 \\
5.6 \\
4.8 \\
6.5\end{array}$ & $\begin{array}{l}0.2 \\
2.4 \\
2.2 \\
4.8 \\
6.4\end{array}$ & $\begin{array}{l}0.04 \\
0.13 \\
0.13 \\
0.23 \\
0.58\end{array}$ \\
\hline 2 & $\begin{array}{l}54.6 \\
51.8 \\
57.2 \\
60.6 \\
53.8\end{array}$ & $\begin{array}{l}15.5 \\
15.1 \\
15.5 \\
15.5 \\
15.5\end{array}$ & $\begin{array}{l}4.3 \\
4.5 \\
4.3 \\
4.3 \\
4.3\end{array}$ & $\begin{array}{r}6.8 \\
23.1 \\
26.5 \\
59.8 \\
83.9\end{array}$ & $\begin{array}{r}59.8 \\
85.6 \\
98.7 \\
139.5 \\
140.8\end{array}$ & $\begin{array}{l}15.3 \\
14.6 \\
15.0 \\
15.5 \\
15.5\end{array}$ & $\begin{array}{l}35 \\
4.5 \\
4.7 \\
7.7 \\
9.5\end{array}$ & $\begin{array}{r}0.7 \\
4.7 \\
6.0 \\
12.3 \\
13.5\end{array}$ & $\begin{array}{l}0.08 \\
0.29 \\
0.28 \\
0.53 \\
0.82\end{array}$ \\
\hline
\end{tabular}

Fish meal, experiment 1.

The results of simulation and experiment obtained in the two periods refering fresh weight gain. protein gain and fat gain in relation to the feed ration are summarized in figures 1, 2 and 3.

At low feeding levels fresh weight gain, protein gain and fat gain increased with increasing ration size. The smaller fish in the first period had a slightly better feed conversion and protein conversion efficiency than the bigger ones in the second period. The output of the simulation model agreed well with experimental results for feeding levels providing submaximum weight gain. At the highest feeding levels, fresh weight gain and protein gain were similar for simulation and experiment and did hardly increase with increasing feed ration. According to the model calculations fat gain at the highest feed rations should level of, as fresh weight gain and protein gain did. However, the fat gain as determined in the experiment increased at increasing feed rations for all feeding levels. This caused a substantial increase of the fat content of the biomass at increasing feed rations. 


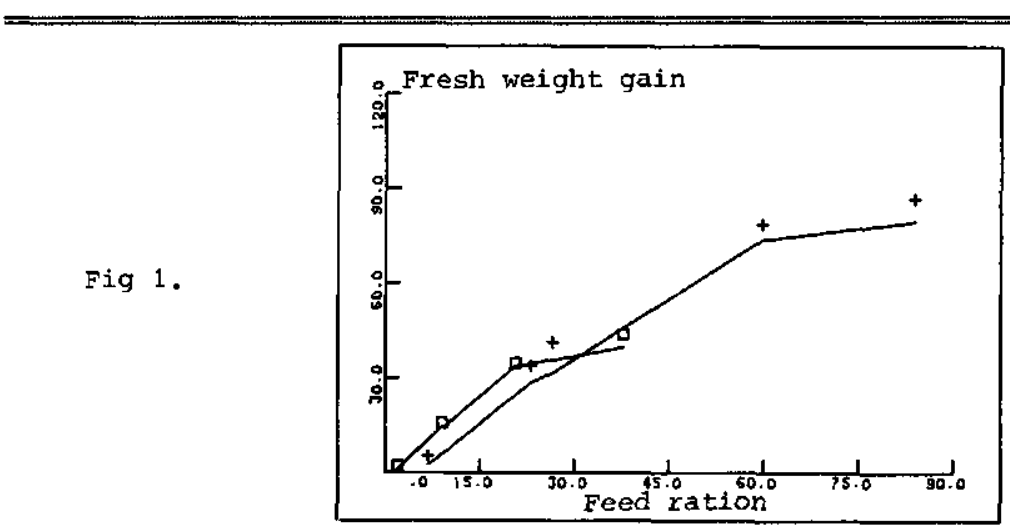

Fig 2.

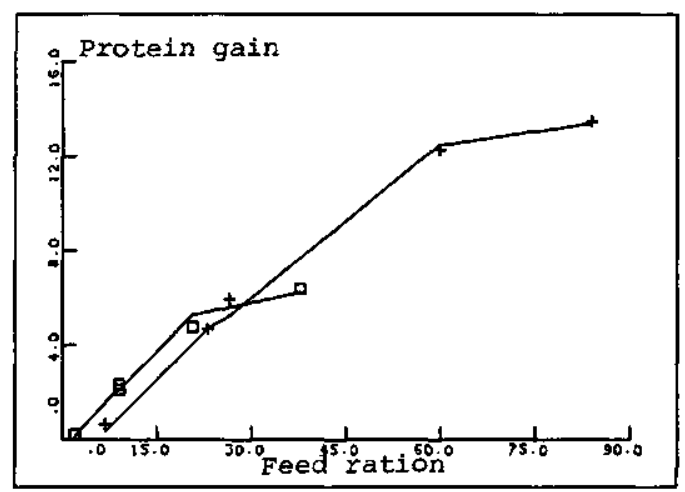

Fig 3.

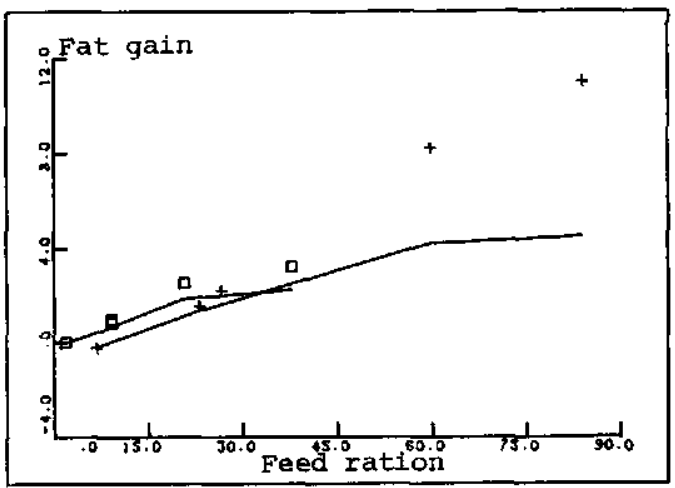

Figure 1-3. Fresh weight gain, protein gain and fat gain ( $g /$ fish per 28 days) in relation to the feed ration ( $/$ fish per 28 days) in two periods of experiment 1 and the comparable output of the simulation model (dram lines). : first period; : second period. 
Fig 4.

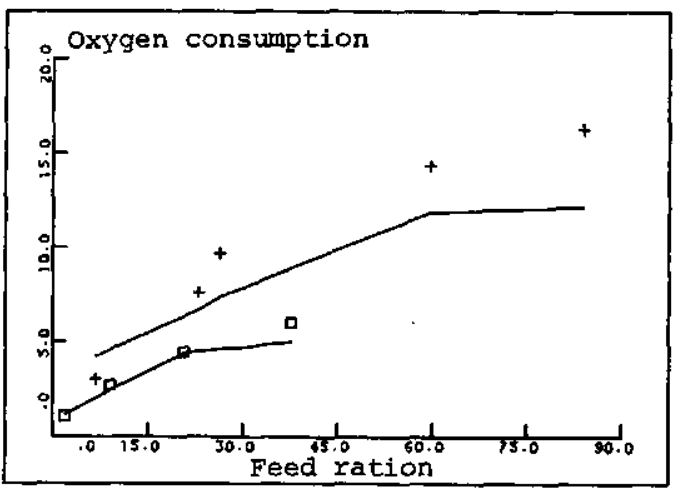

Fig 5.

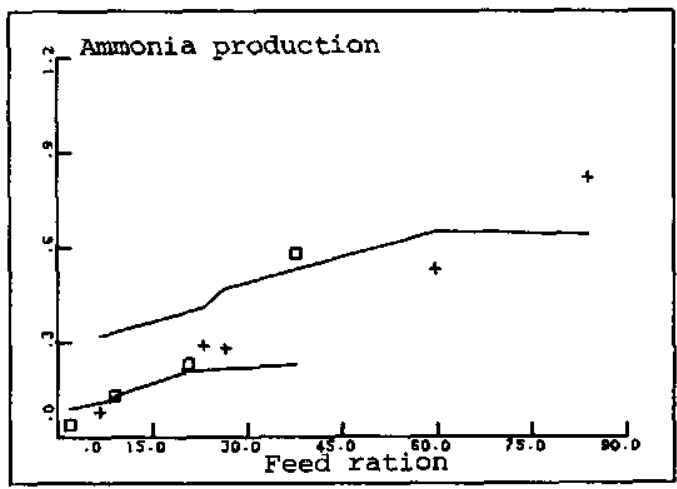

Figure 4 and 5. Oxygen consunption (1/fish per 28 days) and ammonta production ( $g /$ fish per 28 days) in relation to the feed ration ( $g /$ fish per 28 days) in two periods of experiment 1 and the camparable curput of the sinulation model (drann lines). Syntols as in figures $1-3$. 
The oxygen consumption in relation to the feed ration is given in figure 4. The oxygen consumption increased with increasing feed ration at low feeding levels similar to fresh weight gain and protein gain. The oxygen consumption leveled of at the highest feeding levels. The oxygen consumption per gram of feed consumed was less for the smaller fish in the first period than for the larger ones in the second period. Comparison of simulation results and experimental data for oxygen consumption showed good agreement, except for the highest feeding levels in the second experimental period, where the simulation results were lower than the experimental data.

The ammonia production in relation to the amount of feed given is shown in figure 5. At increasing feed rations the ammonia production increased. A considerable difference between the simulation results and the experimental data was found when the amount of ammonia production per gram feed intake was compared for both perfods. In the simulation the ammonia production depends on both the fish weight and the feed ration, and consequently is higher for the larger fish and for the high feed rations. The experimental results suggest that the ammonia production depends on the feed ration only.

Alternative protein sources, experiments 2,3 and 4.

The results of the calculations with the simulation model, as well as the experimental results, for fresh weight gain in relation to the different mixtures of protein sources are presented in figure 6 . The effect of amino acid supplementation was positive both in the experiments and in the simulation. The positive effect was small except for the experimental results of 2 groundnut diets $(100 \%$ and $50 \%)$. Therefore, only the results of the treatments without amino acid supplementation are presented in this figure. The results of a treatment will be discussed in relation to the result of the $100 \%$ fish meal control diet in the same experiment, because initial body weight, body composition, feeding level and temperature differed for each experiment.

A comparison of simulated and experimental results for the $100 \%$ fish meal control diets shows an overestimation of the experimental results in the simulation for experiment 2 and the first period of experiment 4, while the results were underestimated for experiment 3 and the second period of experiment 4. 
Table 5. Results of experiment 2. Initial and terminal body weight, chemical composition of initial and tentinal samples, feed ration, feed conversion and protein productive value for the two experimental periods. Mean and standard deviation (in parentheses) of the replicates per treatment

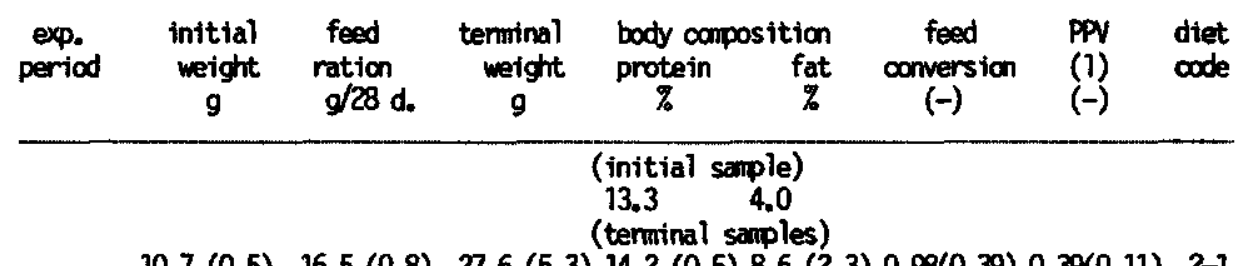

$10.7(0.5) \quad 16.5(0.8) 27.6(5.3) 14.2(0.5) 8.6(2.3) 0.98(0.39) 0.39(0.11) 2-1$

$8.7(1.6) \quad 14.6(2.8) \quad 2.4(3.8) \quad 14.1(0.8) \quad 5.6(1.5) \quad 1.06(0.03) \quad 0.34(0.02) \quad 2-3$

$10.6(0.9) \quad 16.0(1.6) 24.3(5.4) \quad 14.0(0.7) 6.6(0.3) \quad 1.18(0.50) \quad 0.33(0.06) \quad 2-4$

$9.9(0.3) \quad 16.7(0.5) \quad 29.9(2.7) \quad 14.5(0.5) \quad 7.6(0.0) \quad 0.84(0.09) \quad 0.47(0.02) \quad 2-5$

$1 \quad 10.2(0.4) \quad 17.5(0.8) \quad 30.1(0.5) \quad 15.1(0.3) 7.1(0.5) \quad 0.88(0.09) \quad 0.47(0.02) \quad 2-6$

$12.0(0.5) \quad 22.5(0.7) \quad 42.6(4.0) \quad 14.8(0.3) \quad 8.2(0.3) \quad 0.74(0.07) \quad 0.53(0.03) \quad 2-7$

$9.2(2.0) \quad 15.3(3.4) \quad 23.6(4.6) \quad 15.3(0.4) 5.4(1.2) \quad 1.06(0.04) 0.42(0.00) \quad 2.8$

$9.1(1.8) \quad 16.2(3.8) \quad 30.3(5.4) \quad 15.2(0.2) \quad 7.0(0.6) \quad 0.76(0.04) 0.53(0.02) \quad 2-9$

$11.8(0.1) \quad 18.9(0.3) \quad 30.4(2.1) \quad 14.9(0.5) \quad 9.0(0.9) \quad 1.01(0.15) \quad 0.40(0.03) \quad 2-10$

$12.0(0.0) \quad 20.4(0.2) \quad 36.1(0.3) \quad 14.7(0.2) \quad 7.7(0.6) 0.85(0.02) 0.44(0.02) \quad 2-11$

$12.1(0.4) \quad 21.2(0.8) \quad 41.3(5.0) \quad 14.4(0.6) \quad 7.8(0.0) \quad 0.73(0.11) 0.50(0.04) \quad 2-12$

(initial sample)

$16.2 \quad 6.7$

(terminal sanples)

54.1 (1.4) $29.5(0.6) \quad 89.4(0.5) \quad 15.3(0.1) 7.1(0.4) \quad 0.83(0.04) \quad 0.42(0.02) \quad 2-1$

$50.8(1.1) \quad 28.0(0.9) \quad 76.4(3.6) \quad 15.2(0.3) 6.7(0.1) \quad 1.09(0.08) \quad 0.32(0.05) \quad 2-2$

$54.7(3.3) \quad 31.1(1.7) \quad 99.7(7.3) 15.4(0.1) 8.0(1.0) \quad 0.69(0.03) 0.53(0.03) \quad 2-3$

$54.2(2.0) \quad 31.0(1.3) \quad 96.3(7.9) \quad 14.5(0.5) 7.6(0.1) \quad 0.74(0.09) \quad 0.43(0.01) \quad 2-4$

$48.1(3.1) \quad 27.0(2.2) \quad 89.2(8.5) \quad 15.1(0.1) 6.9(0.2) 0.66(0.03) 0.52(0.03) \quad 2-5$

$2 \quad 50.6(1.2) \quad 29.0(1.7) \quad 94.9(4.0) \quad 15.2(0.1) 6.8(1.3) \quad 0.66(0.00) 0.53(0.01) \quad 2-6$

56.2 (4.2) $33.8(3.3) \quad 104.7(6.4) \quad 15.5(0.3) 7.4(0.4) \quad 0.70(0.04) 0.51(0.06) \quad 2-7$

$\begin{array}{llll}47.7(0.1) \quad 26.5(0.3) & 84.6(1.0) \quad 15.6(0.4) 6.1(0.5) \quad 0.72(0.03) & 0.54(0.05) \quad 2-8\end{array}$

$52.9(1.9) \quad 28.6(2.3) \quad 97.0(3.9) \quad 15.6(0.3) \quad 6.5(0.1) \quad 0.65(0.02) \quad 0.60(0.01) \quad 2-9$

$61.1(2.0) \quad 34.4(1.3) 105.8(5.4) \quad 15.6(0.2) 6.6(0.8) 0.7(0.03) 0.50(0.04) \quad 2-10$

$57.2(8.2) \quad 31.9(4.0) \quad 706.4(18.4) \quad 15.5(0.3) 8.0(1.4) 0.65(0.08) 0.54(0.03) \quad 2-11$

$55.2(3.0) \quad 30.9(1.3) 103.1(6.9) \quad 15.5(0.1) \quad 7.3(0.2) \quad 0.65(0.03) \quad 0.54(0.03) \quad 2-12$

(1) PPV:productive protein value = protein gain/protein intake 
Table 6. Results of experiment 3. Initial and terminal body meight, chemical composition of initial and teminal samples, feed ration, feed corversion and protein productive value for the two experimental periods. The chenical composition of the terminal sample of the first period is identical with the chemical body composition of the initial sample of the second period. Mean and standard deviation (in parentheses) of the replicates per treatment

\begin{tabular}{|c|c|c|c|c|c|c|c|}
\hline $\begin{array}{l}\text { exp. } \\
\text { period }\end{array}$ & $\begin{array}{c}\text { initial } \\
\text { weight } \\
g\end{array}$ & $\begin{array}{l}\text { feed } \\
\text { ration } \\
g / 28 \mathrm{~d} .\end{array}$ & $\begin{array}{c}\text { tenminal } \\
\text { weight } \\
g\end{array}$ & $\begin{array}{c}\text { body composition } \\
\text { protein fat } \\
\%\end{array}$ & $\begin{array}{l}\text { feed } \\
\text { comversion } \\
(-)\end{array}$ & $\begin{array}{l}P P V \\
(1) \\
(-)\end{array}$ & $\begin{array}{l}\text { diet } \\
\text { code }\end{array}$ \\
\hline
\end{tabular}

\section{(initial sample)}

$\begin{array}{ll}14.2 & 2.6 \\ \text { (tenminal samples) }\end{array}$

$9.0(0.1) 41.6(-) 34.3(2.6) 15.3(0.6) 6.0(0.2) 1.64(0.15) 0.27(0.01) \quad 3-1$

$8.1(0.8) 41.6(-) 28.5(6.6) 15.2(0.3) 6.6(0.2) 2.04(0.42) 0.21(0.05) 3-2$

$9.3(0.6) 41.6(-) \quad 43.3(5.8) 15.7(0.5) 6.1(0.2) 1.23(0.18) 0.32(0.04) \quad 3-3$

$7.9(0.6) 41.6(-) 42.7(3.4) 15.1(0.2) 6.0(0.0) 1.20(0.09) 0.32(0.02) \quad 3-4$

$8.2(0.1) \quad 41.6(-) \quad 53.1(0.6) 15.2(0.2) 6.7(0.3) 0.93(0.01) 0.44(0.00) 3-5$

$18.7(0.0) \quad 41.6(-) 50.9(2.5) 14.7(1.4) 6.8(0.1) 0.99(0.05) 0.39(0.03) \quad 3-6$

$8.2(0.0) 41.6(-) 35.7(0.8) 15.0(0.3) 6.1(0.4) 1.51(0.05) 0.26(0.00) 3-7$

$9.2(1.5) \quad 41.6(-) \quad 35.5(0.5) 15.3(0.2) 5.8(0.1) 1.58(0.06) 0.26(0.00) 3-8$

$8.9(0.1) \quad 41.6(-) \quad 46.3(2.2) 14.9(0.1) 6.9(0.9) 1.11(0.07) 0.34(0.02) \quad 3-9$

$8.9(0.4) 41.6(-) 42.5(3.8) 15.0(0.0) 6.8(0.5) 1.24(0.14) 0.32(0.03) 3-10$

$37.0(3.0) 83.4$ ( - ) $89.5(4.1) 15.8(0.4) 7.7(0.9) 1.59(0.26) 0.29(0.02) \quad 3-1$

$32.4(5.3) 83.4$ ( - ) $82.2(3.1) 15.5(0.5) 8.4(0.3) 1.68(0.37) 0.26(0.03) \quad 3-2$

$44.6(5.0) 83.4(-) 128.1(7.7) 16.0(0.3) 8.0(0.3) 1.00(0.19) 0.40(0.04) \quad 3-3$

$46.0(1.4) 83.4$ ( - ) $129.0(17.8) 15.4(0.8) 7.9(0.4) 1.00(0.35) 0.39(0.06) \quad 3.4$

$57.5(1.0) 83.4$ ( - ) $144.8(17.0) 15.6(0.6) 8.7(0.3) 0.96(0.24) 0.44(0.05) \quad 3-5$

$2 \quad 48.6(2.5) \quad 83.4(-) 131.4(7.8) 16.0(0.2) 8.6(0.1) 1.01(0.15) 0.43(0.02) \quad 3-6$

39.4 (1.5) 83.4 ( - ) $98.6(20.4) 15.8(0.2) 7.7(1.2) 1.41(0.82) 0.30(0.09) \quad 3-7$

$38.4(1.5) \quad 83.4(-) \quad 81.4(3.6) 15.9(0.2) 7.4(0.2) 1.94(0.27) 0.22(0.02) \quad 3-8$

$44.5(1.2) 83.4(-) 121.4(11.5) 15.8(0.4) 8.4(0.7) 1.08(0.18) 0.38(0.04) \quad 3$

$42.0(0.4) 83.4(-) 110.8(4.0) 16.0(0.1) 8.6(0.1) 1.21(0.09) 0.36(0.03) \quad 3-10$

(1) PPV:productive protein value = protein gain/protein intake 


\begin{tabular}{|c|c|c|c|c|c|c|c|}
\hline \multirow[b]{2}{*}{$\begin{array}{l}\text { exp. } \\
\text { period }\end{array}$} & \multicolumn{6}{|c|}{$\begin{array}{l}\text { Table 7. Results of experiment 4. Initial and tenminal body weight, } \\
\text { chemical composition of initial and teminal samples, feed ration, feed } \\
\text { conversion and protein productive value for the two experimental peri- } \\
\text { ods The chemical composition of the terminal sample of the first period } \\
\text { is identical with the chemical body composition of the initial sanple } \\
\text { of the second period. Mean and standard deviation (in parentheses) of } \\
\text { the replicates per treatment }\end{array}$} & \multirow[b]{2}{*}{$\begin{array}{l}\text { diet } \\
\text { code }\end{array}$} \\
\hline & $\begin{array}{c}\text { initial } \\
\text { weight } \\
9\end{array}$ & $\begin{array}{l}\text { feed } \\
\text { ration } \\
g / 28 \mathrm{~d} \text {. }\end{array}$ & $\begin{array}{c}\text { temminal } \\
\text { weight } \\
\mathrm{g}\end{array}$ & $\begin{array}{l}\text { body composition } \\
\text { protein fat } \\
\%\end{array}$ & 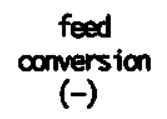 & $\begin{array}{l}\text { PPV } \\
(1) \\
(-)\end{array}$ & \\
\hline 1 & $\begin{array}{l}137.9(2.0) \\
143.3(13.8) \\
147.0(10.0) \\
143.7(27.9) \\
142.1(24.8) \\
147.7(16.1) \\
140.3(12.7) \\
142.3(8.6) \\
135.5(11.1) \\
149.7(5.7)\end{array}$ & $\begin{array}{l}85.6(1.6) \\
90.1(7.2) \\
89.3(2.5) \\
91.1(16.8) \\
90.0(14.6) \\
91.9(8.8) \\
89.7(7.6) \\
65.3(3.0) \\
85.0(4.8) \\
96.3(2.2)\end{array}$ & $\begin{array}{l}202.0(3.4) \\
216.3(17.5) \\
218.9(6.3) \\
222.5(38.5) \\
220.7(33.9) \\
223.4(12.8) \\
216.8(19.3) \\
201.9(5.4) \\
205.6(14.6) \\
235.1(5.4)\end{array}$ & $\begin{array}{l}\text { (initial sample) } \\
16.0 \quad 4.9 \\
\text { (terminal samples) } \\
17.8(1.3) 5.3(0.2 \\
17.0(0.5) 4.7(0.1 \\
16.6(0.3) 4.7(0.7 \\
16.4(0.2) 5.7(0.2 \\
16.6(0.3) 5.5(0.4 \\
15.0(0.7) 4.6(0.7 \\
15.4(0.6) 5.1(0.5 \\
16.1(0.4) 6.3(0.4 \\
15.8(0.0) 5.3(0.2 \\
15.5(0.5) 6.1(0.1\end{array}$ & $\begin{array}{l}1.34(0.0) \\
1.23(0.04) \\
1.24(0.09) \\
1.16(0.07) \\
1.15(0.06) \\
1.21(0.16) \\
1.17(0.0) \\
1.10(0.10) \\
1.21(0.01) \\
1.13(0.03)\end{array}$ & $\begin{array}{l}0.42(0.08) \\
0.38(0.03) \\
0.38(0.00) \\
0.38(0.00) \\
0.43(0.03) \\
0.30(0.10) \\
0.34(0.03) \\
0.37(0.06) \\
0.38(0.01) \\
0.38(0.04)\end{array}$ & $\begin{array}{l}4-1 \\
4-2 \\
4-3 \\
4-4 \\
4-5 \\
4-6 \\
4-7 \\
4-8 \\
4-9 \\
4-10\end{array}$ \\
\hline 2 & $\begin{array}{l}205.7(9.8) \\
209.0(9.5) \\
201.6(5.9) \\
217.7(29.4) \\
229.4(34.4) \\
250.7(27.4) \\
218.2(23.0) \\
200.4(8.1) \\
214.2(20.4) \\
235.3(13.2)\end{array}$ & $\begin{array}{l}138.2(7.8) \\
133.9(5.0) \\
134.9(6.5) \\
138.7(11.7) \\
160.1(24.0) \\
172.5(18.9) \\
150.2(16.3) \\
102.0(0.8) \\
144.8(12.5) \\
163.7(11.5)\end{array}$ & $\begin{array}{l}280.9(16.3) \\
257.8(5.3) \\
309.5(10.4) \\
311.5(30.9) \\
369.4(46.4) \\
332.9(38.2) \\
340.9(37.4) \\
285.4(14.7) \\
331.3(28.6) \\
332.1(30.8)\end{array}$ & $\begin{array}{l}17.9(0.4) 6.5(0.5 \\
17.6(0.1) 7.0(0.6 \\
17.7(0.2) 7.4(0.9 \\
17.5(0.1) 6.8(0.2 \\
17.8(0.4) 8.0(1.7 \\
17.0(0.5) 8.1(0.6 \\
16.5(0.2) 7.0(0.1 \\
17.5(0.3) 7.6(0.1 \\
16.8(0.2) 6.4(0.3 \\
16.7(0.5) 7.5(0.1\end{array}$ & $\begin{array}{l}1.84(0.06) \\
2.74(0.30) \\
1.25(0.01) \\
1.48(0.10) \\
1.14(0.08) \\
1.21(0.05) \\
1.22(0.01) \\
1.20(0.11) \\
1.24(0.0) \\
1.12(0.07)\end{array}$ & $\begin{array}{l}0.24(0.06) \\
0.18(0.04) \\
0.41(0.00) \\
0.34(0.02) \\
0.47(0.00) \\
0.46(0.05) \\
0.41(0.04) \\
0.43(0.03) \\
0.45(0.02) \\
0.48(0.01)\end{array}$ & $\begin{array}{l}4-1 \\
4-2 \\
4-3 \\
4-4 \\
4-5 \\
4-6 \\
4-7 \\
4-8 \\
4-9 \\
4-10\end{array}$ \\
\hline
\end{tabular}

(1) PPV:productive protein value = protein gain/protein intake 
In general fresh weight gain decreased at decreasing fish meal / alternative protein source ratios. For the simulation the ranking order of this decrease was soybean and rapeseed, casein, cottonseed, groundnut and blood meal. In the experiments this decrease was smallest for the soybean and casein diets, and greatest for the cottonseed and rapeseed diets, while the decrease for the blood meal diets was similar to the cottonseed diet in the first period and nearly constant at all replacement levels in the second period. Fish fed with a $75 \%$ soybean diet in the first period, a $50 \%$ soybean diet and a $25 \%$ casein diet in both periods and a $50 \%$ blood meal diet in the second period showed a higher fresh weight gain than the $100 \mathrm{z}$ fish meal control diets.

In the model no difference between the $100 \%$ fish meal diets with and without amino acid supplementation was found. In the experiments a minimal positive effect of amino acid supplementation was found for these diets. In experiment 3 the fresh weight gain was 2.9 and $0.6 \%$ higher in the first respectively the second experimental period, in case of amino acid supplementation.

Feed conversion and protein conversion efficiency were better in the second period of experiment 2 and 3 and in the first period of experiment. 4. These differences were relatively smaller for the simulation than for the experimental results.

The results for protein gain were similar to the results for fresh weight gain. The simflarity was less for fat gain. In the model fat gain depends on the feed composition (fat/protein ratio) and feeding level. which were almost the same per experiment and is practically independent of the protein source used. However, in the experiments an increase of fat gain was found with increasing fish meal levels.

The greatest discrepancy between model calculations and experiments was found for the second period, especially for the highest feeding levels (experiment 3 and 4 ), the simulated results being lower than the experimental ones. This discrepancy may be due to different parameter values for the regulation of the feed intake for these diets, because simulation and experiment in the second period coincide reasonably well if the maximum feed intake is increased $25 \%$. 


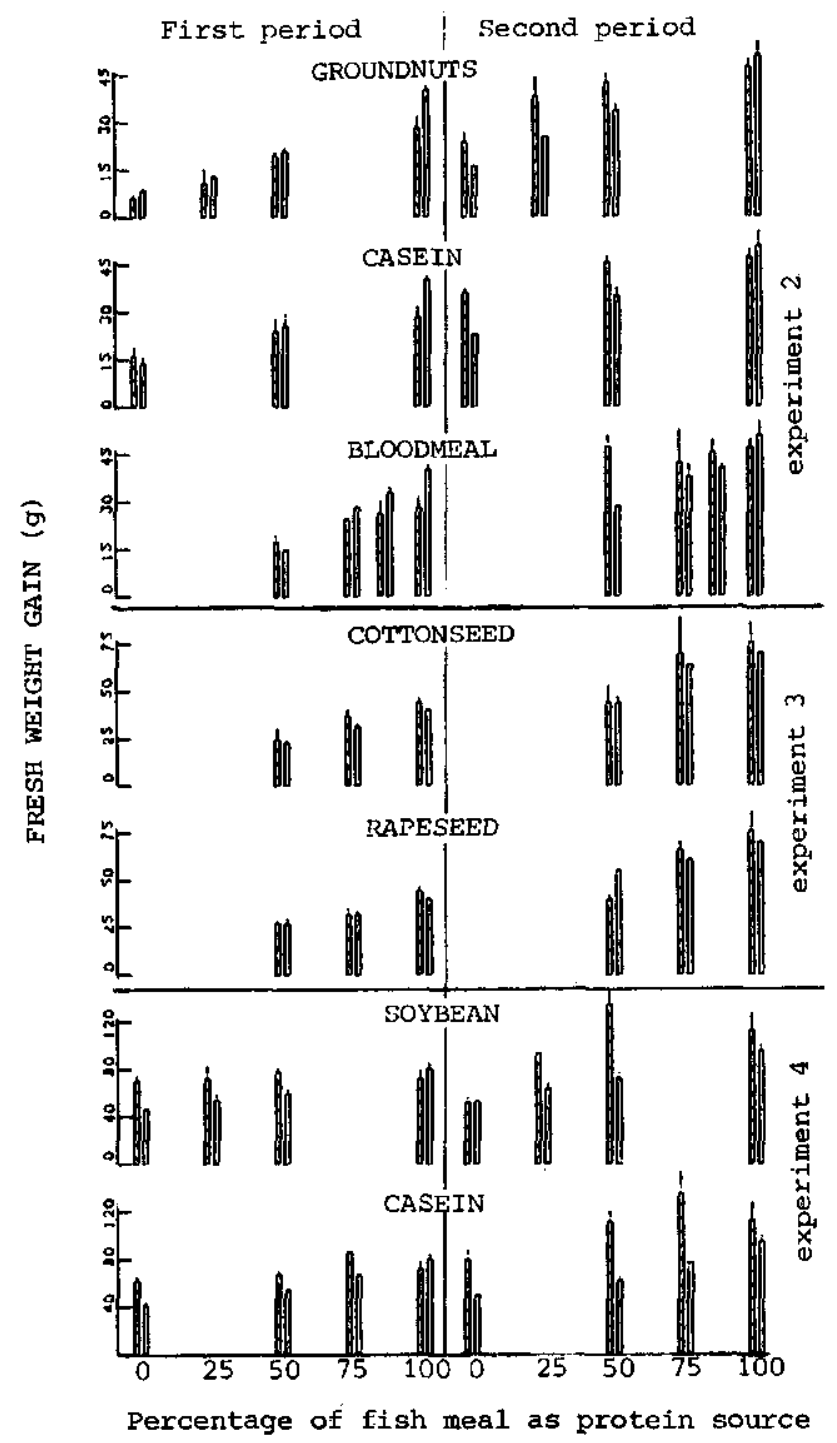

Figure 6. Fresh weight gain ( $g /$ fish per 28 days) in relation to the amount of protein which is supplted by fish meal as a percentage of the total, for the alternative protein sources in two experimental periods. Striped bars: experimental results. Open bars: results of simulation. 
The first experiment in this study indicated that $\underline{C}$. gariepinus is able to convert feed nutrients very efficiently into fish biomass. A protein conversion efficiency of $60 \%$ can only be reached in cases where the feed protein has a high biological value and digestibility. Moreover the feed must contain sufficient fat and/or carbohydrates to minimize gluconeogenesis of amino acids. However the fat and/or carbohydrate content in the feed influences the biomass composition, which in turn affects regulation of the feed intake (Machiels and Van Dam, 1987). In time the high fat content of the diet will decrease the maximum feed intake of the fish. The initial fat content of the fish was too low and the experimental period was too short, to verify the reduction of the maximum feed intake in this experiment.

While fresh weight gain and protein gain were constant at the highest feeding levels in experiment 1 , the fat gain still increased at the highest feed intake levels. In experiment 3 and 4 high feeding levels were used and the fat gain, calculated with the model, was an overestimation of the experimental results. This indicates that at these feeding levels the fish still eats extra amounts of feed but utilizes only the fat or the protein in the feed for fat synthesis via lipogenesis. The effect of these processes will be the same. Both will cause an increase in oxygen consumption at the highest feeding levels. which was found in the respiration experiment. If body composition is a major production goal this could be important in practical fish culture. However, if the fresh weight gain is the only production goal such feeding levels are too high to be economical.

Clay (1981) determined soluble nitrogen excretion for individually housed c. gariepinus. For fasting fish the excretion amounted $0.0055 \mathrm{mg}$ $\mathrm{N} / \mathrm{g} / \mathrm{h}$. It means that the ammonia production will vary according the fish weight. The model used here also predicts a difference in ammonia production for the two weight classes in the respective experimental periods, but the measured ammonia production suggest a strong dependency on the feed ration on $1 y$. It may be concluded that the experimental procedure measuring the ammonia production was incorrect. The faeces and the feed rests were not separated from the tanks immediate1y. In the sedimentation funnels of the tanks ammonification and nitrification can take place, thereby changing the amount of ammonia in 
the water. which interferes with the measurement of the amonia production of the fish.

The decrease in fresh weight gain with increasing amounts of fish meal being replaced by an alternative protein source can be caused by a number of factors. One reason for the reduced performance of the diets with increasing levels of the alternative protein sources may have been a lower digestibility of these sources. Research of Wilson et al. (1981) showed that the variability of digestibilities for different alternative protein sources $(83.3 \pm 6.6)$ was as great as the variability of two types of fish meal $(79.3 \pm 9.6)$. An alternative protein source can have a completely different amino acid profile compared to fish meal. When fish meal is replaced by such a protein source an essential amino acids deficiency is possible. In such a case the fresh weight gain will decrease because the biological value of the diet protein and thereby the protein conversion efficiency is decreasing. The effect of supplementation of amino acids was not high enough to get equal results as the control diets. It seems that protein requirements of C. gariepinus are met if the amino acid profile of the feed protein agrees with the amino acid composition of fish meal protein. For some other fish species this was also noticed (Tacon and Cowey, 1985).

The possibilities of a fish to adapt to change of the protein source in the diet are not clear (Cowey and Sargent, 1978). For carp it was shown that the activities of enzymes concerned in the degradation of the essential amino acid histidine depend on the histine concentration in the diet. If this phenomena holds also for $\mathrm{C}$. gariepinus and other essential amino acids, the rate of amino acid degradation of the labile protein can be controlled by a sudden change in amino acid composition of the protein in the diet. If the fish is able to conserve an essential amino acid, the protein efficiency of an amino acid deficient diet would be temporary better than expected from the amino acid profile of that diet. A higher protein turnover in small fish will shorten the duration of this temporary effect. In case different fish were used in the two experimental periods, the protein efficiency was better in the second period compared to the first period were smaller fish were used. If the same fish were used in both periods the results of the first period were better. This indicates that a feeding period for testing protein in fish diets should at least last two month. depending on the initial fish weight. The hypothesis stated above can explain part of the discrepancy between calculated and experimental 
results. The model calculations are based on a static approach of biosynthesis of body protein from feed protein, both with a constant amino acid composition. However. protein conversion seems to be subject to dynamic changes in the protein metabolism.

The reduced weight gain, found for the higher inclusion levels of the alternative protein sources could be caused by toxic components. like an anti-trypsin factor in soybean, or by a lower appetite for diets with alternative protein sources. Growth will be reduced when the concentration of toxic components exceeds a certain limit. In that case inclusion level of the protein source with the toxic component and feeding level determine wether the limit is exceeded. Palatability of the diet plays an important role if high feeding levels are used. No clear statement can be made which factor probably caused the growth reduction in this experiment, since only one feeding level was offered to the fish. Therefore, diet ingredients should be tested at a range of feed rations in order to discriminate between the possible factors causing reduced weight gain at high inclusion levels of the alternative protein sources.

Soybean and casein seems to be good alternatives as basic components of the protein in the fish diet. Although in fish nutrition research, casein is often used as a protein source because of its purity and constant quality, its use is considered less suitable because of its high price. In addition, the experiments described here, indicate that growth results for casein diets are inferior to fish meal diets. Extrapolation of results of nutrition research based on casein diets to practical conditions, where mostly diets based on other ingredients (e.g. fish meal) are used, need a correction, which depends on the feed ingredients used. Other alternative protein sources can be considered for supplementation in smaller quantities. Addition of some ingredients can increase the biological value of the total protein if its protein contains a surplus of a specific amino acid, which is limiting in the other ingredients.

A diet is correctly formulated if it supplies the animal with those quantities of nutrients which are required for optimal production (Van Es, 1976). Optimal production can be defined from a biological or an economical viewpoint. A biological optimum may be achieved if the diet is formulated in such a way, that the lowest allowable levels for protein (amino acids), fat (fatty acids), carbohydrates and micro nutrients ensuring the animal well being are included. If the intake of 
nutrient guaranties the fish farmers, maximal profit, then an economical optimum is reached. The feed formulation for both optimums will seldom be the same. Calculations with a model as presented in this series can heip to develop the biologically optimal feed formulation for different nutrient sources available and for different environmental circumstances. The ultimate choice of the feed depends on the intensity of the culture process and its economics. For the latter purposes the model output can be used in combination with linear programing techniques. The simulation model is suited to predict the influence of fat, protein and carbohydrate supply on the performance of C. gariepinus, based on the chemical composition of the feed and the fish biomass. For feed formulation purposes it seems possible to calculate a ranking order of ingredient to be included in the diet, based on the chemical composition of the ingredients. A precise estimate of the amino acid composition of the protein sources and of the fatty acid composition of the fat is needed for accurate predictions.

\section{REFERENCES}

Cowey, C.B. and Sargent, J.R., 1979. Nutrition. In: W.S. Hoar, D.J. Randall and J.R. Brett (Editors), Fish Physiology, Vol. VIII. Bioenergetics and growth. Academic Press. New York, op. 1-70.

Janssen, W.M.M., Terpstra, K., Beeking, F.F.E. and Bisalsky, A.J.N.. 1979. Feeding values for poultry. Spelderholt Mededelingen 303. Published by Spelderholt Institute for Poultry Research. Beekbergen - Netherlands. pp. 59.

Henken, A.M., Machiels, M.A.M., Dekker, W. and Hogendoorn, H., 1986. The effect of dietary protein and energy content on growth rate and feed utilization of the African catfish Clarias gariepinus (Burchell 1822). Aquaculture, 58: 55-74.

Hogendoorn, H., 1979. Controlled propagations of the African catfish, Clarias lazera (C.\&V.). I. Reproductive biology and field experiments. Aquaculture, 17: 323-333.

Hogendoorn, H.. 1980. Controlled propagations of the African catfish, Clarias lazera (C.\&V.). III. Feeding and growth of fry. Aquaculture, 21: $233-241$. 
Hogendoorn, H., Jansen, J.A.J., Koops, W.J., Machiels, M.A.M., van Ewijk, P.H, and van Hees, J.P., 1983. Growth and production of the African catfish, Clarias lazera (C.\&V.) . II. Effects of body weight, temperature and feeding level in intensive tank culture. Aquaculture, 34: 265-285.

Hogendoorn, H., Van Korlaar, F. and Bosch, H., 1981. An open circuit balance respirometer for bioenergetic studies of fish growth. Aquaculture, 26: 183-187.

Hogendoorn, H. and Vismans, M.M.. 1980. Controlled propagations of the African catfish, Clarias lazera (C.\&V.). II. Artifical reproduction. Aquaculture. 21: 39-35.

Machiels M.A.M. and Henken, A.M., 1985. Growth rate, feed utilization and energy metabolism of the African catfish. Clarias gariepinus (Burchell 1822) as affected by dietary protein and energy content. Aquaculture 44: 271-284.

Machiels, M.A.M. and Henken, A.M., 1986. A dynamic simulation model for growth of the African catfish, Clarias gariepinus (Burchell 1822). I. Effect of feeding level on growth and energy metabolism. Aquaculture, 56: 29-35

Machiels, M.A.M. and Henken. A.M.. 1987. A dynamic simulation model for growth of the African catfish, Clarias gariepinus (Burchell 1822). II. Effect of feed composition on growth and energy metabolism. Aquaculture, 60: 33-54

Machiels, M.A.M. and Van Dam, A., 1987. A dynamic simulation model for growth of the African catfish, Clarias gariepinus (Burchel1 1822). III. Effect of body composition on growth and feed utilization. Aquaculture. 60: 55-71.

Moore, L.B.. 1985. The role of feeds and feeding in aquatic animal production. GeoJournal, 10.3: 245-251.

NEN, 1977. Chemical analysis. Directives for determinations. Nederlands Normalisatie Instituut 1966-1975 NEN 3104, Rijswijk. The Netherlands. NRC. 1977. Nutrient requirements of warmwater fishes. National Research Council - National Academy of Science, Washington, DC. 78 pp.

Tacon, A.G.J and Cowey, C.B., 1985. Protein and amino acid requirements. In: $P$. Tytler and $P$. Calow (Editors), Fish energetics: new perspectives. Croom Helm London \& Sidney. pp 155-184. 
Van Es. A.J.H., 1976. Unique problems in diet formulation. In: P.V. Fonnesbeck. L.E. Harris and L.C. Kearl (Editors), proceedings of the first international symposium on feed composition, animal nutrient requirement and computerization of diets, Utah agr. exp. sta.. Utah state University. Logan, Utah, USA pP 15-21.

Wilson. R.P.. Robinson, E.H. and Poe, W.E., 1981. Apparent and true availability of amino acids from common feed ingredients for channel catfish. Journal of Nutrition 111: 923-929. 
GENERAL DISCUSSION

In this thesis a dynamic growth model, based on theoretically derived components is described. The theoretical concept is the partition of the nutrient intake of Clarias gariepinus into its basic key components amino acids, glucose and fatty acids. Basic knowledge of the biochemistry in the intermediate metabolism, with respect to biosynthesis and respiration, is used to calculate fish growth.

One of the most important questions in fattening of fish is "what to feed how much". By developing a growth model this question was tried to answer. A model is an efficient mean to examine the interrelationships between the constituents of the system studied. A model can also demonstrate the connections between and the mutual influences of growth determining factors. In the process of developing this simulation model for growing $\mathrm{C}$. gariepinus some 20 important variables were defined. The potential amount of data which becomes available by combination of these variables is enormous. To obtain the same information solely from field experiments, would be very time consuming and expensive. It is beyond the scope of this thesis to examine all these variables in all possible combinations and sometimes assumptions had to be made. However, the model developed offers the possibility of predicting the per-

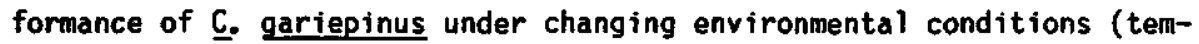
perature), body compositions, feeding procedures, diet compositions and feed formulations. The results were already discussed in the papers included in this thesis. In this chapter some general aspects of the model and its possible role in aquaculture will be discussed.

The basic approach, which was used to develop the model was applied earlier to plant growth and nutrition studies (Penning de Vries, 1973). Oko (1979) used a similar approach for simulating pig growth. The generality of a great part of the model is of major advantage because with some minor changes the model can be adapted for other fish species. The biochemistry of fishes has not been studied enough for a presentation of a complete set of biochemical pathways for biosynthesis and respiration. Therefore, it was necessary to include general biochemical pathways, which are mainly based on observation on microorganisms. The pathways to obtain a certain end product from a given nutrient composition are expected to differ not very much among 
organisms (Penning de Vries et al., 1974). The conversion from feed nutrients to fish biomass is characterized to a great extent by the amount of the main nutrients protein. fat and carbohydrate in the diet. Within these main nutrient fractions the conversion is similar. The chemical composition within a main fraction, like for instance the amino acid composition of dietary protein is of minor importance in normal growth studies. In feed formulation studies, however, lack of knowledge of the chemical composition within such a main fraction can cause a notable inaccuracy of the result of the simulation.

The requirements for the dietary amino acid composition is calculated from the chemical composition of the protein in the fish biomass. It is assumed that the whole body protein is ideally balanced for growth, which implies that the amino acids composition of the protein used for maintenance is similarly balanced as the whole body protein. If their are differences in amino acid requirements between maintenance and biosynthesis, then the effect is probably small, because the maintenance requirements of fish is low compared with warm blooded animals. No basic data about the maintenance requirements of fish could be collected from the literature. An inaccuracy of the estimate of the maintenance metabolism from experimental results can influence the result of the calculation, specially at the lower feeding levels.

Another gap in knowledge was found for the growth at the highest feed intake levels. Although some hypotheses have been formulated for feed intake regulations, the suitability of the model at the upper limits of growth and/or feed intake levels is subject to some doubt. Moreover the model is very sensitive for changes in the maximum feed intake. Therefore, future emphasis must be given to find an adequate relation for predicting the maximum feed intake levels. Various mathematical models estimating the daily feed consumption of fish are available (Jobling, 1986). However, improvement of the model must not come from a better statistical fitting of given data, but from a better understanding of the processes which control the feed intake physically and physiologically.

The modeling results indicate that $\underline{C}$. gariepinus is an efficient convertor of diet nutrients. Only when large quantities of carbohydrates or fat are included in the diet, problems occur due to a low maximum feed intake level. Obviously the fish uses efficient biochemical pathways for biosynthesis of the biomass and, therefore, it may not be highly rewarding -as can be determined by this model- to accelerate 
growth by changing the efficiency of biosynthesis through genetic improvement. Selection should emphasise on a lower maintenance requirement, on maximum intake of nutrients by fast growing animals or on a resistance to diseases and stress under culture conditions.

Besides provision of information on the physiological consequences of genetic improvement, the model can be used for different other purposes as well.

The model can be used for research and teaching on the principles of nutrient utilization and growth of fish. The calculations can identify sensitive areas within the growth process where theoretical and/or experimental information is lacking and provide a direction for future research.

As the model also gives information about the gas exchange and formation of metabolic waste like ammonia, it can help to analyze the growth process of the fish -without the need for slaughter experimentsby monitoring these parameters and use their values as input for the model.

In nutrition studies the model can help developing 'tailor made' fish diets to optimize the yield of individual farms. In that case the model is used in a comparative way to allow a ranking order of mixed diets, according to the diet composition, diet protein quality and the nutrient requirements of the fish cultured. It must be realized that the nutrient requirements for the major food constituents will vary according to feed ration and production purposes. With the use of a model the problems can be reanalyzed whenever major changes occur, in contrast with recommendation based on traditionally derived feed requirements. Water quality management plays a key role in high intensive aquaculture. In fresh water, the water availability will often be a limiting factor for the expansion of the industry. The quantity and quality of the farm effluent affects the environment by causing pollution. Adequate diets must be developed with high conversion ratio's without causing substantial water quality deteriorations.

The model applies to growth of a single fish. When applied to a population, it is assumed that all individuals are of the same size and eat the same feed ration. This assumption of course is not a valid one. In some cases the variation in size may be of economical importance. If the nature of the variability is included in the model, the model becomes stochastic and could be used for the absolute prediction of the 
production, with -ultimately- testing of the real farm result. A model of the physical culture system describes the relationships in the culture environment. When combined with a growth model as described here, it completes the description of relevant aspects of the whole culture system (Allen et al., 1984). Such models should allow economic analysis of management alternatives for fish production.

Aquaculture occupies a relatively minor place in the overall economy of most countries, and is not a major protein supplier on a global scale. The greatest biological potential for aquaculture lies in tropical and subtropical areas, because the warm water temperature favors the growth of the fish. However, there is an urgent need of both technical and biological upgrading of aquaculture in these areas. In this context it must be stressed that C. gariepinus represent a fish species, which responds well to high technology techniques.

In human nutrition animal proteins are preferred over plant proteins due to the lower biological value of the latter. With direct consumption of plant protein by humans a loss of approximately $33 \%$ was calculated, due to an imbalance in the amino acid composition of the protein (Pirie, 1976). The use of fish as local plant protein convertors may not be as inefficient as that of warm blooded animals (Holmes, 1977). Warm blooded animals are capable to "concentrate" the protein of waste products with a low protein and high carbohydrate content. Investigation to find fish species, which can utilise low protein diets efficiently is warranted.

\section{REFERENCES}

Allen. P.G., Botsford, L.W., Schuur, A.M. and Johnston, W.E., 1984. Bioeconomics of aquaculture. Developments in aquaculture and fisheries science, Volume 13. Elseviers Amsterdam-0xford-New York-Tokio. 351 pp. Holmes, W., 1977. Choosing between animals. Phil. Trans. R. Soc. Lond. 8. 281: $121-137$. Jobling. M., 1986. Mystical models of gastric emptying and implications for food consumption studies. Environmental biology of fishes, 16(13): 35-50. 
Oko, A.. 1979. Simulation of nutritional-environmental interactions in a growing-finishing pig. Dissertation. The Ohio State University.

Pirie, N.W.. 1976. Food resources conventional and novel. Penguin Books Ltd, Harmondsworth, Middlesex, England. 256 pp.

Penning de Vries, F.W.T.. 1973. Substrate utilization and respiration in relation to growth and maintenance in higher plants. Dissertation, Agricultural University, Wageningen.

Penning de Vries, F.W.T., Brunsting, A.H.M. and Van Laar. H.H., 1974. Products, requirement and efficiency of biosynthesis: A quantitative approach. J. theor. Biol: 45:339-377. 
SUMMARY

In the early ' 70 it was tried to identify new fish species for aquaculture in Africa. Amongst the most promising candidates was the African catfish. Clarias gariepinus (Burchell 1822). It is an omnivorous fish, which means a wide feeding spectrum. The fish is a partial air breather, so the oxygen concentration in the water is no strongly limiting factor. which facilitates high density culture.

To provide the basis for a production programme of any species the various phases of its culture process must be elaborated. First of all methods for reproduction have to be established to ensure a reliable supply of fingerlings. Secondly raising of fingerlings to ftsh of marketable size is a field of major importance.

An important question in fattening of fish is what to feed how much. The amount and the composition of the fish diet have a pronounced effect on growth rate and feed conversion. The conversion process of feed nutrients into fish biomass is influenced by a number of biotic and a-biotic factors like for instance body weight, maturity, water temperature and water quality. Many experiments are required to perform dose-respond relationships for the amount of feed and the weight gain at different temperatures, different weight classes and various diet compositions. To reduce these efforts developing a growth model may be helpful.

In this study an explanatory growth model is developed to gain knowledge about the influence of various factors on the growth process. The quantitative equations of the model describe the processes at the underlying levels of growth, the intermediate metabolism and biochemistry. These equations reflect our understanding and knowledge of the relationship in the real system.

To carry out the simulation the state variable approach is used. All rates of change between small time lags are calculated from the conditions of the system at time of start and if necessary from data in the past. The state of the system can be calculated by semi-parallel integration over the small time interval. From these new circumstances the calculations are repeated. 
The model calculations start with the amount of various digested nutrients. The digestion rate of the various nutrients depends on the eating rate, the diet composition and the digestion efficiency. The resulting amino acids, fatty acids and mono sacharides (glucose) are the building blocks for biosynthesis of new biomass. Apart from the composition of digested nutrient the conversion process of feed nutrients into fish biomass also depends on the composition of the biomass. Because the glycogen content in fish is very low it is assumed that glucose and fatty acids are converted to fat. The amino acids are used for the biosynthesis of protein. Since fish has to maintain its body composition within certain limits, more or less amino acids are used for other purposes via gluconeogenesis, depending the diet composition.

Using the biochenical pathways, as given in the literature, of biosynthesis and other metabolic processes a molecular reaction equation can be made, giving the substrate required for any particular end product. The reaction equations generally include ATP and other recycling intermediates for energy transformations. The final equations for the most complex substrate and end products represent the efficient conversion possible, given the biochemical "machinery". The converstion process is easily expressed in terms of weight of substrate and end products formed. The reactions also include the gas exchange.

The new fish biomass formed by biosynthesis is not all weight gain, because part of the biomass is broken down for respiration purposes. Respiration is determined by the total metabolic rate. The total metabolic rate is the sum of the routine metabolic rate at fasting conditions, the metabolic rate due to feed intake and assimilation and the metabolic rate for the biosynthesis of biomass. The ratio at which body fat and protein are oxidized for respiration is set to depend on the body composition in order to avoid unrealistic body compositions.

The change in the amounts of different body constituents is calculated as the difference between biosynthes is and breakdown for respiration. When the protein gain is known. fresh weight gain is calculated with a relation between body weight and protein content. The fat gain is considered to affect the body composition only. The fat and the water content of fish biomass show a strong negative correlation. 
Feed consumption by the fish is determined by the daily feed ration. Since at high feeding levels a difference between amount of feed consumed and amount of feed provided may occur, a relation between maximum consumption and fish weight at different temperatures is incorporated in the model in order to limit the weight gain in such circumstances. In the model, the maximum feed intake by the fish is also controlled by the composition of both the fish biomass and the diet. Fat fish can consume less feed than a leaner fish of the same weight. A fish will also eat less in case of a carbohydrate rich diet.

The input needed for the calculations are body weight and fat content of the fish, amount and composition of the feed and the water temperature. The output of the model includes fresh weight gain, protein gain, fat gain, oxygen consumption, carbon dioxide production and ammonia production.

During its development the model was tested by comparing the model output with experimental results which were not used during the calibration procedure.

Firstly a comparison was made with results of an experiment were a diet with a fixed composition was offered to different weight classes of . gariepinus at 3 temperatures and 5 feeding levels. A second comparison was made with result of an experiment were diets with different composition were fed to the fish. The model estimates the effects of feeding level, feed composition (in particular protein and fat content) and temperature on growth and growth composition reasonably well. The test results indicate that $\underline{C}$. gariepinus utilises the feed nutrients at maximum biochemical efficiency. It became also apparent that the fish regulates its maximum feed intake by the fat content of the biomass. Because there were no data available to support this hypothesis, an experiment was carried out to determine the effects of body composition on growth and feed intake. In this experiment it was shown that feeding a diet to lean or fat fish, resulted in a higher maximum gain for lean fish due to a higher maximum feed intake level. Below the maximum gain. fat fish showed a slightly better feed conversion. It is likely, that C. gariepinus regulates its maximum feed intake, besides by lipostatic mechanisms, also by glucostatic mechanisms, because the maximum feed intake levels of a carbohydrate rich diet $(54 \%)$ were lower than the maximum intake levels of a low carbohydrate diet. The implications of 
these finding are of great practical value. The production results can be influenced by changing the biomass composition of the fish through different feeding strategies or diet compositions.

Finally, the model was used to calculate the performance of $\underline{c}$. gariepinus, fed with differently formulated diets. The output of the model was compared with the results of an experiment were C. gariepinus was fed with diets containing different protein sources of plant and animal origin. The model is suited to predict the effect of nutrient supply on growth and growth composition of $\underline{C}$. gariepinus. For feed formulation purposes it seems possible to calculate a ranking order of different protein ingredients to be included in the fish diet.

Limitations of the model are found for the prediction of growth at high feed intake levels. Emphasis must be given to find adequate relations for feed intake regulation at the upper limits of growth and/or feed intake, because the model is very sensitive for changes in the maximum feed intake level.

The model can be easily adopted for simulating growth of other fish species. Other possible applications are research and teaching on the principles of fish growth and nutrition, development and evaluation of new diets for various production methods and, in combination with a model of the physical culture system, economic analysis of real farm results. 
SAMENVATTING

In het begin van de zeventiger jaren is in Afrika getracht locale vissoorten te vinden, die gebruikt zouden kunnen worden in de visteelt. Een van de meest veelbelovende kandidaten was de Afrikaanse meerval. Clarias gariepinus (Burchell 1822). Het is een alleseter, hetgeen een grote variatie aan mogelijke voederbestandelen betekent. Bovendien kan de vis bij de ademaling voor een gedeelte zuurstof rechtstreeks uit de lucht gebruiken. De zuurstof concentratie in het water zelf is daarom nauwelijks een beperkende factor. Om deze reden kan de soort in hoge dichtheden gehouden worden.

Voor iedere soort geldt dat voor het ontwikkelen van basis teeltvoorschriften, de verschillende fasen in het teeltproces uitgewerkt moeten worden. On van een betrouwbare pootvis voorziening verzekerd te zijn dienen geschikte voortplantingsmethoden vastgesteld te worden. Vervolgens is het belangrijkste aandachtsveld het grootbrengen van de pootvisjes tot consumptiegewicht.

Een belangrijke vraag bij het afmesten van de vis is "hoeveel en wat dient er gevoerd te worden". De hoeveelheid en de samenstelling van het voer hebben een uitgesproken effect op de groeisnelheid en de voederconversie. Het omzettingsproces van voernutriënten in visbiomassa wordt beïnvloed door een aantal diereigen factoren, zoals lichaamsgewicht of ontwikkelingsstadium en omgevingsfactoren als watertemperatuur en waterkwaliteit. Er moeten veel experimenten gedaan worden om de dosis-respons relatie tussen hoeveelheid aangeboden voer en de gewichtstoename van een vissoort vast te stellen voor verschillende gewichtsklassen, voersamenstellingen en temperaturen. Het ontwikkelen van een groeimodel, gebaseerd op de verschillende fysiologische processen in het dier, kan deze grote inspanning wellicht verminderen.

Het onderzoek, beschreven in dit proefschrift, is dan ook gericht op het ontwikkelen van een verklarend groeimodel, waarin de kennis omtrent de invloeden van de verschillende factoren op het 
groeiproces bij elkaar gebracht wordt. De kwantitatieve vergelijkingen in het model beschrijuen de processen die plaatsvinden op het onderliggende integratieniveau van de groei: de intermediaire stofwisseling en de biochemie. De vergelijkingen in het model geven het begrip en de kennis van de relaties weer.

Het simuleren gebeurt volgens de toestandsvariabele benadering. bijvoorbeeld een vis van $30 \mathrm{~g}$ (begintoestand) moet groeien naar 100 g (eindtoestand). De snelheden, waarmee de veranderingen plaatsvinden, worden berekend door de hele benodigde tijdsperiode op te delen in kleine tijdsstappen. De toestand van het systeem op elk moment kan vervolgens berekend worden door integratje over de kleine tijdsstappen uitgaande van de begintoestand en de veranderingssnelheden per tijdsstap.

De modelberekeningen starten met de opgenomen hoeveelheid nutriönten. De verteringssnelheid van de verschillende nutriënten hangt af van de eetsnelheid, de voersamenstelling en de verteringsefficiëntie. De hieruit voortkomende aminozuren, vetzuren en monosachariden (glucose) zijn de bouwstenen voor de biosynthese van de te vormen biomassa. Het biosynthese proces hangt naast de samenstelling van de verteerde nutriënten, af van de samenstelling van de reeds bestaande biomassa. Het glycogeen gehalte van visbiomassa is erg laag, daarom is aangenomen dat vetzuren en glucose ongezet worden in biomassa vet. De aminozuren worden gebruikt voor de biosynthese van lichaamseiwit. Ondat de vis zijn lichaamssamenstelling binnen bepaalde grenzen moet houden, zullen, afhankelijk van de voersamenstelling, meer of minder aminozuren via gluconeogenese voor andere doeleinden gebruikt worden.

Gebruikmakend van de biochemische wegen voor biosynthese en andere stofwisselingsprocessen, zoals in de literatuur beschreven. kan een moleculaire reactievergelijking opgesteld worden. Deze geeft het substraat dat nodig is voor de vorming van een specifiek eindprodukt. De reactievergelijkingen bevatten meestal ATP of andere recirculerende tussenproducten die gebruikt worden bij energetische omzettingsprocessen. De eindvergelijking voor het meest gecompliceerde substraat en eindprodukt stelt de efficiëntst mogelijke omzetting voor, gegeven het biochemisch mechanisme. De eindvergelijking is gemakkelijk om te zetten in gewichtconversies voor beschikbare substraten en gevormde eindprodukten. 
Niet alle visbiomassa, die via biosynthese gevormd wordt, is daadwerkelijk een gewichtstoename omdat een gedeelte van de biomassa tegelijkertijd afgebroken wordt voor de ademhaling. De ademhaling wordt bepaald door de snelheid waarmee de stofwisseling zich afspeelt. Het is de som van de routine stofwisseling onder vastende omstandigheden, de stofwisseling voor voeropname en voerverwerking en de stofwisseling voor de biosynthese van biomassa.

De verhouding waarin lichaamseiwit en lichaamsvet geoxideerd worden bij de ademhaling is afhankelijk gesteld van de lichaamssamenstelling. Daarmee wordt een onrealistische lichaamssamenstelling voorkomen. De verandering in hoeveelheid van de verschillende lichaamsbestandelen wordt berekend wit het verschil van de biosynthese en de afbraak benodigd voor de ademhaling. Als de eiwitgroei bekend is, wordt de versgewichtstoename berekend uit een relatie tussen lichaamsgewicht en eiwitgehalte. De vetgroei heeft in het model effect op de lichaamssamenstelling. Het vet en het waterpercentage van visbiomassa zijn sterk negatief gecorreleerd.

Consumptie van voer door de vis wordt bepaald door het dagelijks voer rantsoen. Ondat bij hoge voerniveau's een verschil kan bestaan tussen de hoeveelheid geconsumeerd en hoeveelheid aangeboden voer. is een relatie tussen maximale consumptie en visgewicht bij verschillende temperaturen ingebouwd in het model. Hiermee kan de gewichtstoename bij hoge voedergiften gelimiteerd worden. In het model wordt de maximale voeropname tevens gereguleerd door de samenstelling van zowel vis als voer. Vette vissen kunnen maximaal minder voer consumeren dan magere vissen van hetzelfde gewicht. Een vis 2 al ook minder eten van een koolhydraat rijk dieet.

Als input voor de berekening zijn nodig: gewicht en vetgehalte van de vis, hoeveelheid en samenstelling van het voer en de watertemperatuur. Met het model kunnen ondermeer berekend worden: de versgewichtstoename, eiwit en vetgroei, zuurstofconsumptie en koolzuur en ammonia productie.

Gedurende de modelontwikkeling is het model getest door de uitkomsten te vergelijken met experimentele gegevens, die niet bij het calibreren gebruikt zijn.

In de eerste plaats is een vergelijking gemaakt met de resultaten van een proef waarbij eeen soort voer op 5 verschillende voer- 
niveau's aangeboden is aan verschillende gewichtsklassen van $C$. gariepinus bij 3 temperaturen. Een tweede vergelijking werd gemaakt met de resultaten van een experiment waarbij voeders met verschillende samenstellingen aangeboden werden. De modelschattingen voor de effecten van voerniveau, voersamenstelling (in het bijzonder eiwit en vet gehalte) en de temperatuur op groei en groeisamenstelling kwamen redelijk goed overeen met de experimentele gegevens. De testresultaten geven aan, dat $\underline{C}$. gariepinus de voernutriënten benut met een biochemisch maximale efficiëntie. Wel kwam eruit naar voren dat de maximale voeropname waarschijnlijk mede gereguleerd wordt door het vetgehalte van de vis biomassa.Omdat hierover geen gegevens voorhanden waren, is een experiment uitgevoerd on het effect van de lichaamssamenstelling op de groef en de voeropname te bepalen. De resultaten bevestigden het vermoeden. Als eenzelfde dieet aan een vette of een magere vis gevoerd wordt, dan resulteert dit in een hogere maximale gewichtstoename van de magere vis, ondat deze meer van het voer opneemt. Bij voerniveaus beneden de maximale gewichtstoename, was de voederconversie van vette vissen jets beter. Het lijkt erop, dat $\underline{C}$. gariepinus naast via een lipostatisch mechanisme, zijn voeropnanmede reguleert via een glucostatisch mechanisme. De maximale voeropname van een koolhydraat-rijk voer (54\%) was namelijk lager dan die van een koolhydraat-arm dieet. Voor de praktijk zijn deze resultaten van groot belang. Immers de teeltresultaten worden beinvloed door het voederschema, de samenstelling van het voer en de tengevolge van het geven van het voer veranderende chemisch samenstelling van de vis zelf.

Als laatste is het model gebruikt om te berekenen hoe snel $C_{\text {. }}$ gariepinus kan groeien op een aantal verschillend geformuleerde voeders. De uitkonsten van het model zijn vergeleken met de resultaten van een experiment, waarbij $\underline{C}$. gariepinus gevoerd werd met voeders, die verschillende eiwitten van plantaardige of dierlijke oorsprong bevatten. Het model blijkt geschikt te zijn om het effect van nutriënten aanbod op groei en groeisamenstelling van $\underline{C}$. gariepinus tẹ simuleren. Voor voerformulerings doeleinden lijkt het mogelijk met het model een rangorde in geschiktheid vast te stellen voor verschillende eiwitingrediënten die in het voer opgenomen kunnen worden.

De beperkingen van het model zijn te vinden bij de voorspelling van de groei bij de hoogste voerniveau's. In de toekomst moet 
aandacht besteed worden, aan het vinden van geschikte vergelijkingen voor de voeropname regulering bij de bovengrenzen van groei en voeropname. Het model is namelijk erg gevoelig voor veranderingen van de maximale voeropname.

Het model kan gemakkelijk worden aangepast en gebruikt voor de simulatie van groei van andere vissoorten. Een andere mogelijk toepassingsterrein is onderzoek en onderwijs op het gebied van voeding en groei van vissen. In aansluiting op onderzoek kunnen nieuwe voeders ten behoeve van verschillende teeltmethoden ontwikkeld en geëvalueerd worden. Een economische analyse van praktijkgegevens lijkt mogelijk als dit model als module van een groter model voor het hele teeltsysteem gebruikt wordt. 
Marcel Machiels, geboren op 25 april 1953 te Maastricht. behaalde in 1969 het getuigschrift 3-jaar HBS aan het Hendrik van Veldeke College te Maastricht. In 1969 begon hij met een opleiding voor analist aan de Zuidlimburgse Laboratorium School te Sittard. Het diploma (HBO-b, analytisch-chenisch) behaalde hij in 1973. Na vervulling van de militaire dienstplicht trad hij in 1975 in dienst bij het Rijks Landbouw Proefstation te Maastricht. In hetzelfde jaar begon hij met zijn studie in de richting Tropische Plantenteelt aan de Landbouwhogeschool te Wageningen. In 1982 behaalde hij het ingenieursdiploma met als hoofdvakken de Tropische Plantenteelt en de Visteelt en Visserij en als bijvak de Theoretische Teeltkunde. Vanaf 1982 is hij werkzaam bij de vakgroep Visteelt en Visserij van de Landbouwuniversiteit te Wageningen waar 0. a dit proefschrift is bewerkt. 